LUIZ CARLOS ZANGRANDE VIEIRA

\title{
Os mecanismos de formação e os efeitos clínicos de duas deleções cromossômicas: $\operatorname{del}(X)(p 11.23)$ e del $(8)(p 23.1)$
}

São Paulo

2007 
LUIZ CARLOS ZANGRANDE VIEIRA

\section{Os mecanismos de formação e os efeitos clínicos de duas deleções cromossômicas: $\operatorname{del}(\mathrm{X})(\mathrm{p11.23}) \mathrm{e} \operatorname{del}(\mathbf{8})(\mathrm{p} 23.1)$}

Dissertação apresentada ao Instituto de Biociências da Universidade de São Paulo, para a obtenção de Título de Mestre em Ciências, na Área de Biologia/Genética.

Orientadora:

Dra. Angela M. Vianna Morgante

São Paulo

2007 


\section{Vieira, Luiz Carlos Zangrande}

Os mecanismos de formação e os efeitos clínicos de duas deleções cromossômicas: $\operatorname{del}(\mathrm{X})(\mathrm{p} 11.23)$ e $\operatorname{del}(8)(\mathrm{p} 23.1)$. $74 \mathrm{pp}$.

Dissertação (Mestrado) - Instituto de Biociências da Universidade de São Paulo. Departamento de Genética e Biologia Evolutiva.

1. Rearranjos Cromossômicos Estruturais. 2. Pontos de Quebra Cromossômicos. 3. Deficiência Mental Sindrômica.

Universidade de São Paulo. Instituto de Biociências. Departamento de Genética e Biologia Evolutiva.

\section{Comissão Julgadora:}

$\operatorname{Prof}(a) . \operatorname{Dr}(a)$.

Prof(a). Dr(a).

Profa. Dra. Angela M. Vianna Morgante

Orientadora 
Este trabalho foi realizado com auxílios financeiros do CNPq e da FAPESP concedidos à orientadora e ao aluno.

Created with novaPDF Printer (www.novaPDF.com). Please register to remove this message. 
À minha família.

Created with novaPDF Printer (www.novaPDF.com). Please register to remove this message. 
Todo homem, por natureza, quer saber.

Aristóteles

Created with novaPDF Printer (www.novaPDF.com). Please register to remove this message. 


\section{AGRADECIMENTOS}

A Angela Morgante, pela orientação, pela oportunidade e pelo estímulo.

Ao Prof. Paulo Otto, Chefe do Departamento de Genética e Biologia Evolutiva, por proporcionar um ambiente de trabalho descontraído e pela avaliação clínica dos pacientes.

A Sylvie Antonini, pelos primeiros ensinamentos, paciência e co-orientação.

Aos pacientes e seus familiares, pela colaboração com o projeto.

A Ligia, Mara, Fátima, Maraisa e Paulo Rogério, pelas brincadeiras, bom humor de cada dia e pelo apoio técnico.

A Carla Rosenberg, Ana Cristina Victorino Krepischi dos Santos, Luciana Amaral Haddad e Regina Celia Mingroni Netto pelas colaborações e sugestões.

A Rafaella, Jihane, Carola e Karina, pelo importante auxílio na execução da parte molecular.

Aos colegas e amigos do Laboratório de Genética Humana e do Departamento de Genética e Biologia Evolutiva, que ajudaram a superar as dificuldades, tornando agradável o passar dos dias: Adriano, Ana Lúcia, Ana Carla, Ana Cristina, Andrea, Betânia, Carola, Cláudia(s), Cris, Daniel, Deborah, Eliete, Fátima, Flavia, Fernando, Mara, Maraisa, Mariana, Nathália, Jacaré, Joana, Juliana, Karen, Karina, Larissa, Ligia, Lilian, Luciana, Rafaella, Raquel, Ronaldo, Sarita, Sílvia, Sylvie, Teresa e Virgínia.

À turma que, quase sempre, me acompanhava nas peregrinações ao "bandejão": Fortaleza, Leandro, Marcella, Nathália, Polonês, Sandra e Vanessa.

A todos os outros amigos, que, apesar de não terem sido citados, também tiveram importância ao longo desse trabalho.

A Natália G. Barros, pela compreensão, atenção e incentivo dados a todo momento.

À minha família, por toda confiança depositada e por todas as formas de apoio possíveis. 


\section{ÍNDICE}

\section{INTRODUÇÃO}

I.1. A FORMAÇÃO DAS ALTERAÇÕES CROMOSSÔMICAS ESTRUTURAIS 9

I.2. AS ALTERAÇÕES CROMOSSÔMICAS INDICANDO GENES

CANDIDATOS A QUADROS CLÍNICOS

I.3. AS VARIANTES ESTRUTURAIS, SEUS EFEITOS CLÍNICOS E A

PREDISPOSIÇÃO A REARRANJOS

\section{OBJETIVOS}

\section{PACIENTES E MÉTODOS}

III.1. PACIENTES

III.1.1. PACIENTE $1 \quad 20$

III.1.2. PACIENTE 2

III.2. MÉTODOS

III.2.1. ANÁLISE CROMOSSÔMICA $\quad 23$

III.2.1.1. Preparações cromossômicas 23

III.2.1.2. Hibridação in situ fluorescente (FISH) 23

III.2.2. ANÁLISES DO DNA 25

III.2.2.1 Extração do DNA 25

III.2.2.2. Análise de loci de microssatélites $\quad 25$

III.2.2.3. Seqüenciamento do DNA 26

III.2.2.4. Southern blotting 27

IV. RESULTADOS E DISCUSSÃO

IV.1. DELEÇÃO DO CROMOSSOMO X 29

IV.1.1. MAPEAMENTO DOS PONTOS DE QUEBRA 29

IV.1.2. A DELEÇÃO E O QUADRO CLÍNICO 39

IV.2. DELEÇÃO DO CROMOSSOMO 8

IV.2.1. MAPEAMENTO DOS PONTOS DE QUEBRA $\quad 45$

IV.2.2. A ORIGEM PARENTAL DA DELEÇÃO

IV.2.3. OS POLIMORFISMOS E A FORMAÇÃO DOS REARRANJOS
DO BRAÇO CURTO DO CROMOSSOMO 8

IV.2.4. O QUADRO CLÍNICO DE DELEÇÕES DO BRAÇO CURTO DO CROMOSSOMO 8

V.SUMÁRIO E CONCLUSÕES

Deleção do braço curto do cromossomo X $\quad 69$

Deleção do braço curto do cromossomo 8

VI. ABSTRACT

VII. REFERÊNCIAS BIBLIOGRÁFICAS

BANCOS DE DADOS ELETRÔNICOS E OUTROS RECURSOS DA 82

INTERNET 


\section{INTRODUÇÃ̃O}

As anomalias cromossômicas são encontradas em cerca de seis em cada 1.000 recém-nascidos e em $25 \%$ dos abortos e natimortos, sendo de 50 a $60 \%$ a freqüência nos abortamentos de primeiro trimestre. As anomalias cromossômicas mais freqüentes são as numéricas, porém os rearranjos cromossômicos estruturais equilibrados são detectados em cerca de 1:500 indivíduos na população geral e os rearranjos estruturais não equilibrados correspondem a cerca de 3\% das anormalidades cromossômicas (revisão em Jacobs e Hassold, 1986).

\section{I.1. A FORMACÃO DAS ALTERACÕES CROMOSSÔMICAS ESTRUTURAIS}

O dano ao DNA provoca a ativação de processos de reparo controlados geneticamente. As células normais são capazes de reparar danos com fidelidade ou introduzir erros durante o reparo, de acordo com o tipo de lesão e do mecanismo utilizado para o reparo (revisão em Moustacchi, 2000). As quebras na dupla fita do DNA (Double Strand Break - DSB), sejam induzidas por agentes externos (radiação ionizante, por exemplo) ou resultantes de processos celulares normais, podem ser retificadas na célula eucarionte por duas principais vias de reparo: a recombinação homóloga (Homologous Recombination - HR) ou a junção de extremidades não homólogas (Non-Homologous End Joining - NHEJ) (revisão em Moustacchi, 2000; Haber, 2000).

Ocorrendo mais de uma quebra em uma mesma célula, o reparo por NHEJ pode unir extremidades não contíguas, com adição ou com perda de seqüências, causando rearranjos estruturais. O mecanismo de NHEJ foi evidenciado, por exemplo, no caso de translocações entre o cromossomo $\mathrm{X}$ e um autossomo, em que não havia homologia extensa entre os segmentos envolvidos e se detectaram pequenas deleções, duplicações e inserções nos pontos de quebra e junção (van Bakel et al., 1995; Vianna-Morgante et al., 2004). Os rearranjos estruturais podem ainda se originar do reparo por recombinação homóloga, quando são utilizadas seqüências homólogas ectópicas, como substrato para a recombinação. A análise das sequiências presentes nos pontos de quebra de rearranjos e a determinação do grau de homologia entre elas podem fornecer 
indicações sobre a contribuição dos diferentes mecanismos de reparo para sua formação (revisão em Haber, 2000).

Com o avanço das técnicas moleculares, foi possível identificar que determinadas regiões do genoma possuem características estruturais que as predispõem a participar de rearranjos. Doenças causadas por tais rearranjos foram denominadas por Lupski (1998) de doenças genômicas, contrastando com o mecanismo clássico para doença genética, em que um fenótipo anormal é principalmente originado por mutações de ponto. Por exemplo, em casos de genes sensíveis à dosagem flanqueados por repetições orientadas em tandem, se ocorrer recombinação não alélica entre as repetições flanqueadoras, os genes localizados entre as repetições podem ser deletados (haploinsuficiência) ou duplicados (aumento de dosagem). No caso de genes homólogos dispostos em tandem, podem surgir genes híbridos recombinantes, com diferentes propriedades. Se a recombinação ocorre entre repetições invertidas e uma cópia da repetição está localizada dentro de um gene, o resultado é uma inversão que inativa o gene.

Portanto, na HR, o tipo de seqüência utilizada como molde para o reparo define se o reparo será conservador ou se introduzirá erros. Quando a seqüência homóloga da cromátide irmã é o molde para o reparo, não há erros. No caso de a seqüência molde ser a do cromossomo homólogo, pode ocorrer conversão gênica. O molde escolhido pode, entretanto, ser uma seqüência homóloga, porém não alélica (Non-Allelic Homologous Recombination - NAHR), o que resulta em rearranjos cromossômicos. Por exemplo, está documentada a participação de elementos repetidos Alu e LINE-1 na origem de rearranjos cromossômicos, a partir de reparo por NAHR. É o caso das duplicações parciais do gene ALL1 na leucemia mielóide aguda, que resultam da recombinação entre seqüências Alu nos introns 1 e 6 desse gene (Strout et al., 1998).

Já se demonstrou que alterações cromossômicas constitucionais com alta recorrência, que condicionam diversas síndromes, resultam de NAHR entre repetições de baixo número de cópias (Low Copy Repeats - LCR), que podem incluir genes/pseudogenes e seqüências repetidas diversas, em tandem ou invertidas (Shaw e Lupski, 2004). Essas alterações são principalmente duplicações e deleções, geralmente não detectáveis nas análises citogenéticas de rotina. Esse é, por exemplo, o mecanismo que origina a microdeleção de cerca de $3,7 \mathrm{MB}$ em 17p11.2, presente na maioria dos pacientes com a síndrome de Smith-Magenis. Os segmentos de junção correspondem à fusão de LCR que ladeiam o segmento deletado. Essas mesmas LCR estão envolvidas 
na origem da microduplicação correspondente à deleção, como esperado num evento de NAHR (revisão em Lupski, 2003).

As LCR têm entre 10 e $500 \mathrm{~Kb}$ de extensão, costumam compartilhar mais de 95\% de identidade (Stankiewicz et al., 2003) e compreendem de 5\% a 10\% do genoma (Bailey et al., 2001). As NAHR entre duas LCR nem sempre ocorrem num mesmo ponto dentro delas, mas o rearranjo resulta em alterações de dosagem relacionadas a uma determinada doença genômica (Stankiewicz e Lupski, 2002). Apesar dos longos trechos de identidade de seqüência entre cópias de LCR, a recombinação ocorre em posições preferenciais. Assim, em doenças como Charcot-Marie-Tooth do tipo 1A (CMT1A), neurofribromatose do tipo 1 (NF1) e síndrome Williams-Beuren (WBS) ocorrem "hotspots" que variam de 557 pb a $12 \mathrm{~Kb}$ e que representam apenas $2 \%-13 \%$ da seqüência de identidade entre as LCR (revisão em Shaw et al., 2004). É interessante que, em células de mamíferos, 200 pb parece ser o comprimento mínimo ininterrupto com identidade de sequiência requerida para iniciar a recombinação homóloga na meiose (revisão em Lukacsovich e Waldman, 1999).

Em algumas situações, foi mostrado que rearranjos cromossômicos afetando segmentos cromossômicos relativamente longos podem ser causados por NAHR. De forma geral, as translocações recíprocas são únicas quanto aos cromossomos participantes e os pontos de quebra. Sendo assim, a maioria é muito pouco conhecida em termos de mecanismos de formação. Há, entretanto, uma certa predominância de translocações envolvendo certos segmentos de alguns cromossomos, sugerindo a presença de homologia entre os diferentes cromossomos rearranjados. A t(11;22) é um rearranjo conhecido por sua recorrência e por ter um fragmento de junção semelhante em diferentes afetados. Nesse caso, a quebra no braço longo do cromossomo 22 foi localizada na LCR-B e no braço longo do cromossomo 11, em uma região repetitiva rica em AT. A LCR-B também tem repetições AT, o que sugere a ocorrência de recombinações entre esses segmentos (Shaikh et al., 2001). Esse ponto de quebra na LCR-B também foi identificado em outras translocações: $t(17 ; 22)(q 11.2 ; q 11.2)$, $\mathrm{t}(1 ; 22)(\mathrm{p} 21.2 ; \mathrm{q} 11.2)$ e $\mathrm{t}(4 ; 22)(\mathrm{q} 35.1 ; \mathrm{q} 11.2)$. A maioria das quebras em 22q11 ocorreu no centro de uma repetição palindrômica rica em AT de 595 pb de comprimento. As quebras nos outros cromossomos envolvidos nessas translocações (11q23, 17q11.2, 1p21.2, 4q35.1) também ocorrem no centro de seqüências repetidas invertidas. Essas observações sugerem que a estrutura secundária do DNA na forma de grampos é a base do rearranjo (revisão em Gotter et al., 2007). Uma inversão de um segmento de $3 \mathrm{Mb}$ 
em 22q11.21, tipicamente deletado em pacientes com a síndrome da deleção 22q11.2, parece ser o evento que precedeu uma translocação 46,XY,t(8;22)(q24.13;q11.21), com o ponto de quebra recorrente em $22 q$ e o outro em uma repetição rica em AT de $8 q$ (Gotter et al., 2007).

No caso das translocações Robertsonianas, o emparelhamento de seqüências repetitivas pericentroméricas, que teriam homologia em cromossomos acrocêntricos, propiciaria a transferência de braços cromossômicos pela troca entre seqüências emparelhadas em disposição invertida ou por uma recombinação em U (Shaffer e Lupski, 2000).

Muitos dos estudos de mapeamento de pontos de quebra de aberrações cromossômicas concentram-se em "alterações genômicas recorrentes". Há, porém, alguns estudos cujo foco foram alterações cromossômicas que afetam grandes blocos cromossômicos, buscando a caracterização mais precisa desses rearranjos e a determinação de seus mecanismos de origem.

Em 1996, Floridia et al. estudaram 16 casos de duplicação invertida do braço curto do cromossomo 8 [invdup(8p)]. A fim de identificar os segmentos duplicados, os autores utilizaram FISH, análise de polimorfismos de DNA por PCR e análise quantitativa por Southern blotting. Os rearranjos ocorreram sempre entre cromossomos homólogos e os pontos de quebra na extremidade distal do braço curto do cromossomo 8 foram localizados nos mesmos segmentos cromossômicos. Os autores sugeriram a presença, nesses segmentos, de seqüências repetidas com orientação invertida, cujo emparelhamento na meiose favoreceria a ocorrência de recombinação, levando à formação de dicêntricos. Quebras centroméricas originariam os cromossomos 8 com duplicação invertida.

Antonini et al. (2002) estudaram dois casos de duplicação do braço curto do cromossomo 3, identificados por meio do padrão de bandas G. A investigação por FISH permitiu o mapeamento dos pontos de quebra em segmentos contidos em YAC ou em intervalos delimitados por tais sondas. A análise de microssatélites por PCR indicou que ambos os rearranjos ocorreram entre cromátides irmãs dos cromossomos paternos.

Krepischi-Santos e Vianna-Morgante (2003) mapearam os pontos de quebra em três casos de duplicação do braço curto do cromossomo 9, utilizando FISH e a análise de polimorfismos de DNA. Nos três casos, a duplicação abrangia quase todo o braço curto do cromossomo 9, tendo sido demonstrado que a duplicação era direta em dois casos e invertida no outro. Nos dois casos de dirdup(9p), o ponto de quebra distal foi 
localizado na região subtelomérica, enquanto que o ponto de quebra proximal foi localizado na região pericentromérica. $\mathrm{O}$ estudo de polimorfismos de DNA indicou que esses rearranjos ocorreram na meiose materna. $\mathrm{Na}$ invdup(9p), o ponto de quebra proximal foi mapeado nas sequiências centroméricas, enquanto que o ponto de quebra distal foi localizado num segmento proximal à região subtelomérica, que não estava presente no cromossomo duplicado. A análise de polimorfismos de DNA apontou a origem paterna e pós-zigótica do rearranjo. As autoras sugerem que os rearranjos teriam se originado de recombinação entre seqüências repetitivas com homologia presentes nas regiões pericentromérica e subtelomérica do cromossomo 9.

Rearranjos aparentemente equilibrados, associados a alterações fenotípicas, podem refletir uma complexidade adicional no mecanismo de formação. Em uma amostragem de dez casos de translocações constitucionais aparentemente equilibradas em pacientes com fenótipo anormal, Gribble et al. (2005) detectaram rearranjos complexos crípticos (CCR - Cryptic Complex Chromosomal Rearrangements) em seis casos. Mais quatro casos como esses foram descritos posteriormente por Ciccone et al. (2005). Uma deleção em portadora de translocação aparentemente equilibrada entre três cromossomos foi detectada por CGH-array por Rosenberg et al. (2005).

São desconhecidos os mecanismos de formação e as seqüências envolvidas na maior parte dos rearranjos cromossômicos não recorrentes. A caracterização dessas seqüências pode ajudar a compreender melhor os mecanismos de origem das alterações cromossômicas. O aprimoramento das técnicas citogenéticas em associação com a análise do DNA e com o crescente conhecimento da sequiência e da arquitetura do genoma humano tem permitido abordar tais aspectos da formação dos rearranjos cromossômicos, levando aos mecanismos subjacentes à sua formação. Ao mesmo tempo, com a caracterização desses rearranjos busca-se entender seus efeitos clínicos e chegar à identificação de genes relacionados às alterações fenotípicas.

\section{I.2. AS ALTERACÕES CROMOSSÔMICAS INDICANDO GENES CANDIDATOS A QUADROS CLÍNICOS}

Vários estudos têm relacionado genes a determinados quadros clínicos a partir de alterações cromossômicas presentes nos afetados. Os rearranjos equilibrados, como as translocações recíprocas, são particularmente informativos, pois oferecem a oportunidade de se identificarem genes candidatos alterados pelas quebras 
cromossômicas, como mostram os vários relatos da literatura. É ilustrativo o caso da paciente com hipotonia e deficiência mental grave, portadora de translocação $\mathrm{t}(\mathrm{X} ; 3)(\mathrm{p} 11.2 ; \mathrm{p} 25)$ de novo descrito por Endris et al. (2002). O ponto de quebra no cromossomo X estava localizado fora de região codificadora, porém demonstrou-se que o gene MEGAP (MEntal disorder-associated GAP protein), mapeado em 3p25, fora interrompido pelo rearranjo. Os autores estudaram 11 pacientes com alterações terminais em $3 \mathrm{p}$ e observaram deleção de $M E G A P$ em todos os pacientes com deficiência mental grave. O único paciente portador de deleção do braço curto do $3 \mathrm{em}$ que o gene estava presente tinha função cognitiva normal, demonstrando que a perda do gene $M E G A P$ é crucial para o retardo mental nessa síndrome de deleção cromosômica. $M E G A P$ é altamente expresso em tecido cerebral fetal e adulto, especificamente nos neurônios do hipocampo e do córtex, estruturas conhecidas por desempenhar funções principais na mais alta função cognitiva, aprendizado e memória. Participa ainda da regulação da migração neuronal e da ramificação axonal, que são importantes para a função cognitiva normal.

Já os rearranjos cromossômicos não equilibrados, com segmentos deletados e duplicados que podem incluir vários genes, não são o ideal para fazer essa associação genótipo-fenótipo. Mesmo assim, há possibilidade de se chegar a genes candidatos, como mostra, por exemplo, a associação do gene CRELD1 com defeitos do septo ventricular (AVSD), que são malformações cardiovasculares relativamente comuns. A ocorrência de AVSD em pacientes com deleções do braço curto do cromossomo 3 levou à identificação de um locus, denominado AVSD2 na região deletada. Robinson et al. (2003) caracterizaram a molécula de adesão celular CRELD1, como sendo o produto de gene candidato para o locus AVSD2 e tendo sido identificadas mutações em heterozigose do gene CRELD1 (Cysteine-Rich Protein With EGF-Like Domains 1) em 6\% dos indivíduos com AVSD.

Com a aplicação da hibridação genômica comparativa utilizando-se arrays (CGH-array), desequilíbrios cromossômicos que abrangem menos de $1 \mathrm{Mb}$ passaram a ser detectados, aumentando assim a chance de se identificarem genes relacionados aos quadros clínicos. Por exemplo, recentemente, os genes MAPT (Microtubule-Associated Protein $\boldsymbol{T} a u$; mutações antes associadas com a demência fronto-temporal associada a parkinsonismo) e CRHR1 (Corticotropin-Releasing Hormone Receptor 1) foram associados com atraso do desenvolvimento neuropsicomotor por estarem contidos nas microdeleções de 500 -600 kb em 17q21.3, detectadas em afetados (Varela et al., 2006; 
Koolen et al., 2006; Shaw-Smith et al., 2006). Entretanto, a relação desses microdesequilíbrios cromossômicos com o fenótipo pode ser complexa, como discutiremos a seguir.

\section{I.3. AS VARIANTES ESTRUTURAIS, SEUS EFEITOS CLÍNICOS $E$ A PREDISPOSICÃO A REARRANJOS}

A hibridação genômica comparativa, utilizando arrays (CGH-array) tem evidenciado não somente variações no número de cópias de segmentos cromossômicos em associação com quadros clínicos (Krepischi-Santos et al., 2006; Rosenberg et al., 2006; Sharp et al., 2006), como também variações no número de cópias como polimorfismos na população geral (CNV, Copy Number Variation, ou CNP, Copy Number Polymorphism; Sharp et al., 2005; Redon et al., 2006; Wong et al., 2007).

A relação de microdeleções e microduplicações com o fenótipo clínico pode, entretanto, ser complexa. Microdeleções e duplicações presentes tanto em indivíduos afetados quanto em outros fenotipicamente normais dificultam a associação com os quadros clínicos. Admitir, como causa de alteração fenotípica, apenas rearranjos autossômicos de novo e, quando herdados, somente os ligados ao $\mathrm{X}$, todos não descritos como polimorfismos, é pensar de modo conservador. Mecanismos como expressão de gene recessivo antes coberto, dependência de outras alterações genômicas e mecanismos diversos de penetrância incompleta podem estar atuando para a manifestação clínica ou não de um microrrearranjo (Krepischi-Santos et al., 2006).

Redon et al. (2006) construíram a primeira geração de mapa de CNV do genoma humano com base em um estudo de 270 indivíduos de três continentes. Para a busca por CNV, utilizaram arrays de genotipagem de SNP e CGH-array de clones do genoma humano, cobrindo $360 \mathrm{Mb}$ (12\% do genoma). Detectaram 1447 regiões de CNV, podendo compreender sobreposições, como também ganhos ou perdas adjacentes. Essas CNV contêm centenas de genes, inclusive já relacionados a doenças, e outros elementos funcionais.

Wong et al. (2007) realizaram um screening genômico de pessoas normais e identificaram 3654 CNV em cromossomos autossômicos. Dessas, 800 apareciam com uma freqüência de pelo menos 3\% dentre indivíduos analisados, $77 \%$ das quais ainda não haviam sido descritas. Verificaram também que mais de 1500 genes estavam incluídos nas CNV: genes relacionados aos sentidos (de receptores olfativos, de sabor, 
de visão e de audição), genes que sabidamente variam em número de cópias (grupo sanguíneo RH, amilases e defensinas), genes relacionados a câncer e a doenças multifatoriais (como as doenças de Alzheimer e de Parkinson, doenças coronarianas, obesidade, diabetes, susceptibilidade a dependência de nicotina, propensão à esquizofrenia). A diferença entre os indivíduos mais discrepantes quanto a CNV foi de 9 $\mathrm{Mb}$ (266 loci ou 228 clones de CNV), o que levou à conclusão de que mais de 1,5\% do genoma é tolerante a CNV.

Ullmann et al. (2007) identificaram uma duplicação de 1,5 Mb por CGH-array, flanqueada por LCR, em 16p13, em quatro homens autistas de três famílias não relacionadas, em alguns de seus parentes normais e afetados em graus variáveis. A deleção do mesmo intervalo foi detectada em outros três pacientes com deficiência mental e outras anomalias clínicas. Variações de número de cópias não haviam sido descritas para essa região e nunca havia sido encontrada nos mais de 600 indivíduos analisados. Com isso, os autores sugerem que essas alterações predisporiam ao autismo e à deficiência mental.

Klopocki et al. (2007) identificaram uma deleção de $200 \mathrm{~Kb}$, em 1q21.1, com pontos de quebra ricos em LCR, em todos os 30 pacientes investigados com síndrome de TAR (trombocitopenia hipomegacariocítica e aplasia de rádio), por meio de CGHarray. A deleção, que não foi encontrada em 700 indivíduos controle, foi herdada em $75 \%$ dos casos, em sua maioria de genitores normais. Isso levou os autores a postularem que a síndrome está de fato relacionada à deleção, mas o fenótipo só se manifestaria na presença de alguma modificação adicional, indicando que esses rearranjos podem conferir susceptibilidade e não ser determinísticos.

As variantes estruturais podem servir de substrato para novos rearranjos, tornando seus portadores mais propensos a terem descendentes com alterações cromossômicas patogênicas. Por exemplo, microdeleções podem surgir da recombinação não homóloga entre repetições diretas em um cromossomo. Seqüências repetidas dispostas em sentidos opostos, em um mesmo cromossomo, podem servir de substrato para um rearranjo homólogo não alélico, em um duplo evento de recombinação entre elas, que resulte em inversões pericêntricas ou paracêntricas ou em rearranjos mais complexos, dependendo do número de permutações entre os blocos de alta homologia.

Sharp et al. (2005) definiram 130 regiões dispersas por $2274 \mathrm{Mb}$, potencialmente propensas a rearranjos (hotspots), por estarem flanqueadas por 
repetições que seriam propensas a recombinação. Construíram um microarray para detectar variações de números de cópias por CGH nessas regiões. Em 47 indivíduos normais de quatro continentes, identificaram 119 regiões de $\mathrm{CNV}, 73$ ainda não descritas. Havia uma igual freqüência de duplicações e deleções. Regiões de hotspots chegaram a apresentar um aumento de cópias de até quatro vezes. Em geral, as CNV estavam presentes em todas as populações estudadas, indicando que os eventos de expansão ou retração são recorrentes.

Entre as variantes descritas por Sharp et al. (2005) algumas já eram conhecidas, como é o caso dos aglomerados de genes anti-microbiais de beta-defensinas em 8p23.1 (DEFB4, DEFB103 e DEFB104). Indivíduos da população geral podem apresentar de duas a doze cópias desses genes no genoma diplóide e um cromossomo pode ter de uma a oito cópias; esse polimorfismo pode ser identificado por FISH como uma variação eucromática de 8p23.1 (Hollox et al., 2003). Nesse segmento do cromossomo 8 também existem duas regiões de repetição de receptores olfativos (ORR), distantes 5cM uma da outra, e um em cada quatro indivíduos da população geral é portador de inversão polimórfica do segmento entre essas duas ORR (revisão em Hollox et al., 2003). As inversões polimórficas propiciam o rearranjo t(4;8)(p16;p23). Todas as mães dos pacientes estudados apresentavam tanto a inversão em 4p16 quanto em 8p23, que aparecem na população com uma freqüência de $12,5 \%$ e $26 \%$, respectivamente. Tais inversões ocorrem via NAHR entre LCR com orientações invertidas, que contêm aglomerados gênicos de receptores olfativos, tanto no cromossomo 4 quanto no 8 (revisão em Shaw e Lupski, 2004).

Sharp et al. (2006) detectaram quatro deleções de $600 \mathrm{~Kb}$, em 17q21.31, em pacientes com retardo mental, investigados por microarray. Koolen et al. (2006) e Shaw-Smith et al. (2006) descreveram essa mesma deleção, que pode ser responsável por até $1 \%$ dos casos de deficiência mental (Lupski, 2006). Tais deleções teriam resultado de NAHR associada à inversão polimórfica na população. As inversão está flanqueada por LCR, distantes $\sim 900 \mathrm{~Kb}$ uma da outra e que estão invertidas no haplótipo mais comum (80\%). O outro haplótipo, presente em $20 \%$ da população européia, tem outras LCR orientadas no mesmo sentido, o que predispõe a região a NAHR, gerando uma deleção de $\sim 600 \mathrm{a} \sim 700 \mathrm{~Kb}$, que inclui seis genes, incluindo o $M A P T$.

Nos últimos anos, com o advento dos microarrays, diversas variantes genômicas já foram identificadas como polimorfismos na população geral. Outras foram 
identificadas como causa de fenótipo alterado. Além disso, fica evidente que a associação de determinados quadros fenotípicos com microrrearranjos genômicos pode ser muito complexa e microdeleções e microduplicações genômicas podem não ser determinantes de alterações clínicas, mas conferir susceptibilidade para certas doenças. Dessa forma o estudo dos desequilíbrios genômicos submicroscópicos pode contribuir para a compreensão de mecanismos genéticos envolvidos em doenças de etiologia desconhecida. 


\section{OBJETIVOS}

Neste trabalho, são analisadas duas deleções cromossômicas (uma deleção do cromossomo 8 e outra do cromossomo $\mathrm{X}$ ) detectadas em pacientes com retardo mental associado a sinais, que foram encaminhados, para exame cromossômico e diagnóstico, ao Serviço de Aconselhamento Genético do Laboratório de Genética Humana (IBUSP). Buscando determinar a origem e os mecanismos de formação desses cromossomos alterados e estabelecer a relação entre essas alterações cromossômicas e o fenótipo de seus portadores, este trabalho alia a análise cromossômica por hibridação in situ fluorescente (FISH) com a análise do DNA. 


\section{PACIENTES E MÉTODOS}

\section{III.1. PACIENTES}

Os rearranjos cromossômicos foram detectados em pacientes atendidos no Serviço de Aconselhamento Genético do Laboratório de Genética Humana, LGH (Departamento de Genética e Biologia Evolutiva, Instituto de Biociências da USP). Os responsáveis pelos pacientes deram consentimento, após os devidos esclarecimentos, para que o exame fosse aprofundado em pesquisa. O estudo foi aprovado pelo Comitê de Ética em Pesquisa - Seres Humanos - do Instituto de Biociências da USP (Protocolo $n^{\circ}$ 033/2005). A avaliação clínica dos pacientes foi realizada pela equipe de médicos geneticistas desse serviço e nos serviços de origem, onde foram realizados os exames médicos complementares. Os pacientes foram diagnosticados como portadores das seguintes deleções cromossômicas: 46,XY, del(X)(p11) e 46, XX, del(8)(p23.1).

\section{III.1.1. PACIENTE 1}

Deleção do braço curto do cromossomo $X: 46, X Y, \operatorname{del}(X)(p 11.23)$

O paciente foi encaminhado ao Serviço por apresentar retardo mental profundo associado a microcefalia, baixa estatura e fácies peculiar, tendo apresentado puberdade precoce, por volta dos 9 anos de idade. Foi relatada a ocorrência de outros afetados do sexo masculino com quadro clínico semelhante, que se distribuem na família de acordo com um padrão de herança ligada ao X recessiva (Figura 1).

O probando (IV.26 - Figura 1) nasceu de parto normal a termo, com peso de $2450 \mathrm{~g}$ e comprimento de $43 \mathrm{~cm}$. Era hipotônico. Sentou sem apoio com um ano de idade e andou com 2 anos e 8 meses. Examinado aos 12 anos, apresentava retardo mental profundo, movimentos estereotipados, havia sinais de hipotonia e não falava. Tinha contato visual pobre, aversão ao contato físico e crises de agressão. Sua estatura era de $132 \mathrm{~cm}\left(<3^{\circ}\right.$ percentil $)$; tinha olhos profundos, filtro nasal curto, orelhas grandes em abano e rotadas para trás, pés planos e testículos aumentados. O exame físico sempre foi prejudicado, pois o paciente não cooperava. Aos 16 anos de idade, o perímetro cefálico era de $53 \mathrm{~cm}\left(2^{\circ}\right.$ percentil $)$. O tio materno do probando, igualmente 
afetado, não foi examinado pela equipe médica do Serviço de Aconselhamento Genético do LGH, que pôde apenas avaliar suas fotografias.

O exame cromossômico realizado em linfócitos de sangue periférico após bandamento $G$ não revelou alterações. Foi realizado posteriormente um screening genômico, utilizando CGH-array, que incluía 3.500 alvos (segmentos de DNA humano clonados em BAC) distantes um do outro $1 \mathrm{Mb}$ (Knijnenburg et al., 2004). Este array foi produzido no Centro Médico da Universidade de Leiden, na Holanda, e a análise desse caso foi parte de um estudo colaborativo entre o Centro Médico de Leiden e o Laboratório de Genética Humana (Rosenberg et al., 2006). Foi detectada uma deleção em Xp11, de aproximadamente 2Mb. Esta deleção foi detectada também no tio materno do paciente (III.24 - Figura 1), com quadro clínico semelhante, mas não no tio clinicamente normal (III.26).

\section{III.1.2. PACIENTE 2}

\section{Deleção do braço curto do cromossomo 8: 46, XX, $\operatorname{del}(8)(p 23.1)$}

Em sua consulta ao Serviço de Aconselhamento Genético, a menina, aos seis anos e dois meses de idade, demonstrava dificuldade motora e de aprendizado; era hiperativa. Apresentava estatura de $113 \mathrm{~cm}\left(25^{\circ}\right.$ percentil $)$, peso de $20 \mathrm{Kg}\left(25^{\circ}\right.$ percentil) e perímetro cefálico de $47 \mathrm{~cm}$ (abaixo do $3^{\circ}$ percentil). Ao exame físico apresentou os seguintes sinais: nariz aquilino, desvio de septo nasal, palato alto e estreito, orelhas em abano com hipoplasia de cartilagem e clinodactilia bilateral do $5^{\circ}$ dedo. Tinha hipermetropia. Foi relatada a correção cirúrgica de comunicação interatrial. O pai da criança tinha quadro clínico semelhante, não tendo conseguido afalbetizar-se.

A análise após bandamento GTG mostrou uma deleção do braço curto do cromossomo $8-\operatorname{del}(8)($ p23 $\rightarrow$ pter $)$ - na paciente e em seu pai. A mãe da paciente tem cariótipo normal, assim como seus avós paternos (Figura 2). 


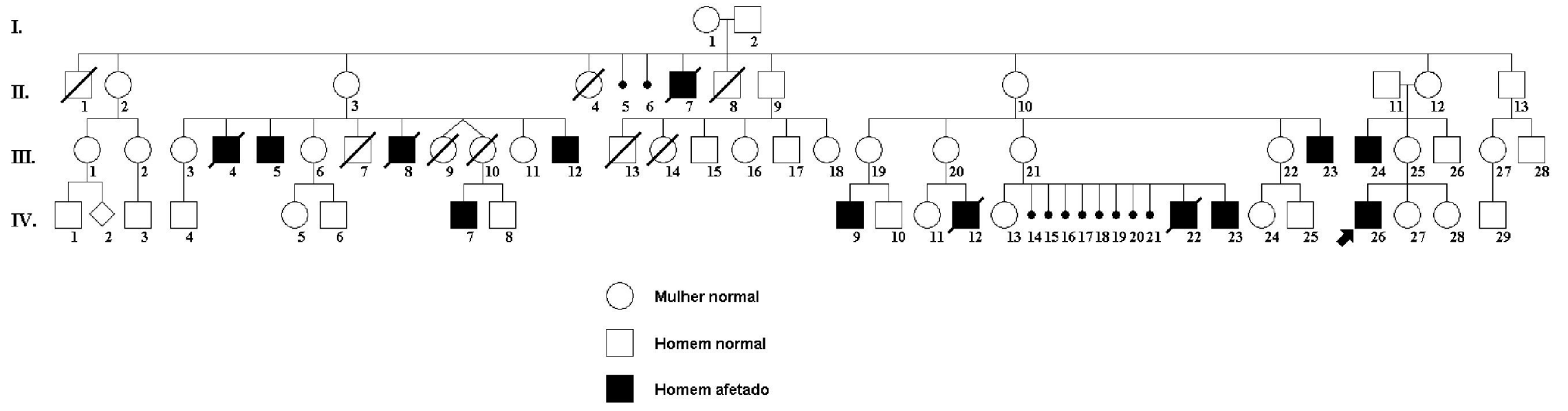

Figura 1. Heredograma do Paciente 1, construído com base em informações dadas por III-25.

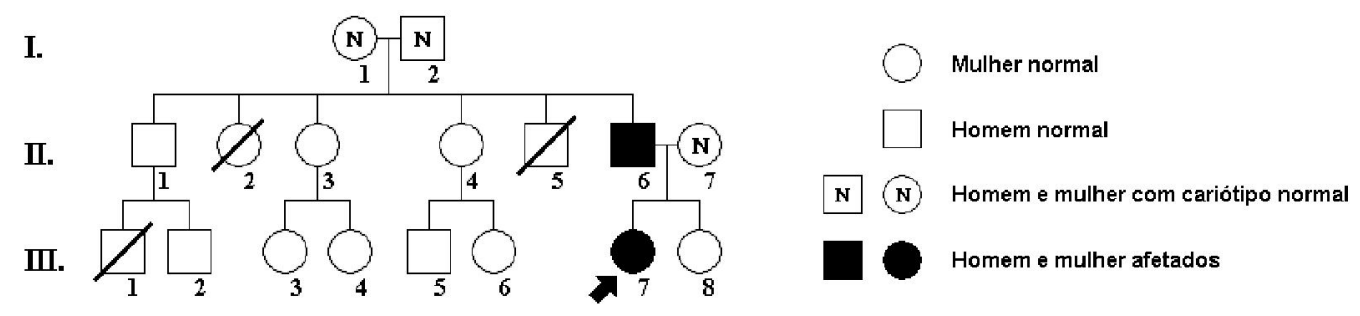

Figura 2. Heredograma da Paciente 2. 


\section{III.2. MÉTODOS}

\section{III.2.1. ANÁLISE CROMOSSÔMICA}

\section{III.2.1.1. Preparações cromossômicas}

As preparações cromossômicas foram obtidas a partir de culturas temporárias de linfócitos de sangue periférico, seguindo as técnicas de rotina do laboratório. Os linfócitos contidos em $0,5 \mathrm{~mL}$ de plasma sanguíneo foram cultivados por $72 \mathrm{~h}$, a $37^{\circ} \mathrm{C}$ em 4,5 mL de meio de cultura TC 199 (Invitrogen, Carlsbad, EUA), complementado com soro fetal bovino 15\% (Invitrogen), L-glutamina 1\% (Sigma, Saint Louis, EUA) e fitohemaglutinina $1 \%$ (Invitrogen). $\mathrm{O}$ tratamento com colchicina (Sigma) na concentração final de $0,0016 \%$ foi realizado nos 40 minutos finais do cultivo. Para a hipotonização, utilizou-se uma solução de $\mathrm{KCl}(0,075 \mathrm{M})$ por 12 minutos a $37^{\circ} \mathrm{C}$ e para a fixação, metanol:ácido acético, 3:1. Parte do material foi conservado a $-20^{\circ} \mathrm{C}$ no fixador e parte foi utilizada na preparação de lâminas, que foram mantidas em estufa a $37^{\circ} \mathrm{C}$, por sete a quinze dias e, então, utilizadas para a aplicação de técnicas de bandamento cromossômico, ou congeladas a $-20^{\circ} \mathrm{C}$ para utilização posterior em experimentos de hibridação in situ.

\section{III.2.1.2. Hibridação in situ fluorescente (FISH)}

Nos experimentos de hibridação in situ fluorescente foram utilizados, como sondas, segmentos cromossômicos clonados em cromossomos artificiais de bactérias (BAC), localizados nas regiões cromossômicas de interesse. As sondas foram selecionadas a partir dos mapas obtidos em bancos de dados: Genome Database (GDB; http://gdbwww.gdb.org), Ensembl (http://www.ensembl.org), National Center for Biotechnology Information (NCBI; http://www.ncbi.nih.gov) e University of California - Santa Cruz - Genome Browser (UCSC; http://genome.ucsc.edu). Foram obtidas do BACPAC Resources, Children's Hospital Oakland Research Institute (CHORI; http://www.chori.org).

As bactérias que continham as sequiências clonadas foram multiplicadas em LB líquido e seletivo (cloranfenicol $20 \mu \mathrm{g} / \mathrm{mL}$ ). A extração das sondas seguiu o protocolo fornecido pelo CHORI (Oakland). A concentração das sondas foi estimada em gel de 
agarose $0,8 \%$ e a marcação feita por nick translation com biotina ou digoxigenina (Biotin-Nick Translation Mix ou Dig-Nick Translation Mix, respectivamente; Roche Applied Science), conforme instruções do fabricante. A supressão das sequiências repetitivas foi feita com $6 \mu \mathrm{g}$ de Cot (Roche) para $250 \mu \mathrm{g}$ de sonda. Para a precipitação do DNA da sonda adicionou-se uma quantidade de acetato de sódio $3 \mathrm{M}$ equivalente a $10 \%$ do volume da reação de marcação e etanol absoluto equivalente a 2,5 vezes desse volume. Após incubação overnight a $-20^{\circ} \mathrm{C}$, procedia-se à centrifugação por 30 minutos a $13000 \mathrm{rpm}$. Após serem precipitadas, as sondas foram re-suspendidas em $12 \mu \mathrm{L}$ de meio de hibridação (formamida $50 \%$ e dextran sulfato $10 \%$, em 2XSSC), em concentrações que variaram de $300-600 \mathrm{ng} / \mu \mathrm{L}$. A desnaturação foi feita a $98^{\circ} \mathrm{C}$ por 10 min, seguida de pré-annealing a $37^{\circ} \mathrm{C}$ por $30 \mathrm{~min}$.

As lâminas das preparações cromossômicas foram armazenadas a $-20^{\circ} \mathrm{C}$. Após o descongelamento, o material foi tratado com RNAse (100 $\mu \mathrm{g} / \mathrm{mL}$ em $2 x \mathrm{xSC})$, por uma hora a $37^{\circ} \mathrm{C}$, seguindo-se três banhos de $2 \mathrm{xSSC}$, desidratação em banhos de etanol e secagem ao ar. Para a desnaturação dos cromossomos, utilizou-se formamida $70 \% \mathrm{em}$ 2xSSC, por 2 min a $73^{\circ} \mathrm{C}$, seguida da desidratação em etanol gelado e secagem ao ar.

A sonda no meio de hibridação foi colocada sobre a lâmina e recoberta com lamínula, incubando-se em câmara úmida a $37^{\circ} \mathrm{C}$ por dois dias. As lâminas foram lavadas em solução de formamida $50 \%$ em $2 x S S C$ por 2 min a $37^{\circ} \mathrm{C}$, um banho de 2xSSC por $1 \min$ a $37^{\circ} \mathrm{C}$ e um banho de PBT (PBS acrescido de $0,1 \%$, tween 20 e $0,15 \%$ de BSA - Sigma) por 5 min à temperatura ambiente.

Procedeu-se à imunodetecção com avidina (no caso de marcação com biotina) ou com anti-digoxigenina (no caso de marcação com digoxigenina) conjugada a FITC (fluorescência verde) ou a rodamina (fluorescência vermelha) em PBT (1:50 em PBT), mantendo-se as lâminas em câmara úmida, por 45 min a $37^{\circ} \mathrm{C}$. Seguiram-se três banhos de PBT de 3 min cada, à temperatura ambiente. Os cromossomos foram corados com iodeto de propídeo $(0,6 \mathrm{ng} / \mu \mathrm{L}$; Sigma $)$ e as lâminas, montadas com DAPI $(0,8 \mu \mathrm{g} / \mathrm{mL}$; Sigma) em Vectashield Mouting Medium (Vector).

As preparações foram observadas em fotomicroscópio de fluorescência Zeiss Axiophot 2. Para documentação, as imagens foram capturadas por uma câmara CCD acoplada ao microscópio e processadas usando-se o programa ISIS (Metasystems). 


\section{III.2.2. ANÁLISES DO DNA}

\section{III.2.2.1 Extração do DNA}

O DNA genômico foi extraído de amostras de aproximadamente $5 \mathrm{~mL}$ sangue periférico, colhidas com o anticoagulante EDTA K3 a 15\% (Vacuntainer). A lise foi feita em solução de sacarose 0,32 M; Tris- $\mathrm{HCl} 10 \mathrm{mM}, \mathrm{pH} 7,4 ; \mathrm{MgCl}_{2} 5 \mathrm{mM}$; TritonX100 a 1\%. Após centrifugação, o precipitado foi ressuspendido em solução tampão ( $\mathrm{NaCl}$ 0,075 M; EDTA 0,02 M), acrescentando-se em seguida uma solução de SDS e solução a $10 \%$ de proteinase K. As amostras foram incubadas por uma noite em estufa a $37^{\circ} \mathrm{C}$. Foi então acrescentado fenol destilado (Merck). As amostras foram centrifugadas e a fase superior, transferida para outro tubo, adicionando-se fenol e clorofórmio:álcool isoamílico (24:1). Após centrifugação, acrescentou-se clorofórmio:álcool isoamílico (24:1) à fase superior. Seguiu-se nova centrifugação e uma solução de $\mathrm{KCl} 2 \mathrm{M}$ e etanol gelado foi acrescentada ao sobrenadante. O DNA precipitado foi removido com auxílio de um capilar de vidro com ponta curva, lavado em etanol 70\%, seco ao ar por alguns minutos e ressuspendido em TE (Tris-HCl 10 mM, EDTA $1 \mathrm{mM}, \mathrm{pH}$ 8,0). A concentração das amostras foi estimada utilizando-se espectrofotômetro, a partir do valor de absorbância a 260 ๆm. A integridade do DNA foi avaliada em gel de $0,8 \%$ de agarose. As amostras de DNA foram mantidas a $-20^{\circ} \mathrm{C}$ até a sua utilização.

\section{III.2.2.2. Análise de loci de microssatélites}

Para a delimitação dos pontos de quebra e determinação da origem parental do rearranjo, utilizamos também a análise de loci de microssatélite, realizada por PCR. Os loci de microssatélites mapeados nas regiões de interesse foram selecionados a partir dos mapas disponíveis nos bancos de dados anteriormente citados.

Os protocolos para a amplificação por PCR seguiram as condições disponíveis no GenBank. Após a eletroforese em gel de agarose $2 \%$ foi realizada coloração com brometo de etídeo.

Para determinação da origem parental da deleção do cromossomo 8, foi genotipado o locus D8S550, parte do kit “ABI PRISM ${ }^{\circledR}$ Linkage Mapping Set v. 2.5MD10" (Applied Biosystems). Os produtos da amplificação foram separados por 
eletroforese em capilar no aparelho MegaBACE ${ }^{\mathrm{TM}} 1000$ (Amersham Biosciences) juntamente com o padrão de peso molecular "MegaBACE ${ }^{\mathrm{TM}}$ ET 550-R Size Standard". A análise foi realizada, utilizando-se o software "Genetic Profiler versão 2.2".

\section{III.2.2.3. Seqüenciamento do DNA}

O seqüenciamento do DNA foi utilizado para identificar mutações em gene candidato a explicar alterações fenotípicas no Paciente 1, o ZNF81. Para isso, visamos as regiões codificadoras desse gene e utilizamos os primers desenhados por Kleefstra et al. (2004). Entretanto, alguns primers usados nesse trabalho para amplificar o exon 6 não funcionaram e, segundo os sítios da internet Primer3 e IDT, eram incompatíveis, pois apresentavam temperaturas de pareamento discrepantes e formavam dímeros que interferiam na PCR. Com isso, desenhamos quatro novos pares de oligonucleotídeos para amplificar esses segmentos (Tabela I). Os produtos de PCR foram purificados utilizando-se o $G F X^{T M}$ PCR DNA and Gel Band Purification Kit (Amersham Biosciences) e em seguida quantificados em gel de agarose $2 \%$, utilizando como padrão o Low DNA Mass Ladder (Invitrogen).

Tabela I. Primers utilizados para a amplificação das regiões codificadoras do gene

ZNF81.

\begin{tabular}{|c|c|c|c|}
\hline $\mathrm{ALVO}$ & ORIENTAÇÃO & OLIGO $\left(5^{\prime} \rightarrow 3^{\prime}\right)$ & PRODUTO \\
\hline \multirow{2}{*}{ EXON 3} & LEFT PRIMER* & GTTCAGCGCTAAGTACCATTGA & \multirow{2}{*}{$858 \mathrm{pb}$} \\
\hline & RIGHT PRIMER* & GAGCTAATTGCAAATTACGAAG & \\
\hline \multirow{2}{*}{ EXON 4} & LEFT PRIMER* & CTCCATCCTCCAGTGCTGATCATG & \multirow{2}{*}{$237 \mathrm{pb}$} \\
\hline & RIGHT PRIMER* & GGGCACAATTTAACCCATAACAGG & \\
\hline \multirow{2}{*}{ EXON 5} & LEFT PRIMER* & CTCAGTTCCCCATGAAATGTGG & \multirow{2}{*}{$286 \mathrm{pb}$} \\
\hline & RIGHT PRIMER* & CCAACCTTTAAGCAATAACAGC & \\
\hline \multirow{2}{*}{ EXON 6 A } & LEFT PRIMER & TCTTGCGGTCTATTGTTTGTG & \multirow{2}{*}{$498 \mathrm{pb}$} \\
\hline & RIGHT PRIMER & CCTGTATGTGTATTTTCGTGGTG & \\
\hline \multirow{2}{*}{ EXON 6 B } & LEFT PRIMER & TTGGGCATGGTCAAGTTTTT & \multirow{2}{*}{$478 \mathrm{pb}$} \\
\hline & RIGHT PRIMER & TGAGTTGTCTGATGCCTGAGT & \\
\hline \multirow{2}{*}{ EXON $6 \mathrm{C}$} & LEFT PRIMER & GCAATGAATGTGGGAAATCA & \multirow{2}{*}{$457 \mathrm{pb}$} \\
\hline & RIGHT PRIMER & TTTGACCTGTTGGTGAAAGC & \\
\hline \multirow{2}{*}{ EXON 6 D } & LEFT PRIMER & AGGCTTTCACCAACAGGTCA & \multirow{2}{*}{$500 \mathrm{pb}$} \\
\hline & RIGHT PRIMER & TCTCATTTTCAAGAAACAGGATT & \\
\hline
\end{tabular}


A reação de seqüenciamento foi realizada segundo o protocolo do fabricante do seqüenciador MegaBACE ${ }^{\mathrm{TM}} 1000$ (Amersham Biosciences), em volume final de reação de $10 \mu \mathrm{L}$, utilizando $30 \mathrm{ng}$ do produto de PCR, 0,5mM de primer e $4 \mu \mathrm{L}$ de DYEnamic ET terminator reagent premix (Amersham Biosciences). Para análise das sequiências,

utilizamos o programa Bioedit Sequence Alignment Editor (http://www.mbio.ncsu.edu/BioEdit/bioedit.html).

\section{III.2.2.4. Southern blotting}

$\mathrm{Na}$ busca por identificar e delimitar os fragmentos de junção dos rearranjos cromossômicos, utilizamos o Southern blotting. A partir da localização dos pontos de quebra nos BAC, conhecendo-se as seqüências das regiões em que estão mapeados, foi possível o desenho de primers que permitiram obter, por PCR, os oligonucleotídeos para serem utilizados como sondas em Southern blotting, para reconhecer os segmentos de junção das quebras, previstos no mapa de restrição.

$\mathrm{O}$ desenho dos primers foi feito a partir de mapas cromossômicos e seqüências genômicas do banco de dados Ensembl e utilizando o programa Primer 3 (http://frodo.wi.mit.edu/cgi-bin/primer3/primer3).

Para a amplificação das sondas, utilizamos cerca de $100 \eta$ g de DNA genômico, em volume final de reação de $25 \mu \mathrm{L}$, na presença de Tris $300 \mathrm{mM}$ (pH 8,5), Hepes 100 mM, MgCl 25 mM, (NH4) $)_{2} \mathrm{SO}_{4} 100$ mM, dNTP $200 \mu \mathrm{M}, 15$ pmoles dos primers foward e reverse e 1 unidade de Taq polimerase. O programa do termociclador consistiu de uma primeira etapa em que o primeiro ciclo tinha temperatura inicial de $94^{\circ} \mathrm{C}$ por $1 \mathrm{~min}$ para a desnaturação, diminuindo até $69^{\circ} \mathrm{C}$ por $30 \mathrm{seg}$ para a hibridação dos primers e aumentando até $72^{\circ} \mathrm{C}$ para a extensão, seguindo-se 13 ciclos em que a temperatura de hibridação diminui $0,5^{\circ} \mathrm{C}$ por ciclo, até atingir a temperatura de $62^{\circ} \mathrm{C}$. A segunda etapa consistiu em 16 ciclos com temperatura de desnaturação de $94^{\circ} \mathrm{C}$, hibridação a $62^{\circ} \mathrm{C}$ e extensão a $72^{\circ} \mathrm{C}$, seguidos de extensão final a $72^{\circ} \mathrm{C}$ por 10 minutos. Os fragmentos amplificados foram visualizados, em gel contendo $2 \%$ de agarose, pela coloração com brometo de etídio, através de trans-iluminação ultravioleta.

Com base nos mapas de restrição dos segmentos de interesse (pDRAW32 1.0 Revision 1.1.88, www.acaclone.com; Webcutter 2.0, http://rna.lundberg.gu.se/cutter2), as amostras de DNA genômico foram submetidas a digestão com as enzimas adequadas, 
segundo protocolo do fabricante. Os fragmentos de DNA resultantes foram separados, em gel de $0,7 \%$ de agarose, por eletroforese e sua transferência para membranas de nylon foi realizada de acordo com o método descrito por Southern (1975).

As sondas foram marcadas com nucleotídio radioativo $\left[\left(\alpha^{32} \mathrm{P}\right)\right.$-dATP $]$ por random priming, utilizando-se o kit de marcação Random Primers DNA Labeling System (Gibco-BRL), conforme as instruções do fabricante. A desnaturação das sondas foi feita por 5 min a $100^{\circ} \mathrm{C}$ e a hibridação por 2 horas a $65^{\circ} \mathrm{C}$. A lavagem foi feita por 20 min à temperatura ambiente em uma solução de $2 x \operatorname{SSC}$ e $0,1 \%$ SDS e 5 min a $65^{\circ} \mathrm{C} \mathrm{em}$ solução 1 XSSC e $0,1 \%$ SDS. Em seguida, as membranas foram secas ao ar e expostas a filmes de raios $\mathrm{X} \operatorname{Kodak}^{\circledR} \mathrm{T}$-MAT, por 1 a 4 dias, a $-70^{\circ} \mathrm{C}$. A revelação dos filmes foi feita automaticamente no aparelho X Kodak RP X-OMAT Processor, no Hospital Universitário da USP. 


\section{RESULTADOS E DISCUSSÃO}

\section{IV.1. DELECÃO DO CROMOSSOMOX}

\section{IV.1.1. MAPEAMENTO DOS PONTOS DE QUEBRA}

No Paciente 1, o exame cromossômico no nível de 550 bandas $\mathrm{G}$ não revelou alterações. O rearranjo cromossômico foi detectado por CGH-array: deleção do BAC RP1-54B20 [cariótipo 46,XY, del(X)(p11)]. No nível de resolução do CGH-array, o segmento deletado ficou restrito a aproximadamente $2 \mathrm{Mb}$. Esse resultado foi validado por FISH realizada em metáfases de sangue periférico da genitora do paciente, o que permitiu a comparação entre os sinais das sondas nos dois cromossomos X. O resultado indicou uma deleção parcial da sonda RP1-54B20 (Figura 3).

Os pontos de quebra foram então delimitados por FISH de segmentos do cromossomo X clonados em BAC (CHORI), mapeados em Xp11.23 (Figura 5).

$\mathrm{O}$ ponto de quebra distal ao centrômero foi localizado no BAC RP1-54B20 (Figura 3), parcialmente deletado, e o proximal, no BAC RP11-38O23 (Figura 4), também parcialmente deletado. Esses BAC estão mapeados em Xp11.23 e se sobrepõem parcialmente em 100 pb (Figuras 5 e 6). 


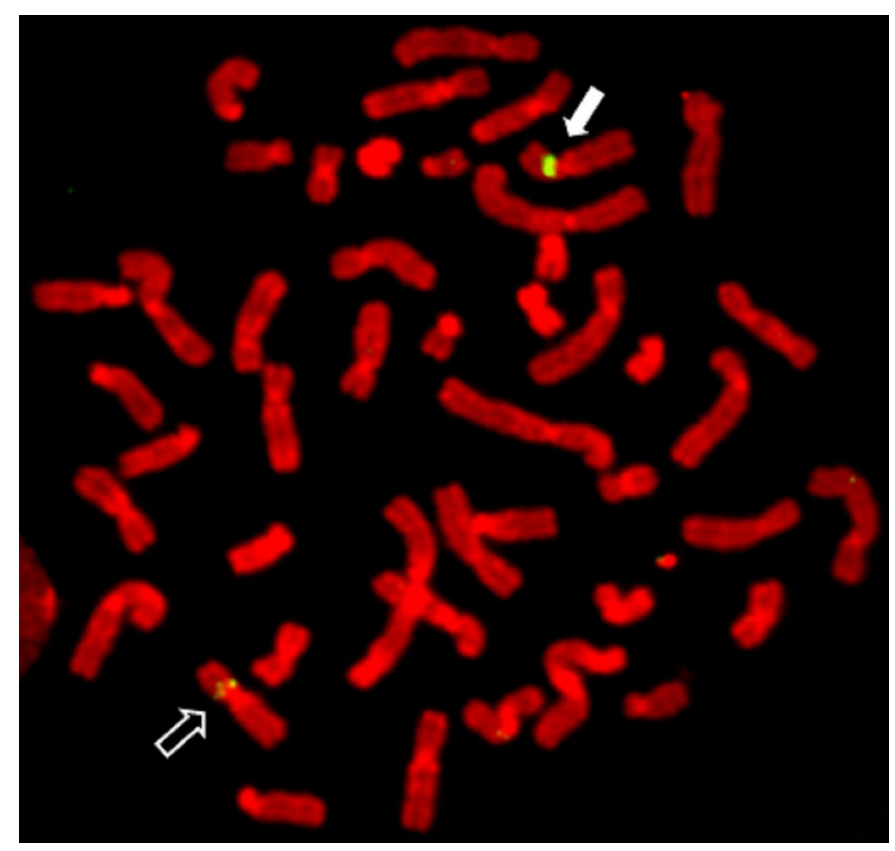

Figura 3. FISH em metáfase da mãe do Paciente 1, mostrando a deleção parcial da sequiência do BAC RP1-54B20 em um dos cromossomos X: a seta preenchida indica o sinal no cromossomo $\mathrm{X}$ normal e a seta vazia indica o cromossomo der(X) com sinal de hibridação relativamente mais fraco.

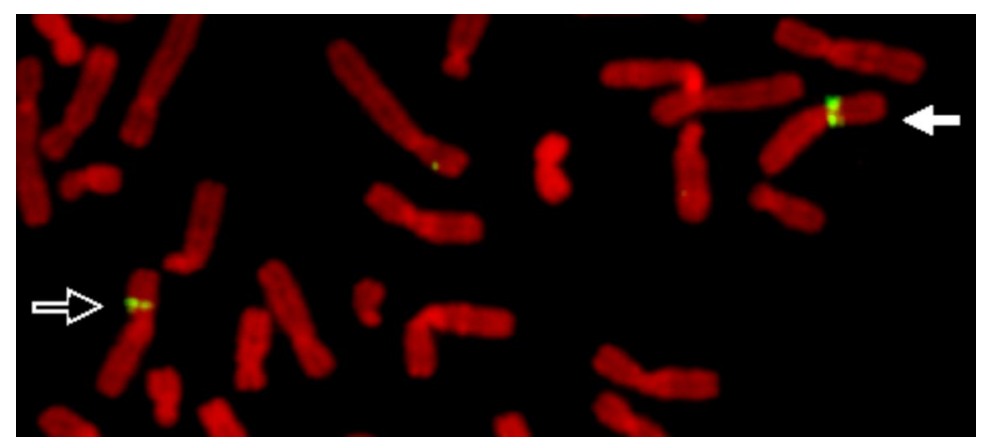

Figura 4. FISH em metáfase da mãe do Paciente 1, mostrando a deleção parcial da seqüência do BAC RP11-38O23 em um dos cromossomos X: a seta preenchida indica o sinal no cromossomo $\mathrm{X}$ normal e a seta vazia indica o cromossomo der(X) com sinal de hibridação relativamente mais fraco. 

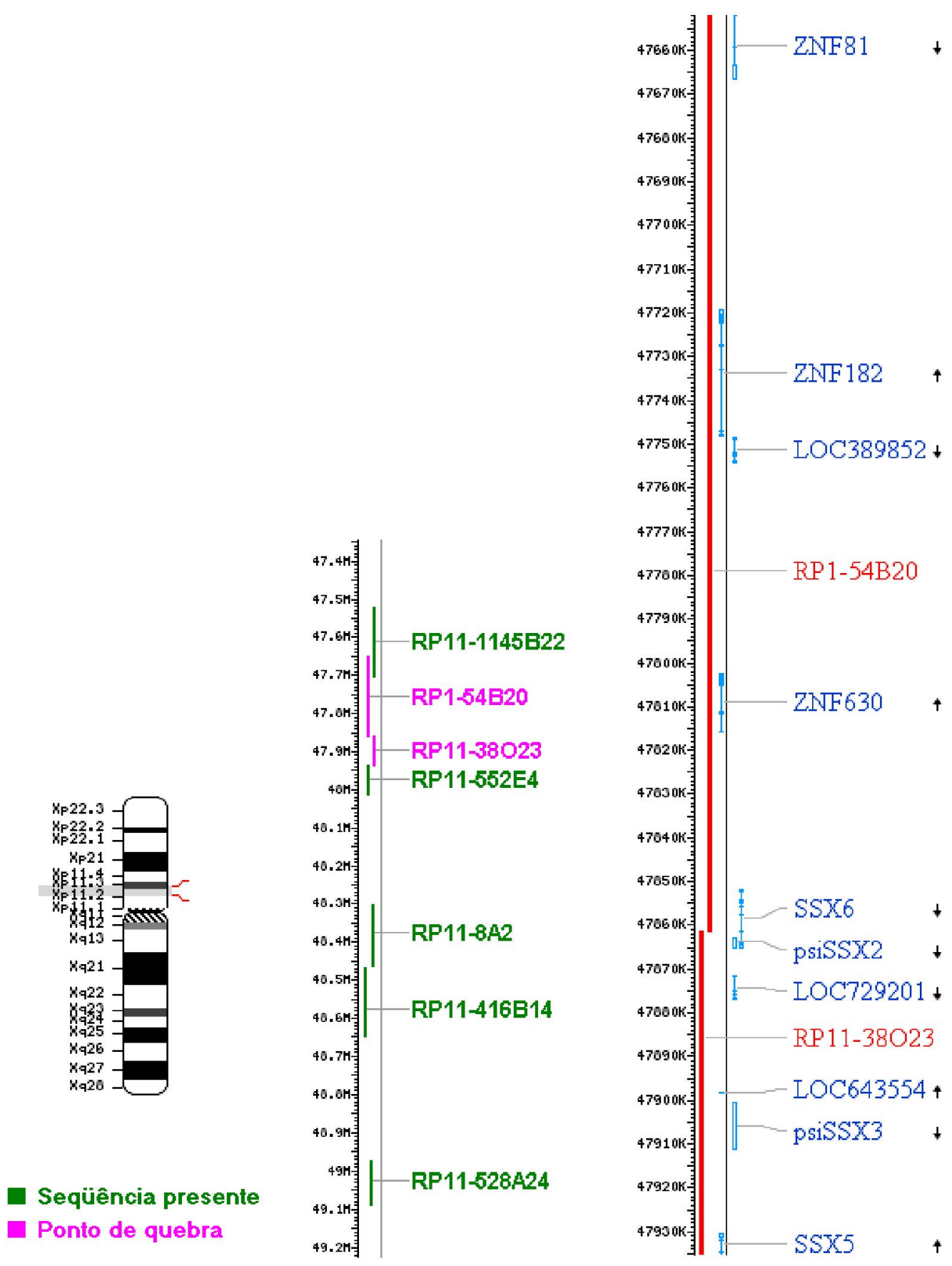

Figura 5. Delimitação do segmento deletado no cromossomo X (NCBI, maio de 2007). À esquerda está um esquema do cromossomo X e a área em cinza representa a região abrangida pelas sondas utilizadas. Ao centro está o mapa da posição relativa dos BAC utilizados para delimitar os pontos de quebra; a régua indica a distância em Mb. À direita está o mapa dos genes e pseudogenes (em azul), contidos na seqüência dos BAC parcialmente deletados (em vermelho); as setas indicam a direção das respectivas seqüências no cromossomo e a régua, a distância em $\mathrm{Kb}$. 


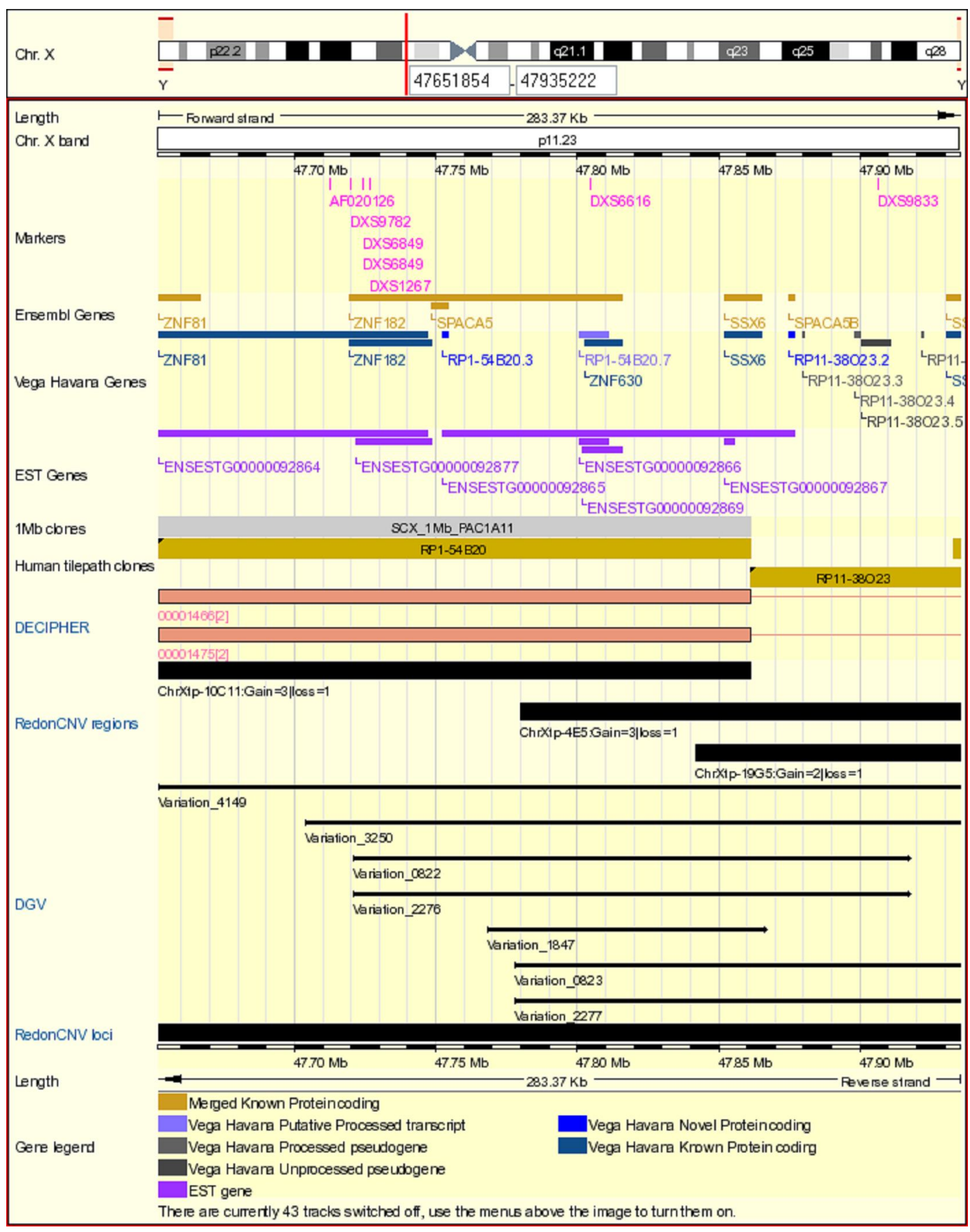

Figura 6. Mapa do trecho do cromossomo X (Ensembl release 44) que corresponde à região clonada nos BAC RP1-54B20 e RP11-38O23 (Human tilepath clones), parcialmente deletados no Paciente 1. Acima está um esquema do cromossomo X, em que a linha vermelha vertical indica o trecho visualizado abaixo. Estão sendo mostrados: o comprimento da seqüência (Length), a banda cromossômica (Chr. X band), o clone do CGH-array (1mb cloneset), os loci de microssatélites (Markers), os genes (Ensembl Genes, EST Genes, Vega Havana Genes), regiões relacionadas a casos clínicos que apresentam microrrearranjos (DECIPHER) e regiões descritas como variações de número de cópias (RedonCNV regions, DGV e RedonCNV loci). 
O refinamento da localização dos pontos de quebra foi feito utilizando-se marcadores do tipo microssatélites. Selecionamos inicialmente os loci DXS1267 (56 pb $\rightarrow$ 47726700-47726755 pb) e DXS6616 (117 pb $\rightarrow$ 47804519-47804635 pb), mapeados no segmento contido no BAC RP1-54B20 (Figura 6 e 9). O resultado mostrou que o Paciente 1 perdeu o locus DXS6616, mas manteve o DXS1267 em seu cromossomo X (Figura 7). Esse resultado permitiu localizar o ponto de quebra distal num segmento de aproximadamente $77,7 \mathrm{~Kb}$.

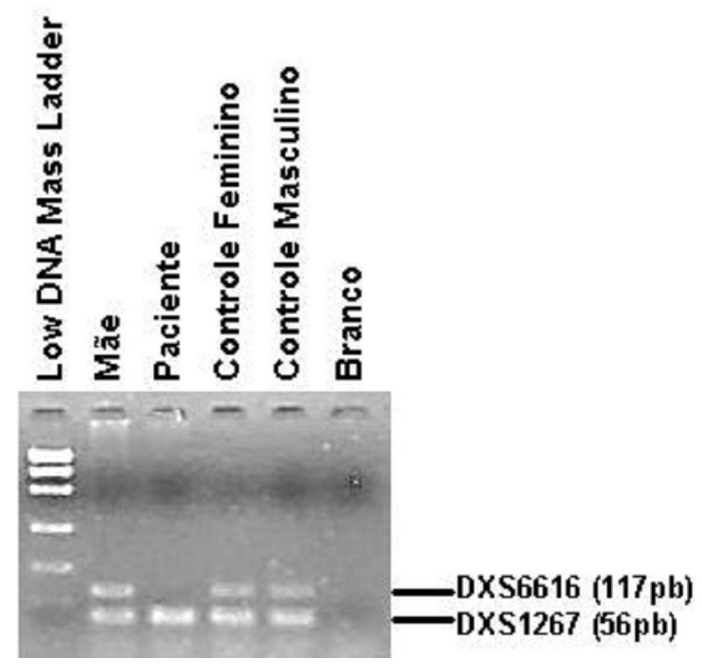

Figura 7. Gel de agarose mostrando os produtos de PCR multiplex dos loci de microssatélites DXS6616 e DXS1267, mapeados no segmento clonado no BAC RP1-54B20 (parcialmente deletado no Paciente 1). A não amplificação do locus DXS6616 indica que se encontra deletado no paciente. A PCR não quantitativa não permite detectar a deleção na mãe do paciente, que possui um cromossomo $\mathrm{X}$ normal, além do deletado [der(X)].

Testamos um outro marcador do tipo microssatélite mapeado na região do ponto de quebra proximal (Figura 6), o DXS9833 (150 pb $\rightarrow$ 47906414-47906565 pb). Verificamos que está presente no Paciente 1 (Figura 8), o que nos permitiu delimitar o ponto de quebra proximal entre esse marcador e a porção distal do BAC RP11-38O23 (47861372pb), em um segmento de no máximo $45 \mathrm{~Kb}$, contendo parte do gene SSX6 e o SPACA5B.

No ponto de quebra distal, mostramos a integridade dos exons 4 e 6 do gene ZNF182 [Vega Havana Genes - OTTHUMG00000021460] (Tabela II e Figura 8). Assim, o ponto de quebra distal foi situado entre a sequiência final da parte traduzida do 
exon 6 de ZNF182 (47735972 pb) e o marcador DXS6616 (47804519 pb), num intervalo de $68547 \mathrm{pb}$, contendo parte dos genes ZNF182 [Ensembl Genes ENSG00000147118] e os genes ZNF630 e SPACA5.

Tabela II. - Seqüência dos primers utilizados para amplificar o exon 4 e a seqüência final da parte traduzida do exon 6 do gene ZNF182 [Vega Havana Genes - OTTHUMG00000021460].

\begin{tabular}{|c|c|c|}
\hline Oligo & Seqüência $\left(\mathbf{5}^{\prime} \rightarrow \mathbf{3}^{\prime}\right)$ & Tamanho do fragmento \\
\cline { 1 - 2 } Exon 4 - Left Primer & GAACCAGGAACCCAATCAGA & \multirow{2}{*}{$219 \mathrm{pb}$} \\
\cline { 1 - 2 } Exon 4 - Right Primer & ACCCACAAAGACCAAGTTGC & \\
\cline { 1 - 2 } Exon 6 - Left Primer & ATGCACTGAGTGTGGCAAAG & \multirow{2}{*}{$160 \mathrm{pb}$} \\
\cline { 1 - 2 } Exon 6 - Right Primer & TTTCTTTCCTGCATGGGTTC & \\
\hline
\end{tabular}

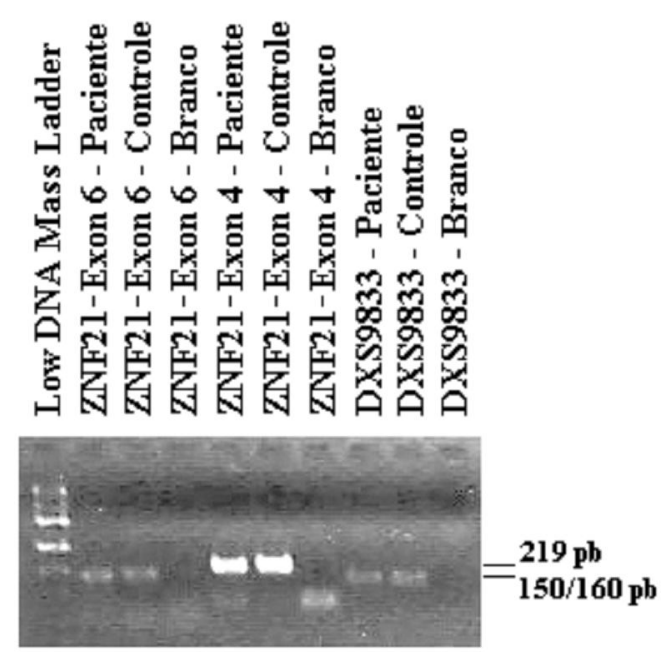

Figura 8. Gel de agarose mostrando os produtos de PCR do exon 4 e da seqüência final da parte traduzida do exon 6 do gene ZNF182 [Vega Havana Genes - OTTHUMG00000021460 mapeado no segmento clonado no BAC RP1-54B20] e do locus de microssatélite DXS9833, mapeado no clone RP11-38O23 (parcialmente deletado no Paciente 1).

O banco de dados NCBI, cuja última atualização do seqüienciamento de referência do genoma humano foi em 31 de agosto de 2006, utiliza a plataforma Build 36.2, assim como o Ensembl. Entretanto, algumas informações contidas em cada um deles nem sempre são equivalentes. O Ensembl em sua versão 44, de abril de 2007, 
apresenta uma interface de trabalho mais prática. Com isso, utilizamos o banco de dados Ensembl como referência para as análises a seguir.

A análise in silico da região dos pontos de quebra mostrou a presença de dois genes semelhantes, ambos codificadores de proteína, SPACA5 e SPACA5B (anteriormente denominados de PNPK6288 ou de NP_995328.1 e considerados idênticos), um na seqüência do clone RP1-54B20 e outro na do RP11-38O23 (Figura 6). Utilizando o aplicativo BLAST (NCBI) entre o gene SPACA5 [ENSG00000171489], de 5393 pb (47748678-47754070 pb), e o gene SPACA5B [ENSG00000171478], de 1957 pb (47874983-47876939 pb), verificamos a existência de 99\% de identidade de seqüência, compreendendo todo o gene $S P A C A 5 B$ e a porção final do gene $S P A C A 5$, a partir de 3437 pb de seu início. Além disso, utilizando o BLAST para a verificação de similaridades entre os BAC RP1-54B20 e RP11-38O23, observamos que há uma região de 16453 pb (47748657-47765110pb) em RP11-54B20 (Bloco A) em que há identidade com um bloco de 15847 pb (47871526-47887373 pb) em RP11-38O23 (Bloco B). Os únicos genes presentes nesses blocos são SPACA5, no bloco $\mathrm{A}$, e $S P A C A 5 B$, no bloco B. O BLAST entre essas duas regiões de aproximadamente $16 \mathrm{~Kb}$ dos dois clones mostra seqüências ininterruptas de 282 a 5948 pb com mais de $95 \%$ de similaridade. A distância entre os genes SPACA5 e SPACA5B é de 120913 pb e a distância entre os blocos de identidade A e B nos dois BAC é de 106416 pb (Figura 9). 


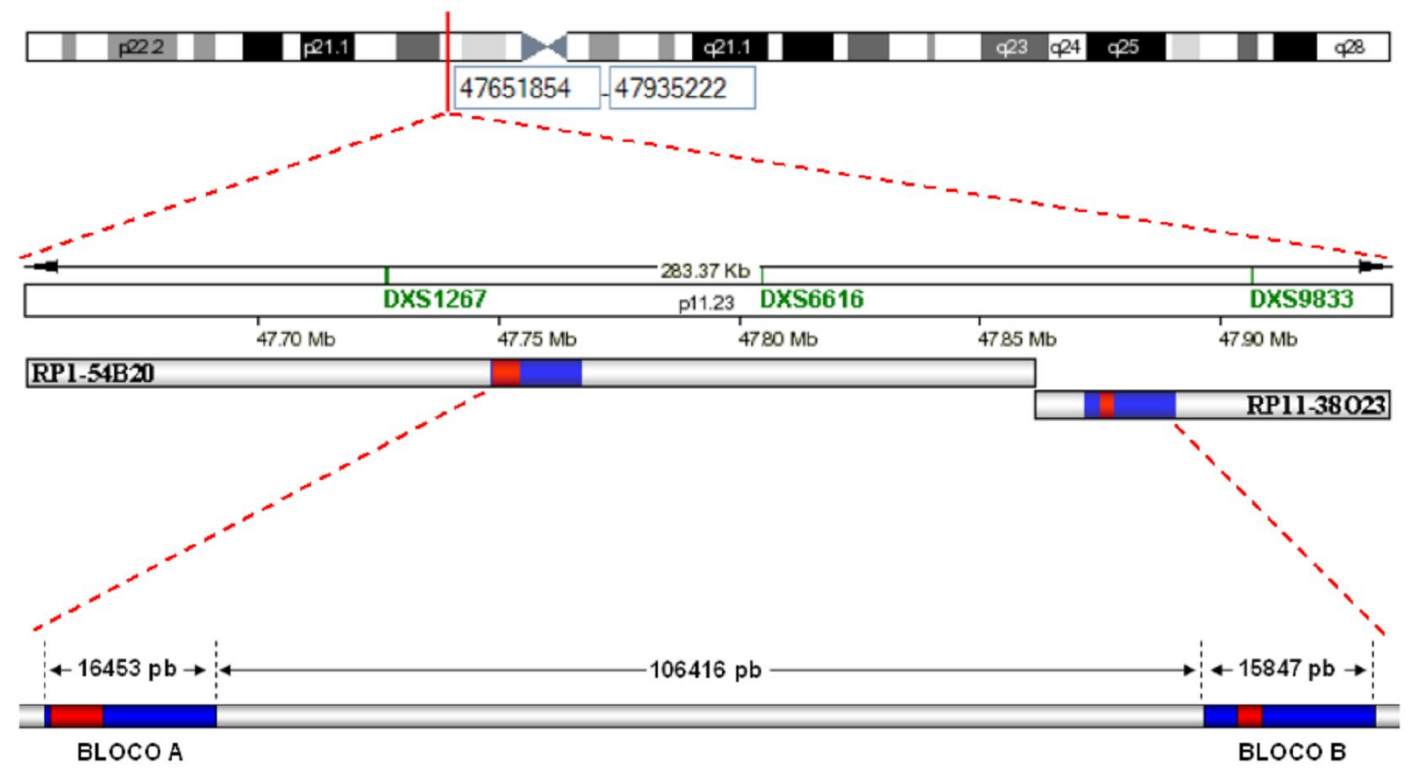

Figura 9. Esquema do segmento do cromossomo $X$ na região do rearranjo (Ensembl release 44). Os blocos vermelhos representam os genes SPACA5 (clone RP1-54B20) e SPACA5B (clone RP11-38023) e os azuis representam as outras regiões de identidade entre os BAC parcialmente deletados no Paciente 1.

Em várias síndromes causadas por deleção/duplicação cromossômica, os segmentos genômicos afetados estão flanqueados por elementos repetidos de elevada homologia, estruturas que podem atuar como substrato de recombinação homóloga não alélica (Shaw e Lupski, 2004). Levando em consideração a identidade de seqüência entre esses segmentos em que localizamos os pontos de quebra, nossa hipótese foi que uma recombinação homóloga não alélica entre eles tenha originado a deleção.

Elaboramos como estratégia para a detecção dos blocos de $\sim 16 \mathrm{~Kb}$ de alta identidade um experimento de PCR que indicasse a presença ou não das extremidades dos blocos de repetição (Tabela III e Figura 10A). Para amplificar o início do bloco A, desenhamos um left primer cuja extremidade 5' está a 103 pb do início do bloco e um right primer com extremidade 3' a 178 pb após o início do bloco, o que gerava um fragmento de $281 \mathrm{pb}$. Para amplificar o início do bloco B, elaboramos um left primer que precede em 297 pb o início bloco e o right primer utilizado foi o mesmo da reação de PCR anterior, o que gerava um fragmento de $475 \mathrm{pb}$. Para amplificar o fim do bloco A, elaboramos um left primer cuja extremidade 5' está a 26 pb do fim do bloco e um right primer com extremidade 3' a 373 pb após o fim do bloco, o que gerava um 
fragmento de $399 \mathrm{pb}$. Para amplificar o fim do bloco B, utilizamos o mesmo left primer da reação anterior e um right primer com extremidade 3' a 184 pb após o fim do bloco, o que gerava um fragmento de $210 \mathrm{pb}$.

No paciente, não foram amplificadas as seqüências do início do bloco B e do fim do bloco A (Figura 10). Esses resultados são compatíveis com a participação dos blocos de alta similaridade de seqüência, que incluem os genes SPACA5 e SPACA5B, na formação do rearranjo, pela recombinação homóloga não alélica.

Tabela III. Primers utilizados para a amplificação das extremidades dos blocos de alta identidade de seqüência $\left(5^{\prime} \rightarrow 3^{\prime}\right)$ e as respectivas posições em pb no cromossomo $\mathrm{X}$ das extremidades 5 '.

\begin{tabular}{|c|c|c|c|}
\hline $\begin{array}{c}\text { INÍCIO DO BLOCO } \\
\text { DISTAL }\end{array}$ & LEFT PRIMER & TTATGCAGAGGCAGGCACT & 47748554 \\
\cline { 2 - 4 } & RIGHT PRIMER & ACCCACCGTCCTTCAAAC & 47748834 \\
\hline $\begin{array}{c}\text { INÍCIO DO BLOCO } \\
\text { PROXIMAL }\end{array}$ & LEFT PRIMER & GGGCGATCTTTAAACACATCA & 47871229 \\
\cline { 2 - 4 } & RIGHT PRIMER & ACCCACCGTCCTTCAAAC & 47871703 \\
\hline \multirow{2}{*}{ FIM DO BLOCO DISTAL } & LEFT PRIMER & CCTTTTTCCGACCTTTATCC & 47765007 \\
\cline { 2 - 4 } & RIGHT PRIMER & TGCCAGCCAAATACGTACAA & 47765405 \\
\hline $\begin{array}{c}\text { FIM DO BLOCO } \\
\text { PROXIMAL }\end{array}$ & LEFT PRIMER & CCTTTTTCCGACCTTTATCC & 47887274 \\
\cline { 2 - 4 } & RIGHT PRIMER & CCATGGTTTGAATGTCCTCA & 47887483 \\
\hline
\end{tabular}




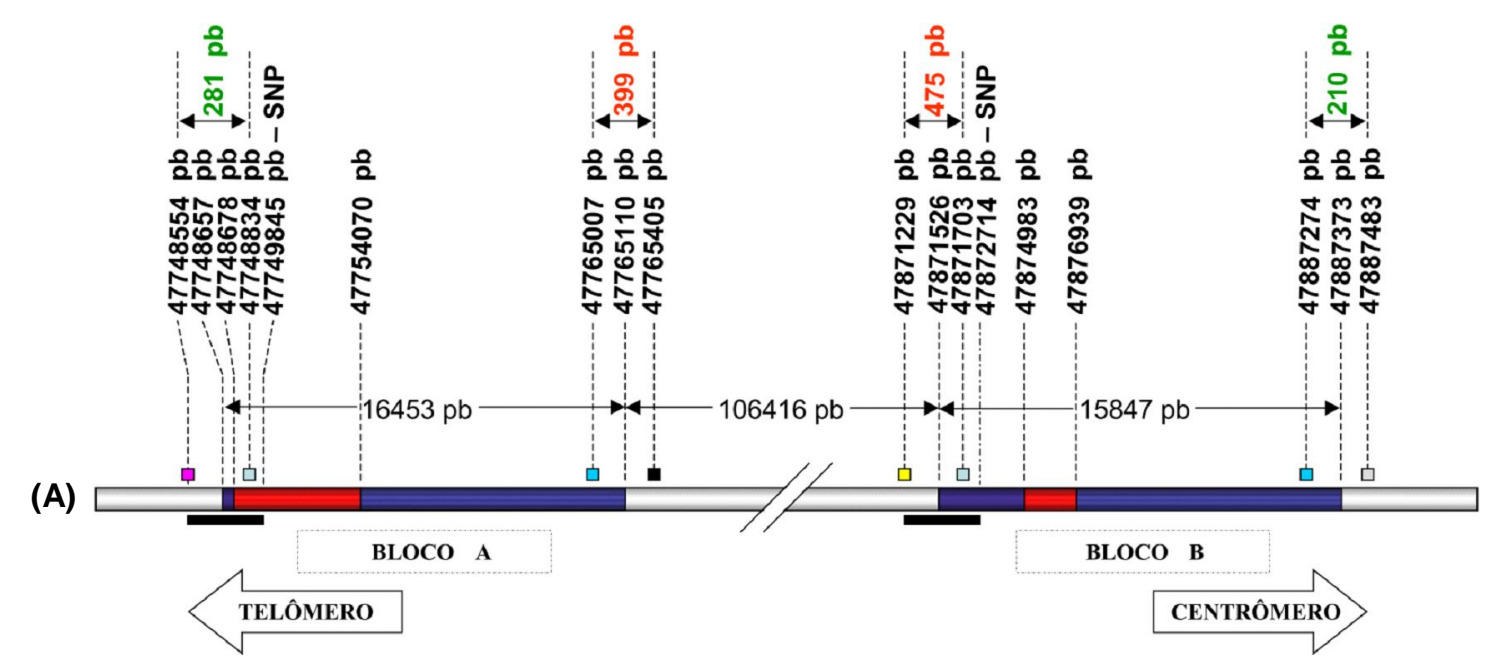

(B)

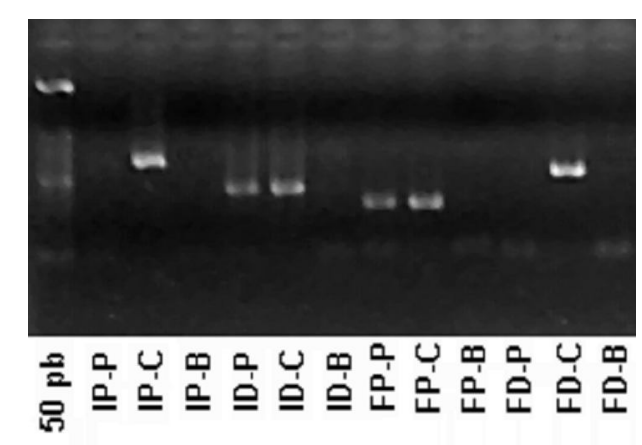

Figura 10. (A) Esquema da região dos blocos de repetição A e B que contêm os genes SPACA5 e $S P A C A 5 B$ (barras vermelhas) e as outras regiões de identidade (barras azuis) entre os BAC parcialmente deletados no Paciente 1. Os quadrados coloridos acima das barras representam os primers utilizados para a amplificação por PCR das extremidades dos blocos de repetição (os quadrados de mesma cor simbolizam o mesmo primer). $\mathrm{O}$ tamanho em $\mathrm{pb}$ dos produtos de PCR está representado em verde (sequiência amplificada tanto no paciente quanto em individuo controle) e vermelho (seqüência amplificada apenas em indivíduo controle). O SNP a 1189 pb

do início de cada bloco e que os distingue está indicado. As barras negras representam os segmentos delimitados para os pontos de quebra. A posição de cada estrutura representada, inclusive a posição do SNP a 1189 pb do início dos dois blocos e que os distingue, é dada em pares de bases do cromossomo X (Ensembl release 44). (B) Amplificação das extremidades dos blocos A e B: gel de agarose, corado com brometo de etídio, mostrando os produtos de PCR e o marcador de peso molecular de $50 \mathrm{pb}$; as canaletas indicadas pelas letras P, C e B correspondem a Paciente, Controle clinicamente normal e Branco, respectivamente. No paciente, não foram amplificadas as sequiências do início do bloco B (IP-P) e do fim do bloco A (FD-P). 
Simultaneamente, estabelecemos colaboração com o grupo de pesquisa do Dr. Hans Bokhoven e da Dra. Dorien Lugtenberg, do Nijmegen Medical Centre, da Holanda, que também possui pacientes com o mesmo padrão de deleção, para a análise de polimorfismos de um único nucleotídeo (SNP) ao longo dos blocos A e B. O grupo holandês estabeleceu as variantes exclusivas de cada bloco e, a partir daí, identificou aquelas que cada paciente possuía. Ficou demonstrado que o nosso paciente apresenta todos os polimorfismos estudados do bloco B e nenhum do blocoA.

O SNP mais distal estudado estava a 1189 pb do início dos blocos (nas posições 47749845 e 47872714 pb do cromossomo X - Figura 10A), no intron 1-2 (47748760$47752058 \mathrm{pb}$ ) de um dos transcritos [ENST00000304355] do gene SPACA5, estando apenas a variante do bloco B presente no paciente. O ponto de quebra proximal pôde ser localizado telomérico a esse SNP, entre ele e o left primer, que utilizamos para amplificar o início do bloco B, um segmento de 1486 pb. Quanto ao ponto de quebra distal, estando o SNP ausente, ele pôde ser localizado entre o left primer utilizado para amplificar o início do bloco A e o SNP, um segmento de 1292 pb. Os segmentos delimitados para a quebra contêm 1189 pb dos blocos de repetição, com 99\% de identidade de seqüência, entre parte do gene SPACA5 no bloco A e a seqüência do bloco B que precede o gene $S P A C A 5 B$. Portanto, a recombinação homóloga entre esses segmentos pode ter originado a deleção. Dessa forma, o fragmento deletado teria aproximadamente $123 \mathrm{~Kb}$ de extensão.

\section{IV.1.2. A DELEÇÃO E O QUADRO CLÍNICO}

A relação mais simples que pode ser estabelecida entre uma deleção do cromossomo $\mathrm{X}$ e o quadro clínico no sexo masculino é que a ausência de genes na região deletada seja a causa do fenótipo. Há quatro genes mapeados na região delimitada para a deleção (figura 6): SSX6, SPACA5, ZNF182 e ZNF630.

\section{SSX6 [ENSG00000171483 ou OTTHUMG00000021464]}

O gene SSX6 (Sarcoma, sinovial, X breakpoint 6) faz parte da família de genes $S S X$, mapeados em Xp11. Como todos os genes SSX, contém 10 exons, dos quais oito (2 a 9) são transcritos. A proteína hipotética tem 188 aminoácidos e contém um domínio 
KRAB (KRuppel-Associated Box), típico da família (Gure et al., 2002). O mRNA foi detectado em linhagem celular de melanoma humano, mas em nenhum tecido normal examinado. Este gene não aparece, portanto, como um candidato para a deficiência mental.

\section{SPACA5 [LOC389852 - ENSG00000171489] e SPACA5B [LOC729201 - ENSG00000171478] (também denominados de NP_995328.1 ou PNPK6288)}

Chen et al. (2006) identificaram cinco novas famílias de genes com expressão específica em testículos e mais de $98 \%$ de similaridade de seqüência entre os membros das famílias, numa busca de aglomerados de transcritos de loci do cromossomo X, seguida da análise in silico do perfil de expressão dos genes. Os autores identificaram duas repetições diretas do gene LOC389852 (SPACA5), em Xp11.23. O mRNA foi encontrado especialmente em testículo, mas também detectado em diversos tecidos somáticos, como cérebro, cólon, rim, pâncreas e próstata. A proteína de 159 aminoácidos tem atividade de lisozima, participa do catabolismo da parede celular e é encontrada no meio extracelular (NCBI - revisado em 30 de outubro de 2006).

O banco de dados Ensembl (release 44), entretanto, considera a existência de dois trancritos do gene SPACA5 (LOC389852): um transcrito a partir de 5 exons, com extensão de 648 pb e traduzido numa proteína de 159 aminoácidos [ENST00000304355]; o outro transcrito a partir de 4 exons, com 571 pb e também traduzido numa proteína de 159 resíduos [ENST00000376940]. As duas proteínas têm identidade de $100 \%$ (BLAST, NCBI).

O gene $S P A C A 5 B$, que não está deletado, é transcrito unicamente a partir de 4 exons, tem $595 \mathrm{pb}$ e é traduzido em uma proteína de 159 aminoácidos [ENST00000304270]. O pareamento (BLAST, NCBI) dessa proteína com aquela produzida pelo SPACA5 mostrou $99 \%$ de identidade, diferindo em um único aminoácido (assinalado abaixo em negrito): 


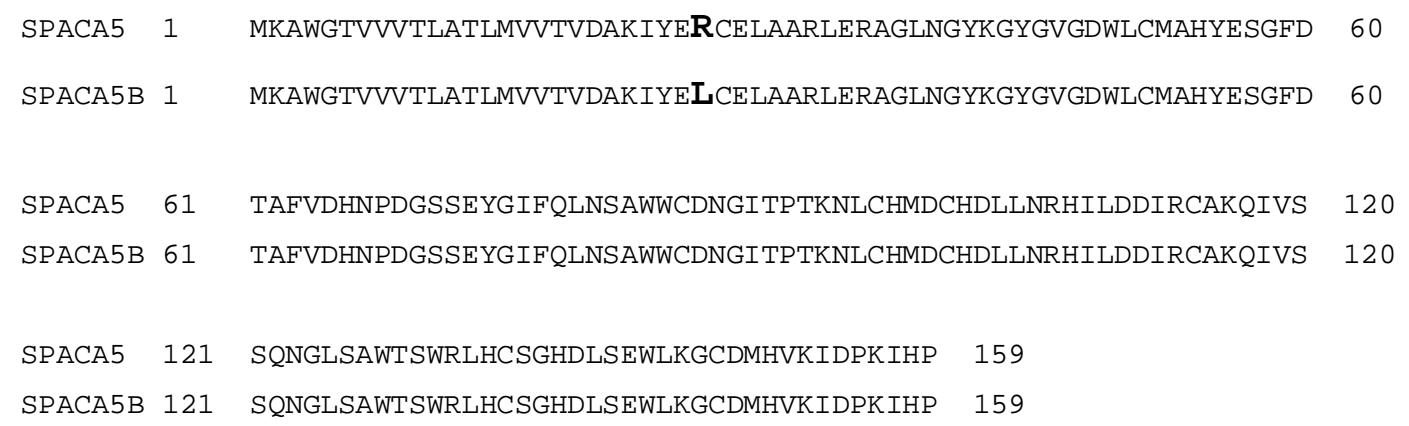

Conforme nossos resultados de mapeamento dos pontos de quebra (Figura 10), é provável que tenha ocorrido recombinação homóloga não alélica entre o gene SPACA5 e o segmento de homologia que precede o gene $S P A C A 5 B$, resultando na deleção. Assim o gene SPACA5 estaria alterado pela recombinação. Um efeito clínico de um novo produto gênico poderia ocorrer, mas desconhecendo-se a função desse gene e havendo a possibilidade de complementação funcional pelo produto do gene $S P A C A 5 B$ não nos é possível ir além de considerar sua participação no fenótipo como uma possibilidade.

\section{ZNF630 (XP_033853.2) [OTTHUMG00000021463] e ZNF182 [ENSG00000147118 ou OTTHUMG00000021460]}

A família protéica do tipo zinc finger (ZNF) [ENSF00000000001] está representada por 452 genes na espécie humana (Ensembl release 44). As proteínas variam na estrutura, mas possuem um domínio que requer um ou mais íons de zinco para estabilizar sua estrutura (UniProt). Ligam-se a ácidos nucléicos e desempenham funções diversas, sendo a principal a de regular a transcrição (Bellefroid et al., 1991). Pelo menos três genes que codificam proteínas zinc-finger, ZNF41 (MIM 314995), ZNF81 (Kleefstra et al., 2004) e ZNF674 (Lugtenberg et al., 2006) foram encontrados mutados em pacientes com retardo mental ligado ao $\mathrm{X}$.

Os genes ZNF630 e ZNF182 codificam proteínas zinc-finger expressas principalmente no cérebro (GeneCard database).

O banco de dados Ensembl (release 44), entretanto, mostra quatro transcritos do gene ZNF182 (Figura 11). O primeiro, NP_001007089.1 [ENST00000376943], com $3486 \mathrm{pb}$, é produto de 6 exons e gera uma proteína de 620 aminoácidos. O segundo, ZN630_HUMAN [ENST00000276054], é transcrito de 5 exons, tem 2561 pb e é traduzido numa proteína de 533 aminoácidos. É idêntico ao transcrito do gene ZNF630, 
o ZNF630-001 [OTTHUMT00000056456]. O terceiro transcrito, ZN182_HUMAN [ENST00000305127], também descrito pelos bancos de dados UniProt e GeneCard database, é originado de 4 exons, tem 3227 pb e codifica para uma proteína de 639 resíduos. O quarto, ENST00000359880, proveniente de 3 exons, com 2082 pb e que produz uma proteína de 694 aminoácidos, é resultante da mais longa transcrição do gene ZNF182, pois inclui o gene SPACA5 em um de seus introns e tem o primeiro exon do gene ZNF630 como o seu último exon.

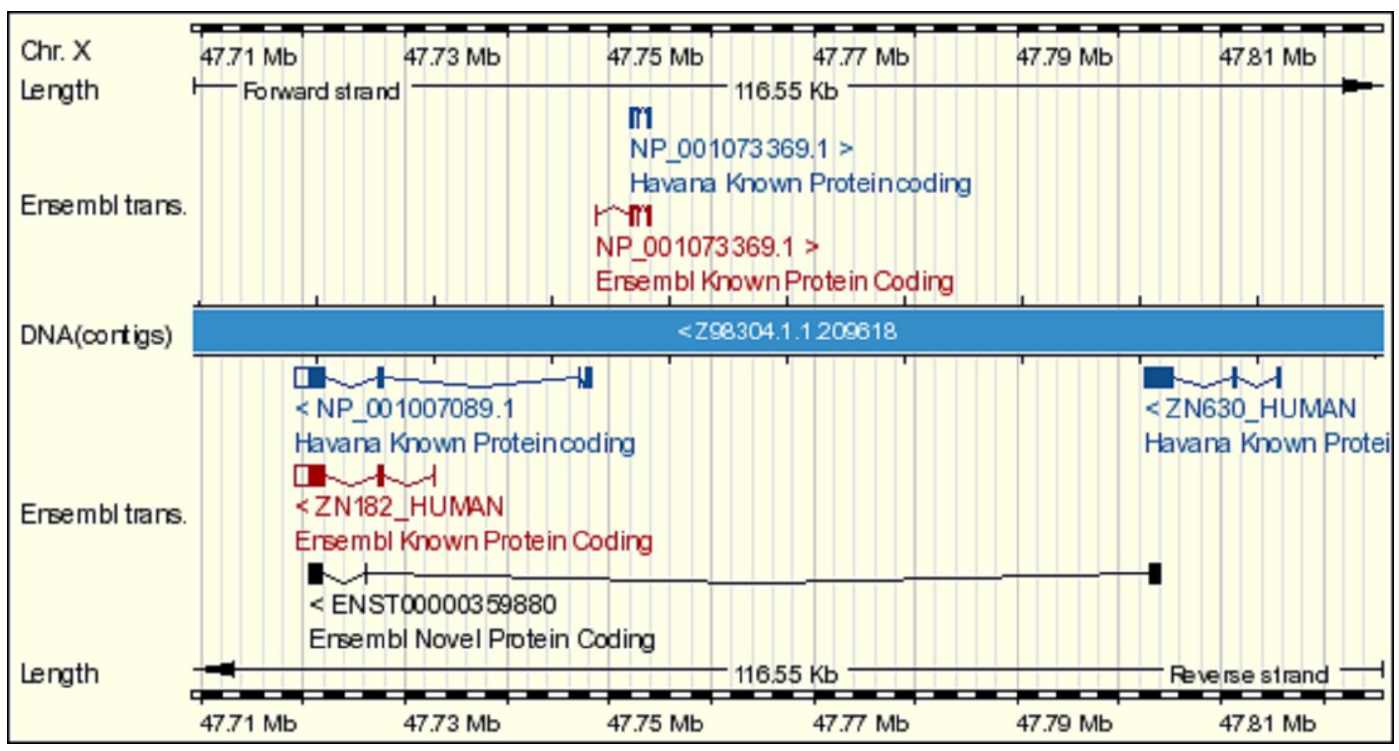

Figura 11. Mapa da região do cromossomo $X$ que mostra os transcritos dos genes ZNF182

(NP_001007089.1; ZN182_HUMAN; ENST00000359880; ZN630_HUMAN), SPACA5 (NP_001073369.1 - Havana e Ensembl Protein Coding) e ZNF630 (ZNF630-001 - idêntico ao ZN630_HUMAN) (Ensembl release 44).

Estando ausentes o gene ZNF630 e parte do gene ZNF182 (afetando o transcrito ENST00000359880), ambos são candidatos, contribuindo para a deficiência mental.

Entretanto, o segmento delimitado pelos pontos de quebra está contido numa região do cromossomo $\mathrm{X}$ em que ocorrem variações de número de cópias do DNA (Figura 6). Microduplicações polimórficas foram descritas em Xp11.23 (The Centre for Applied Genomics), assim como microdeleções (Redon et al., 2006 - Figura 6). A microdeleção que descrevemos pode, assim, estar casualmente associada com o fenótipo na família que estudamos. Essa pode também ser a explicação para uma microdeleção 
de $50 \mathrm{~kb}$, mais proximal ao centrômero em relação a que aqui descrevemos, que foi relatada por Froyen et al. (2007), em associação com deficiência mental. Ou para a microduplicação mais extensa, incluindo esse segmento deletado, também associada a deficiência mental, que foi descrita anteriormente por Bonnet et al.(2006).

Uma vez que a microdeleção que estudamos pode ser uma variante estrutural genômica sem efeito fenotípico, levamos em conta a possibilidade de que um gene ligado à deleção estivesse mutado, causando a deficiência mental na família. O gene ZNF81 [ENSG00000197779] (47581245-47666554 pb), localizado upstream em relação à região deletada que delimitamos, 32 Kb de distância (Figura 6), surgiu como o principal candidato, sendo o mais próximo à deleção e já tendo sido relacionado com deficiência mental. Kleefstra et al. (2004) mostraram que o ponto de quebra do cromossomo $\mathrm{X}$ de uma translocação, $\mathrm{t}(\mathrm{X} ; 9)(\mathrm{p} 11.23 ; \mathrm{q} 34.3)$, em uma mulher com retardo mental grave, rompeu o gene ZNF81 e o fundiu com um elemento Alu no cromossomo 9. A investigação de mutações nesse gene em mais de 300 famílias com indivíduos com retardo mental ligado a Xp11.2 revelou uma mutação 536G-A, que corresponde a uma substituição S179N, segregando com o retardo mental na família MXR45 descrita por Hamel et al. (1999). Essa mutação não foi detectada em 451 cromossomos X de indivíduos controle. O ponto de quebra no cromossomo 9 rompeu o gene Eu-HMTase1, o que pode ter contribuído para algumas das características dismórficas da paciente portadora da translocação. Assim, Kleefstra et al. (2004) sugeriram que tal mutação no gene ZNF81 pode ser causa de retardo mental não específico ligado ao X.

Os primers e condições de amplificação para a análise da região codificadora do gene ZNF81 no Paciente 1 estão descritos no item Pacientes e Métodos (Pág. 18). O seqüenciamento não revelou qualquer alteração, nem mesmo variantes (Ensembl release 42).

Existe, é claro, a possibilidade de que uma mutação em outro gene qualquer do cromossomo X seja a causa do fenótipo, não tendo relação com a microdeleção.

Entretanto a relação entre microdeleções e microduplicações com fenótipos clínicos pode ser mais complexa. A literatura começa a registrar casos sugestivos de que certas alterações genômicas possam na verdade contribuir para uma susceptibilidade à doença e não serem determinísticas do fenótipo per se. É o caso da deleção de $200 \mathrm{~Kb}$, em 1q21.1, detectada por Klopocki et al. (2007) em todos os 30 pacientes investigados com síndrome de TAR (trombocitopenia hipomegacariocítica e aplasia radial). A deleção não foi encontrada em 700 indivíduos controle, reforçando a interpretação da 
relação causal com a doença. Entretanto, foi herdada em $75 \%$ dos casos, em sua maioria de genitores normais. Os dados levaram os autores a postularem que a síndrome está de fato relacionada à deleção, mas o fenótipo só se manifestaria na presença de alguma alteração adicional no genoma. Ullmann et al. (2007) identificaram uma duplicação de 1,5 Mb por CGH-array, flanqueada por LCR, em 16p13, em quatro homens autistas de três famílias não relacionadas, em alguns de seus parentes normais e afetados em graus variáveis. A deleção do mesmo intervalo foi detectada em outros três pacientes com deficiência mental e outras anomalias clínicas. Variações de número de cópias não haviam sido descritas para essa região e nem foram encontradas em mais de 600 indivíduos analisados. Com isso, os autores sugerem que essas alterações predisporiam ao autismo e à deficiência mental.

Assim, o estudo dos demais afetados em outros ramos da família, quanto ao quadro clínico e a presença da microdeleção, é imprescindível para avaliar todas essas possibilidades. 


\section{IV.2. DELECÃO DO CROMOSSOMO 8}

\section{IV.2.1. MAPEAMENTO DOS PONTOS DE QUEBRA}

A Figura 12 mostra o cromossomo 8 com deleção parcial do braço curto, após bandamento GTG. O ponto de quebra foi mapeado em 8p23. Essa deleção foi detectada na Paciente 2 e em seu pai.

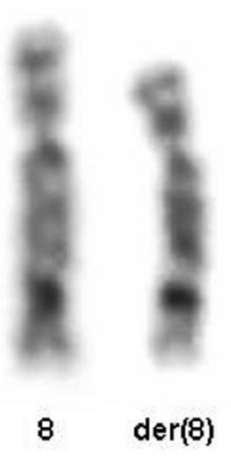

Figura 12. Par de cromossomos 8 da Paciente 2, após bandamento GTG. Observa-se a deleção parcial do braço curto, com o ponto de quebra mapeado em $8 \mathrm{p} 23$.

A hibridação da sonda subtelomérica de $8 \mathrm{p}$ (Vysis) mostrou que a região estava presente no cromossomo der(8) (Figura 13) e que, portanto, a deleção era intersticial.

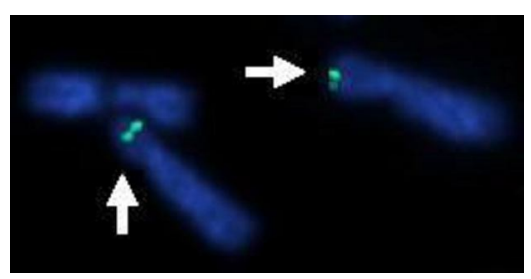

Figura 13. As setas indicam a sonda subtelomérica de $8 \mathrm{p}$ (Vysis), que hibrida com os cromossomos 8 normal e deletado.

Os pontos de quebra foram delimitados por FISH de segmentos do cromossomo 8 clonados em BAC (CHORI) (Figura 16). O ponto de quebra distal pôde ser localizado 
na seqüência do BAC RP11-556O5 (8p23.1), que está parcialmente deletado no der(8) (Figura 14).

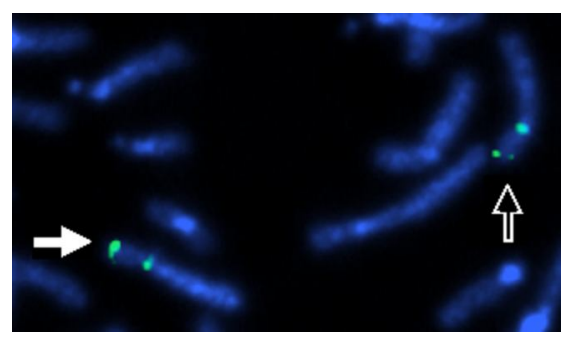

Figura 14. Ponto de quebra distal: a seta preenchida indica o sinal do BAC RP11-556O5 no cromossomo 8 normal e a seta vazia indica o cromossomo der(8) com sinal de hibridação relativamente mais fraco presente no $\operatorname{der}(8)$ (a sonda alfóide específica marca os centrômeros).

O ponto de quebra proximal foi delimitado pelos BAC RP11-589N15 (11627380-11803128 pb - deletado) e RP11-481A20 (11778967-11929473 pb - não deletado) (Figura 15). Esses BAC localizam-se em 8p23.1 e se sobrepõem parcialmente em $24161 \mathrm{pb}$.
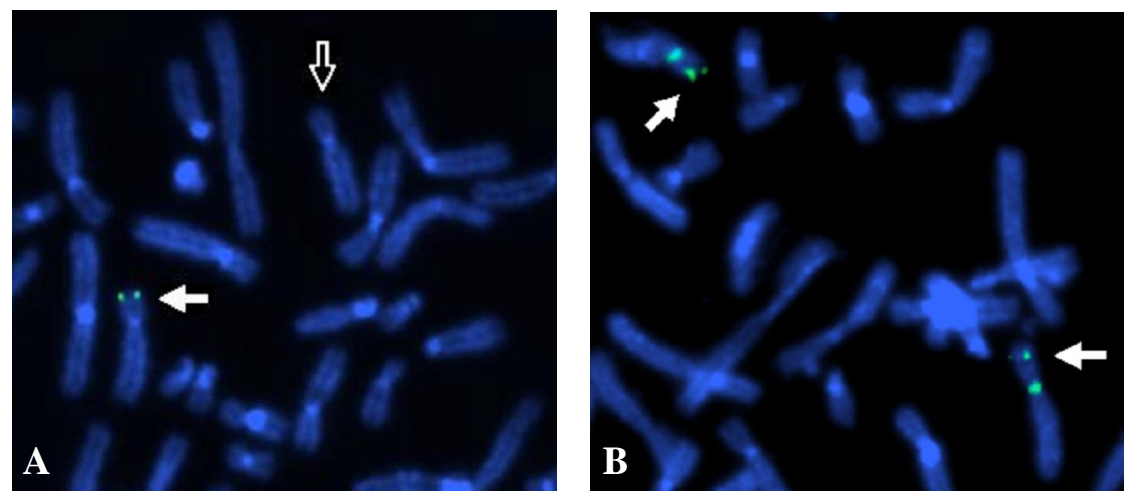

Figura 15. Limites do ponto de quebra proximal: (A) seta preenchida indica o sinal do BAC RP11-589N15 no cromossomo 8 normal e a seta vazia indica o cromossomo der(8) sem sinal de hibridação; (B) o BAC RP11-481A20 hibridou nos dois cromossomos do par 8; a sonda alfóide específica marca os centrômeros. A porção distal desse BAC sobrepõe-se com a porção proximal do BAC RP11-589N15. 
Estando os BAC do ponto de quebra proximal superpostos, um produzindo sinal e o outro não, o ponto de quebra deve estar localizado na seqüência de um deles, não produzindo alteração detectável pela hibridação dos BAC: existe a possibilidade da presença de um pequeno segmento do BAC deletado e de pequena deleção do BAC presente, que não alterem os sinais de hibridação.

A partir da delimitação por FISH dos pontos de quebra, distantes cerca de 3,9 $\mathrm{Mb}$, em 8p23.1, realizamos análises in silico dos segmentos envolvidos. Utilizamos o aplicativo BLAST, disponibilizado pelo banco de dados NCBI, para investigar segmentos de homologia entre as seqüências dos BAC que contêm os pontos de quebra. No alinhamento entre os BAC RP11-556O5 (ponto de quebra distal) e RP11-481A20 (ponto de quebra proximal), verificamos a existência de pelo menos duas grandes regiões de homologia entre as seqüências: uma apresenta 4506 pb com $90 \%$ de identidade e a outra 2160 pb com $89 \%$ de identidade. Essas duas regiões (Figura 17) são constituídas por sequiências de retrovírus endógenos humanos (HERV) do grupo E: HERVE.

Analisando os clones de forma mais aprofundada (Figura 18), observamos que, na seqüência do BAC RP11-556O5, existe um grande HERVE, de 7826 pb (80671938075019pb), que, para distingui-lo dos demais, denominamos de HERVE(A). No BAC RP11-481 A20 existem dois blocos de HERVE, um de 2158 pb e outro de 4508 pb. Entretanto, esses dois blocos apresentam dois HERVE cada. O primeiro possui um HERVE(B) de 1094bp (11802035-11803128pb) e um HERVE(C) de 1171pb (11807037-11808207pb). O segundo apresenta um HERVE(D) de 668bp (1182795211828619pb) e um HERVE(E) de 2159bp (11828629-11830787pb). Além de HERVE, o BAC RP11-481A20 também contém seqüências de receptores olfativos (OR) e de defensinas (DEF), que, assim como os HERV, podem favorecer a recombinação homóloga não alélica. Entretanto, não há OR e nem DEF na sequiência do BAC RP1155605 (Figura 25). 


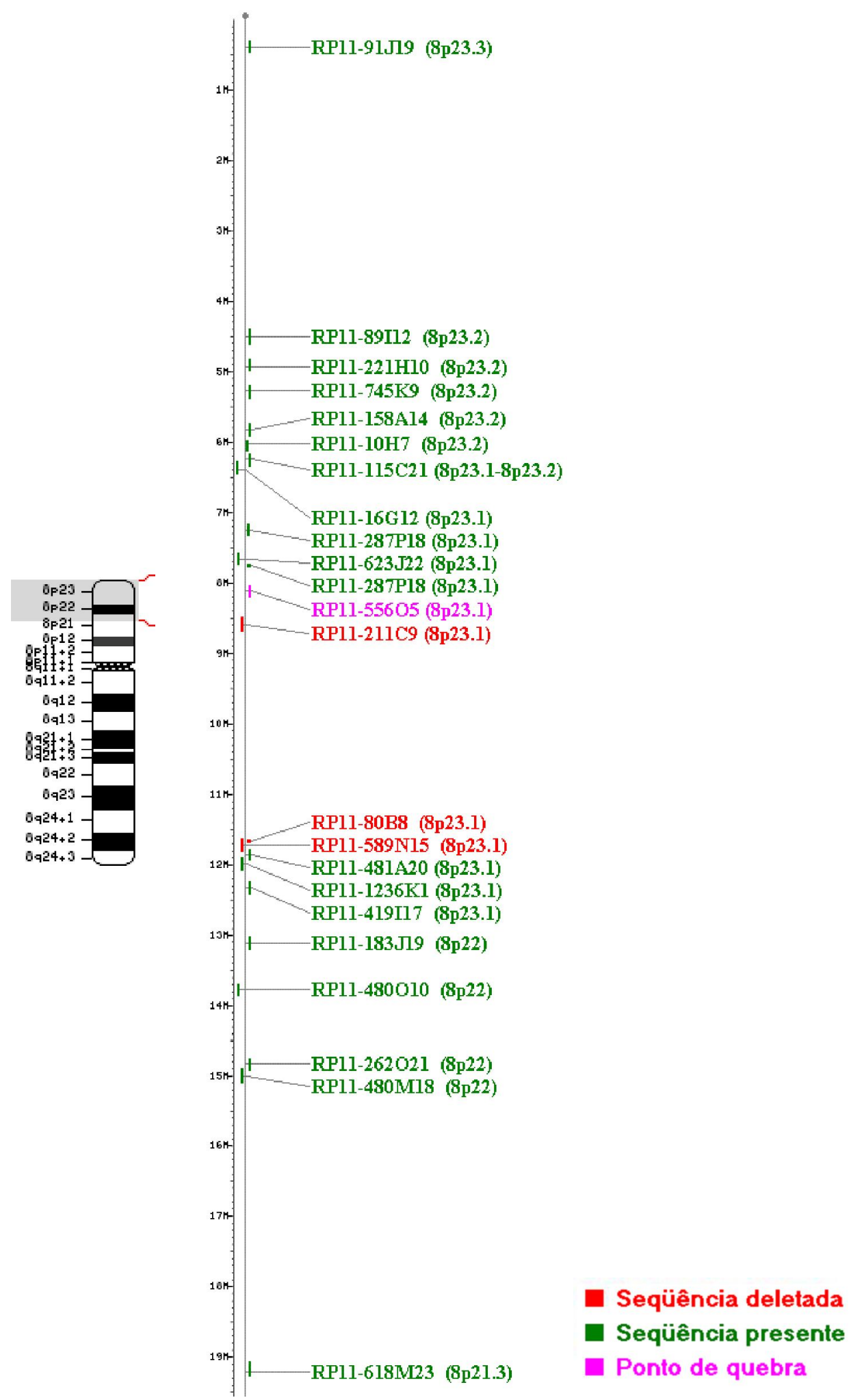

Figura 16. Delimitação do segmento do cromossomo 8 deletado. À esquerda, está um esquema do cromossomo 8 e a área em cinza representa a região em que estão mapeadas as sondas utilizadas. À direita, está o mapa da posição relativa dos BAC utilizados para delimitar os pontos de quebra (NCBI, junho de 2006). A régua indica a distância em Mb. 


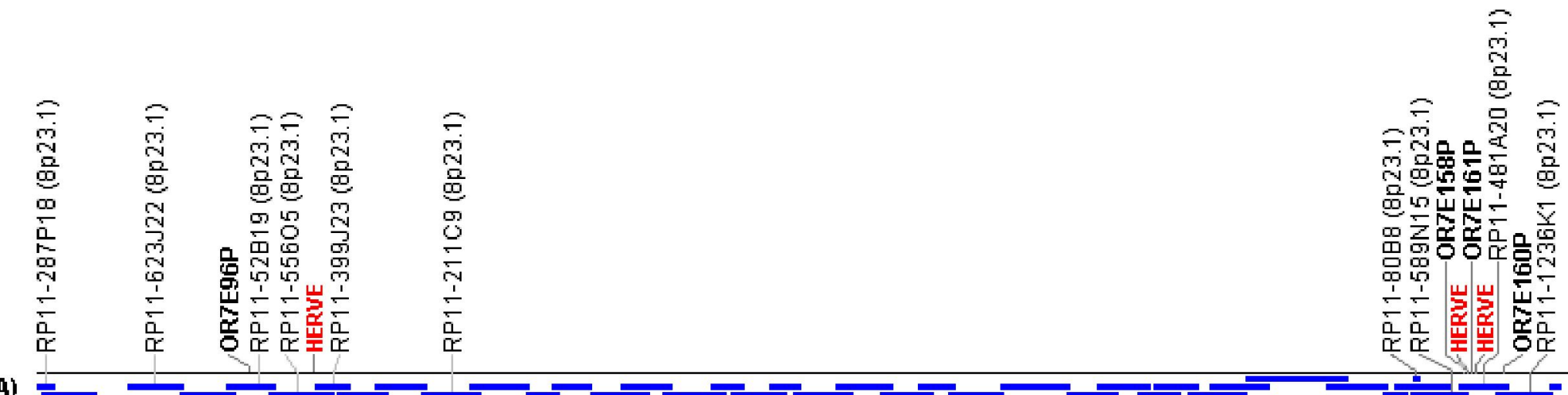

(A)

(B)

(C)

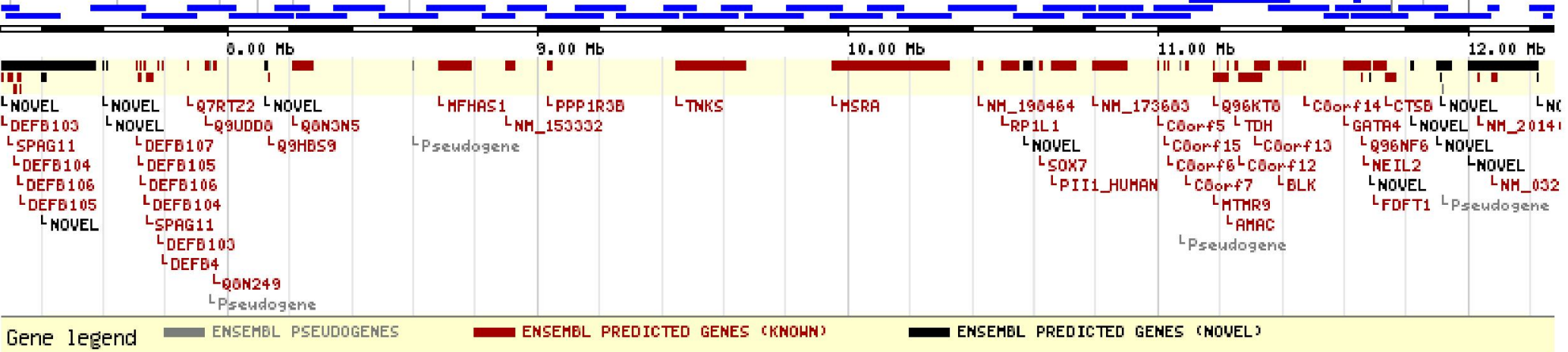

OR7E96P olfactory receptor, family 7 , subfamihy E, member 96 nseudogene

(A) Ti lepath

(B) Length

(C) Ensembl Genes

OR7E 158P olfactory receptor, family 7 , subfamily $\mathrm{E}$, member 158 pseudogene

OR7E161P olfactory receptor, family 7 , subfamily $E$, member 161 pseudogene

OR7E 160P offactory receptor, family 7, subfamily $\mathrm{E}$, member 160 pseudogene

Figura 17. Região 8p23.1 envolvida na deleção do cromossomo der(8) da Paciente 2. (A) BAC. (B) Segmento analisado. (C) Genes. Os elementos repetitivos estão em negrito e os HERVE, em vermelho (Ensembl release 32). 
Nossa hipótese foi que a deleção tivesse resultado da recombinação entre dois desses segmentos de HERVE, com a perda do material intersticial. Para testar essa hipótese, foi planejado um experimento de Southern blotting, com a intenção de detectar o fragmento de junção resultante do rearranjo.

Com o auxílio do aplicativo pDRAW32 1.0 Revision 1.1 .88 (www.acaclone.com), foi selecionada como adequada a enzima $A f l$ II, cujos sítios de corte não envolvem os HERVE (Figura 19). Dessa forma, como resultado do rearranjo, esperava-se ter quatro possíveis fragmentos. Se a NAHR ocorreu entre HERVE(A) e HERVE(B), o fragmento teria 13043 pb. Caso tenha sido entre HERVE(A) e HERVE(C), teria 9643 pb. Se foi entre HERVE(A) e HERVE(D), teria 15403 pb. Mas se foi entre HERVE(A) e HERVE(E), teria 10843 pb.

Como todas as possibilidades envolvem o $\operatorname{HERVE(A),~foi~necessário~construir~}$ uma sonda que o identificasse, levando em consideração que a enzima $A f l$ II gera um fragmento de 15847 pb, que contém $\operatorname{HERVE(A),~no~cromossomo~} 8$ normal. Para a construção da sonda por PCR, identificamos inicialmente um segmento de 1134 pb do cromossomo 8, em que, de acordo com o Ensembl (release 32), não há seqüências repetitivas. Esse segmento está contido no clone RP11-556O5 (8009046-8212456 pb) e estende-se de $50414 \mathrm{pb}$ até $51548 \mathrm{pb}$ nesse BAC, ou seja, no intervalo 8059460$8060594 \mathrm{pb}$ do cromossomo 8. Considerando que o corte da enzima Afl II ocorre em $8059570 \mathrm{pb}$, o intervalo para a escolha da sequiência da sonda ficou restrito a um segmento de 1024 pb, entre 8059570 e 8060594 pb, telomericamente a HERV(A). O par de primers utilizado (Tabela IV) para a construção da sonda amplifica um produto de $654 \mathrm{pb}$.

Nesse experimento, não obtivemos resultado que permitisse uma conclusão: não foi possível distinguir qualquer um dos fragmentos que pudesse representar o de junção (13043, 9643, 15403 ou 10843 pb), distinguível do fragmento normal (15847 pb). Entretanto, existe a possibilidade de que o fragmento de junção seja o de 15403 pb, não sendo, no experimento, distinguível do fragmento normal de $15847 \mathrm{pb}$ (banda de 16 $\mathrm{Kb}$ da Figura 20). Se este for o caso, o evento de recombinação na origem da deleção teria ocorrido entre o $\operatorname{HERVE}(\mathrm{A})$ e o $\operatorname{HERVE}(\mathrm{D})$. Assim, o segmento deletado teria $\sim 3,75 \mathrm{Mb}$, em 8p23.1. 


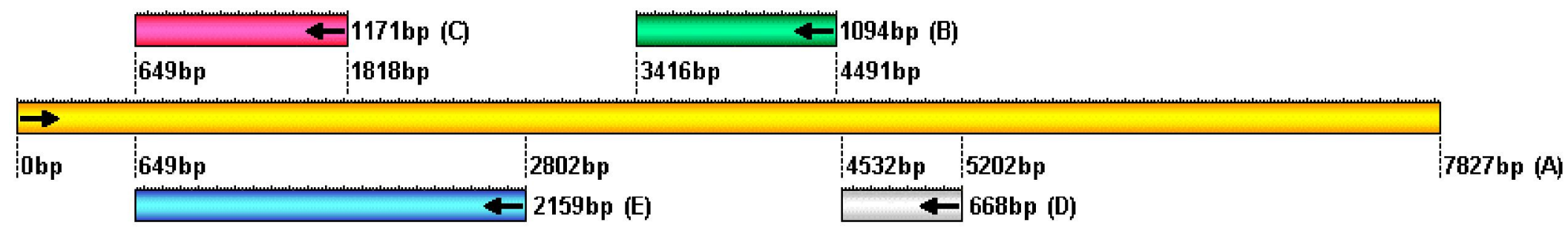

A \& B $\rightarrow$ Identities $=971 / 1090(698)$, Gaps $=5 / 1090(08)$

A $\&$ C $\rightarrow$ Identities $=1042 / 1171(888)$, Gaps $=4 / 1171(08)$

A \& D $\rightarrow$ Identities $=593 / 671(888)$, Gaps $=5 / 671(08)$

A \& E $\rightarrow$ Identities $=1925 / 2160(898)$, Gaps $=10 / 2160(08)$

Figura 18. - Esquema representando o alinhamento das seqüências de HERVE (Ensembl release 39) e o resultado do BLAST (NCBI) entre HERVE(A) e os demais, indicando o grau de similaridade entre as seqüências.

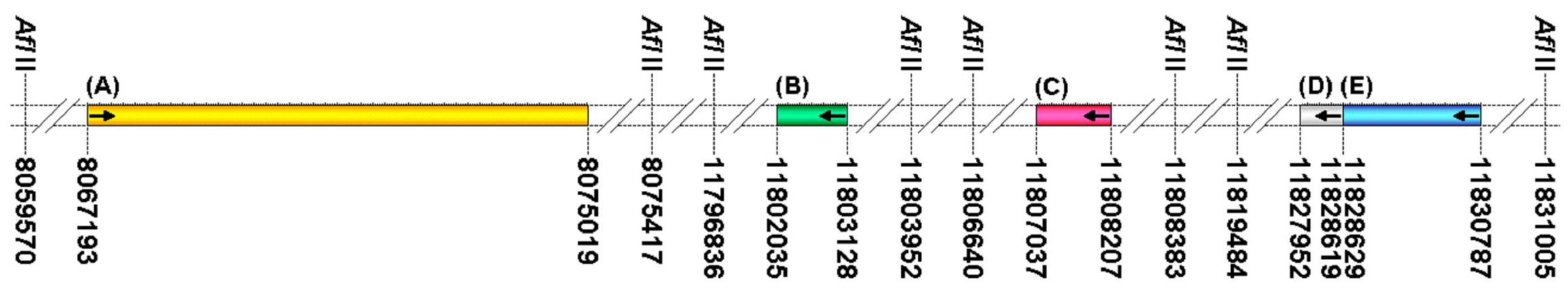

Figura 19. - Esquema representando os sítios de corte da enzima $A f l$ II entre as sequiências de HERVE, com suas posições dadas em pb do cromossomo 8

(Ensembl release 39). 
Tabela IV. - Seqüência dos primers utilizados na construção da sonda.

\begin{tabular}{|c|c|}
\hline Oligo & Seqüência $\left(\mathbf{5}^{\prime} \rightarrow \mathbf{3}^{\prime}\right)$ \\
\hline Left Primer & AGTGACTCCTCAGCGGAAAA \\
\hline Right Primer & CTGGGCCATAACCATTTGAC \\
\hline
\end{tabular}

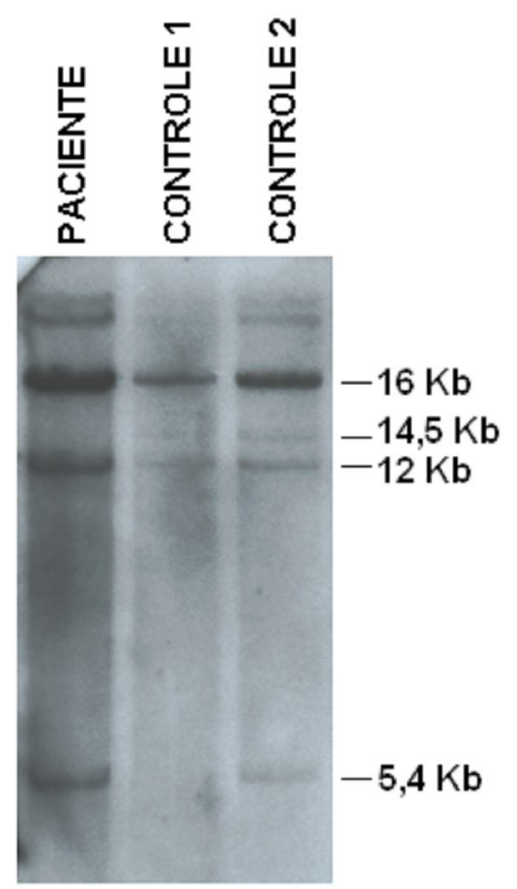

Figura 20. Southern Blot: a sonda marcada com $\left[\alpha^{32} \mathrm{P}\right]-\mathrm{dATP}$ detectou um fragmento $\sim 16 \mathrm{~kb}$, tanto no paciente como nos controles. Os demais fragmentos devem representar outros fragmentos genômicos com homologia com a sonda.

Analisamos também a deleção utilizando um tilepath array genômico do cromossomo 8 (1371 clones de BAC), construído no Nijmegen Medical Centre, Holanda. Esse conjunto representa em média uma sonda a cada $100 \mathrm{~Kb}$, cobrindo toda a extensão do cromossomo 8, que tem 146,27 Mb. Os procedimentos de hibridação foram realizados pela Dra. Ana Cristina Krepischi-Santos, pesquisadora do CNPq no LGH. As metodologias de marcação, hibridação e análise foram descritas por de Vries et al. (2005). O experimento demonstrou que a deleção é contínua, porém indicou ser maior do que havia sido delimitada por FISH, compreendendo $\sim 5,7 \mathrm{Mb}$ (Tabela V). 
Tabela V. Correspondência entre os resultados obtidos na análise da deleção 8p por tilepath array genômico do cromossomo 8 e os resultados obtidos por FISH.

\begin{tabular}{|c|c|c|}
\hline \multicolumn{2}{|c|}{ Array-CGH } & \multirow{2}{*}{$\begin{array}{c}\text { FISH } \\
\text { Resultados }\end{array}$} \\
\hline Clone & Resultado & \\
\hline RP11-485I5 & Normal & \\
\hline RP11-231L4 & Ponto de quebra & \\
\hline RP11-447A6 & del & \\
\hline RP11-738021 & del & \\
\hline RP11-594D21 & del & \\
\hline RP11-743F19 & del & \\
\hline RP11-739E3 & del & \\
\hline RP11-115E11 & del & \\
\hline RP11-55605 & del & Ponto de quebra \\
\hline RP11-435L12 & del & \\
\hline $\mathrm{RP} 11-1 \mathrm{G} 6$ & del & \\
\hline RP11-443C23 & del & \\
\hline RP11-54G22 & del & \\
\hline RP11-19J4 & del & \\
\hline RP11-18L2 & del & \\
\hline RP11-215M9 & del & \\
\hline RP11-495C9 & del & \\
\hline RP11-776B5 & del & \\
\hline RP11-341D4 & del & \\
\hline RP11-143J23 & del & \\
\hline RP11-796J3 & del & \\
\hline CTD-2339A14 & del & \\
\hline RP11-320C22 & del & \\
\hline RP11-797C19 & del & \\
\hline $\mathrm{RP} 11-732 \mathrm{H} 23$ & del & \\
\hline RP11-369G24 & del & \\
\hline RP11-112G9 & del & \\
\hline RP11-654E3 & del & \\
\hline RP11-423K3 & del & \\
\hline RP11-593D5 & del & \\
\hline $\mathrm{RP} 11-177 \mathrm{H} 2$ & del & \\
\hline RP11-787E6 & del & \\
\hline RP11-318F18 & del & \\
\hline RP11-437P14 & del & \\
\hline RP11-448A20 & del & \\
\hline RP11-582P18 & del & \\
\hline RP11-802F15 & del & \\
\hline RP11-433012 & del & \\
\hline RP11-794G6 & del & (= RP11-80B8) del \\
\hline RP11-367E11 & del & $\begin{array}{l}\text { (= RP11-481A20) } \\
\text { ponto de quebra }\end{array}$ \\
\hline RP11-350L10 & del & \\
\hline RP11-351I21 & del & \\
\hline RP11-419I17 & del & Presente \\
\hline CTD-2185F10 & del & \\
\hline RP11-801I21 & del & \\
\hline RP11-683E21 & Ponto de quebra & \\
\hline RP11-813L8 & Ponto de quebra & \\
\hline RP11-561J23 & Normal & \\
\hline
\end{tabular}

Created with novaPDF Printer (www.novaPDF.com). Please register to remove this message. 
Considerando o princípio das duas técnicas e que os segmentos discrepantes podem constituir variantes genômicas, realizamos FISH de sondas mapeadas nos segmentos discordantes (RP11-287P18, RP11-556O5, RP11-481A20, RP11-1236K1 e RP11-419I17 Figura 16) em metáfases de indivíduos com cariótipos normais. Verificamos a ocorrência: (A) de hibridação cruzada [hibridação em outros loci genômicos, incluindo a região de receptores olfativos no braço curto do cromossomo 4, que participa na translocação t(4;8)(p16;p23)], e (B) de diferença quanto ao número de cópias das seqüências entre homólogos, evidenciada por diferenças entre a intensidade dos sinais de hibridação (Figuras 21, 22 e 23).

Assim, as diferenças entre os resultados do microarray e da FISH podem ser explicadas por terem sido apontadas como deletadas sequiências que apenas devem estar presentes em menor número de cópias na Paciente 2, mas dentro da variabilidade populacional.

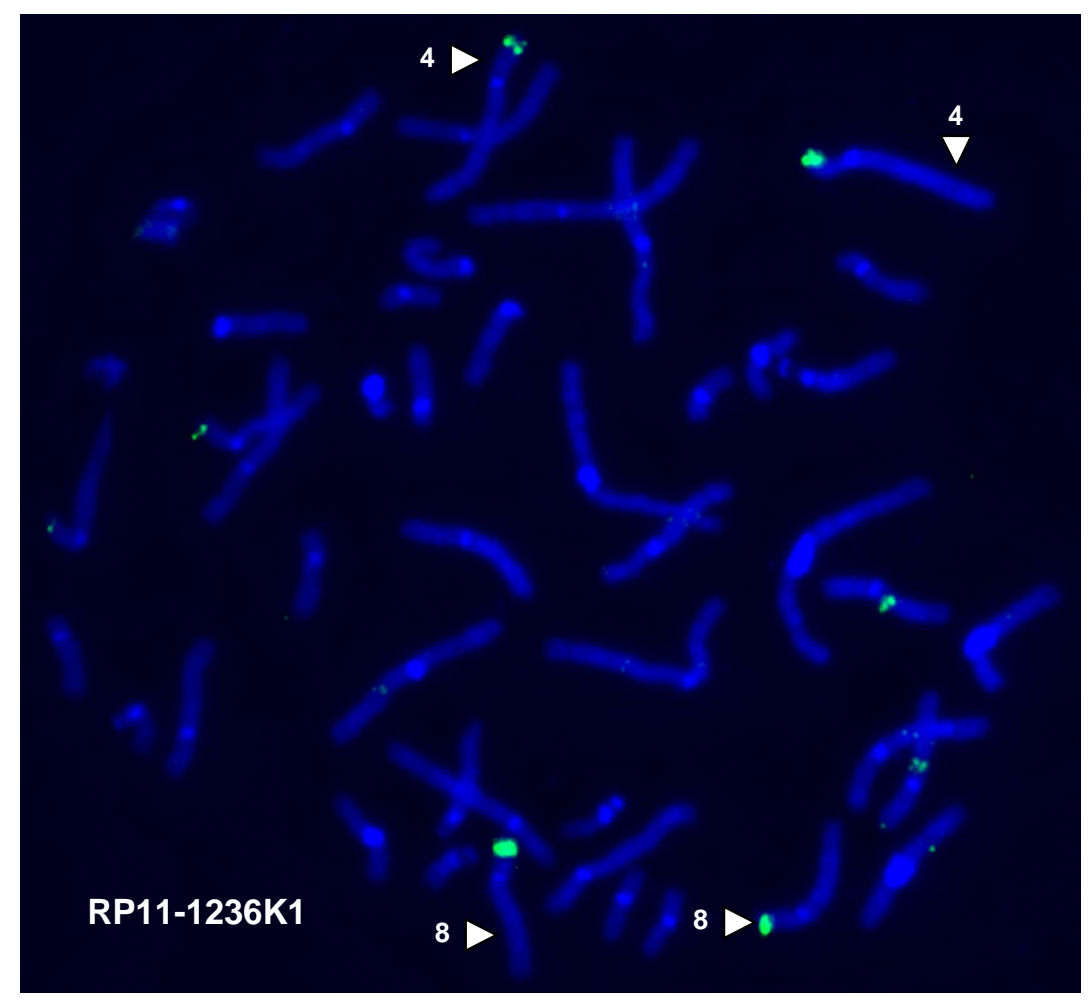

Figura 21. FISH da sonda RP11-1236K1 em metáfase de indivíduo controle, mostrando sinais de hibridação tanto no cromossomo 8 como no 4 , além de diferença na intensidade dos sinais de hibridação entre os cromossomos homólogos. 

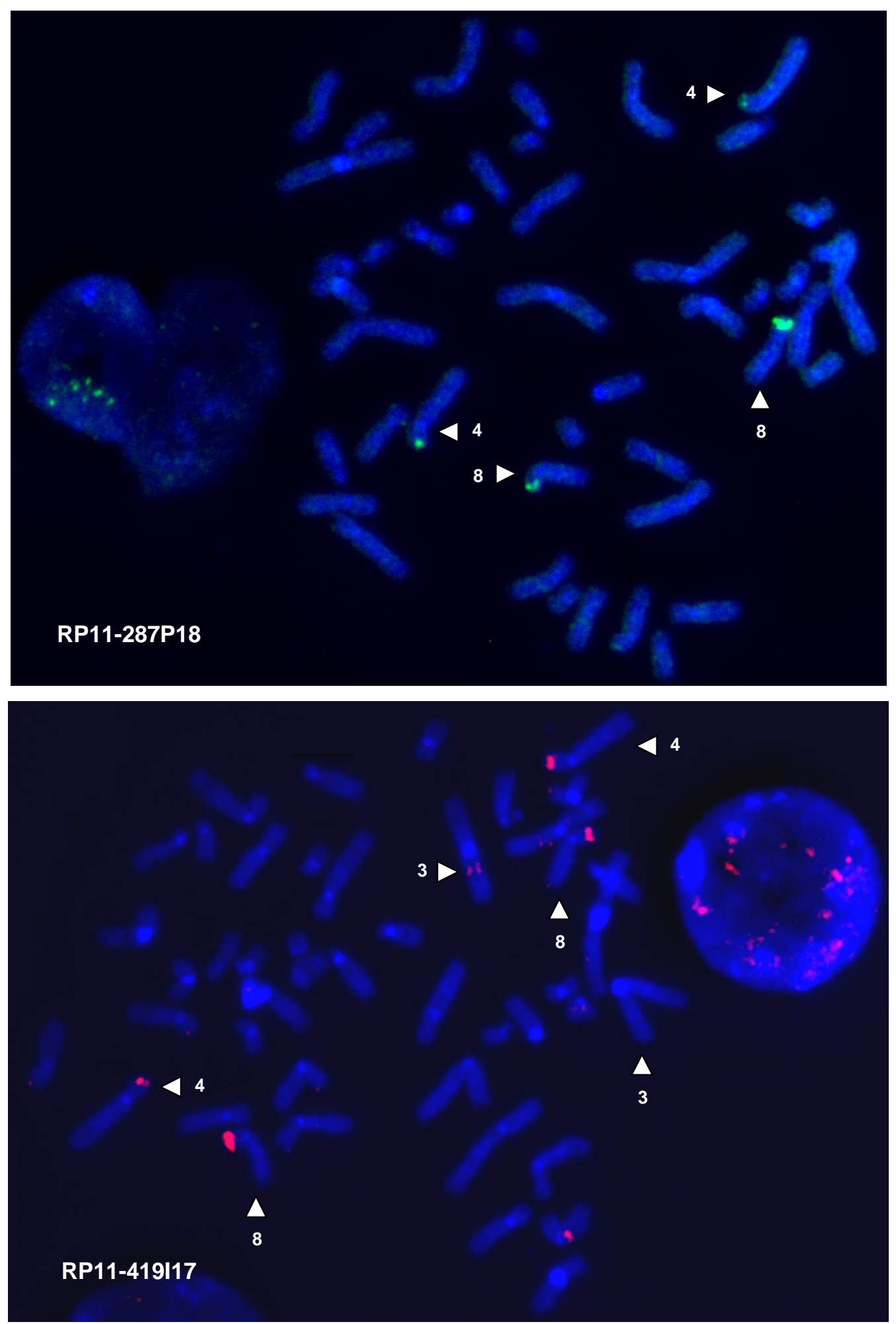

Figura 22. FISH das sondas RP11-287P18 e RP11-419I17 em metáfases e núcleos interfásicos de indivíduo controle, mostrando sinais de hibridação cruzada e variações na intensidade dos sinais de hibridação entre cromossomos homólogos. 


\section{RP11-481A20}

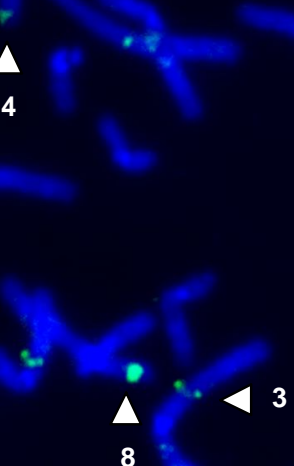

8
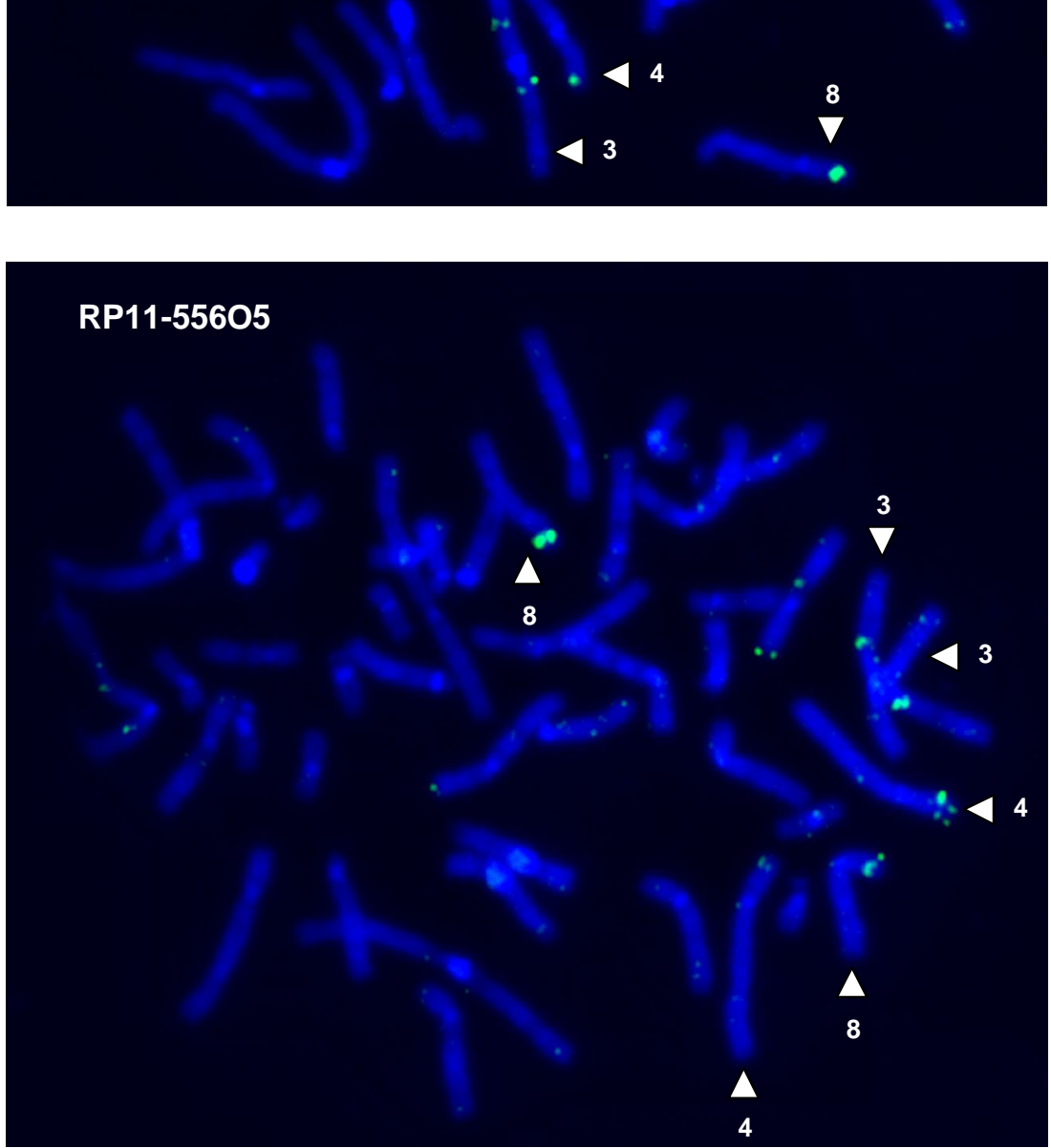

Figura 23. FISH das sondas RP11-481A20 e RP11-556O5 em metáfases de indivíduo controle, mostrando sinais de hibridação cruzada e variação na intensidade dos sinais de hibridação entre cromossomos homólogos. 


\section{IV.2.2. A ORIGEM PARENTAL DA DELEÇÃO}

Determinamos a origem parental da deleção, analisando o locus D8S550, mapeado no segmento deletado (Pacientes e Métodos, Pág. 17), no pai da paciente e em seus avós paternos. Verificamos que o avô paterno é homozigoto (alelos de 215 pb); a avó paterna é heterozigota (alelos de 197 e 211 pb) e o pai da paciente apresenta apenas um alelo de 215 pb, herdado de seu pai, demonstrando que a deleção é de origem materna (Figura 24).

Alguns estudos demonstraram que a maioria dos casos de rearranjos em $8 \mathrm{p}$ tem origem na meiose materna, sejam inversões, duplicações, deleções e translocações (Floridia et al., 1996; Giglio et al., 2001; revisão em Shaw e Lupski, 2004).

\section{IV.2.3. OS POLIMORFISMOS E A FORMAÇÃO DOS REARRANJOS DO BRAÇO CURTO DO CROMOSSOMO 8}

Em 1996, Floridia et al. estudaram 16 casos de duplicação invertida do braço curto do cromossomo 8 [inv dup(8p)]. A fim de identificar os segmentos duplicados, os autores utilizaram FISH, análise de polimorfismos de DNA por PCR e análise quantitativa por Southern blotting. Os rearranjos ocorreram sempre entre cromossomos homólogos e os pontos de quebra na extremidade distal do braço curto do cromossomo 8 foram localizados nos mesmos segmentos cromossômicos. Os autores sugeriram a presença, nesses segmentos, de seqüências repetidas com orientação invertida, cujo emparelhamento na meiose favoreceria a ocorrência de recombinação, levando à formação de dicêntricos. Quebras centroméricas originariam os cromossomos 8 com duplicação invertida.

Atualmente, sabe-se que 8p23.1 é uma região cromossômica especialmente rica em elementos repetidos que freqüentemente participam de rearranjos. Aí ocorrem duas regiões de repetição de receptores olfativos (ORR), distantes $5 \mathrm{cM}$ uma da outra, como também aglomerados de genes anti-microbiais de beta-defensinas (DEF). Esses genes (DEFB4, DEFB103 e DEFB104) são polimórficos quanto ao número de cópias, podendo um cromossomo ter uma a oito cópias (Hollox et al., 2003). 
Um em cada quatro indivíduos da população geral é portador de uma inversão polimórfica do segmento entre as duas ORR (revisão em Hollox et al., 2003). Essa inversão polimórfica, que não é possível ser identificada na análise cromossômica convencional, estaria relacionada com a formação de duplicações invertidas de 8p (como aquelas descritas por Floridia et al., 1996), por deleções de 8p (Devriendt et al.,1999; Pehlivan et al., 1999) por marcadores supra-numerários [+der(8)(8p23.1-pter)], por duplicação intersticial de 8p23 e pela tranlocação t(4;8)(p16;p23) (revisão em Giglio et al., 2001; Sugawara et al., 2003).

Giglio et al. (2001) estudaram uma del(8p) cujo ponto de quebra distal localiza-se próximo ao marcador D8S1706 (6928157-6928525 pb), que está mais distal do que o ponto de quebra do caso do presente estudo, que localizamos no clone RP11-556O5 (8009071$8212432 \mathrm{pb}$ ). Já o ponto de quebra proximal foi identificado por Giglio et al. (2001) próximo ao locus D8S1130 (11871345-11871658 pb), que, de acordo com o banco de dados da UCSC, está contido no clone RP11-481A20 (11779087-11929409 pb), no ponto de quebra proximal da deleção de nosso estudo. Giglio et al. (2001) sugeriram que os aglomerados de genes de receptores olfativos (OR) podem ter servido de substrato para a formação dos rearranjos em $8 p$ estudados em seu trabalho e nos de outros estudos também. Entretanto, não fizeram uma análise molecular detalhada que definisse exatamente os pontos de quebra em relação a esses genes.

Para caracterizar a inversão polimórfica em 8p23, Sugawara et al. (2003) construíram um mapa físico, baseado em BAC e PAC, que cobriu os 4,7 Mb da inversão e suas regiões flanqueadoras. Identificaram uma LCR em cada ponto de quebra: a distal, de $\sim 1,3 \mathrm{Mb}$, entre os clones CTB-415D8 (atualmente não encontrado nos bancos de dados como estando no cromossomo 8) e RP11-556O5; a outra, proximal, de $\sim 0.4 \mathrm{Mb}$, entre os clones RP11-351I21 e RP11-303G3 - 12233358-12611672 pb. Os autores compararam esses dois blocos e verificaram elevada similaridade de seqüência, com uma complexa configuração, em que fragmentos apresentam orientações direta e invertida (Figura 25).

Ciccone et al. (2006) descreveram um mosaico 46,XX,psu $\operatorname{dic}(8)(\mathrm{p} 23.2) / 46, \mathrm{XX}, \mathrm{del}(8)(\mathrm{p} 23.1)$, em que as duas linhagens celulares ocorriam com freqüências de $60 \%$ e $40 \%$, respectivamente; a peculiaridade é que a deleção compreendia duas regiões não contíguas, como resultado de uma inversão polimórfica de 8 p. A clássica 
inversão polimórfica do braço curto do cromossomo 8 foi identificada no pai da paciente por FISH dos clones RP11-399J23 e RP11-589N15. A análise de microssatélites mostrou a ausência de alelos paternos na região deletada na paciente e permitiu concluir que as alterações nas duas linhagens celulares se originaram de um mesmo cromossomo 8 paterno, formando-se inicialmente um cromossomo dicêntrico. Por CGH-array, os autores demonstraram também que a região distal de 8 p estava deletada em ambas as linhagens. Por FISH, definiram os pontos de quebra no cromossomo dicêntrico e no cromossomo com a deleção terminal. O pseudodicêntrico apresentava deletada a região do telômero ao clone RP11-1K11 (4,7 Mb; o ponto de quebra não coincide com os dois aglomerados de OR em 8p23.1), enquanto o resto do cromossomo estava duplicado. Com relação à linhagem $\operatorname{del}(8 \mathrm{p})$, uma das regiões deletadas $(6,7 \mathrm{Mb})$ estendia-se do telômero ao clone RP11-5E15, enquanto que o segmento entre os clones RP11-399J23 (não deletado) e RP11-62H7 estava presente; a outra deleção no mesmo cromossomo localizava-se entre RP11-429B7 e RP11589N15 (deletado), enquanto o resto do cromossomo não mostrou alteração, do clone RP11-813L8 até 8q-ter.

A deleção que estudamos tem aproximadamente 3,9 Mb, pois o ponto de quebra distal está localizado na seqüência de RP11-556O5 (8009046-8212456 pb) e o proximal está provavelmente no segmento de superposição dos clones RP11-589N15 e RP11481 A20 (11778967-11803128 pb). Portanto, os pontos de quebra da deleção estão contidos na região polimórfica da inversão definida por Sugawara et al. (2003). Quanto à deleção del(8p), que Ciccone et al. (2006) relacionaram à inversão polimórfica envolvendo blocos de OR, o ponto de quebra da deleção distal e o ponto de quebra proximal da deleção proximal não estão mapeados de forma precisa, mas existe a possibilidade de estarem nos mesmos clones em que localizamos os pontos de quebra na Paciente 2.

A análise in silico dos segmentos envolvidos na deleção que estudamos nos permitiu verificar a existência de segmentos de homologia entre as seqüências dos BAC que contêm os pontos de quebra proximal e distal (Figura 25). Esses segmentos são constituídos por seqüências de retrovírus endógenos humanos (HERV) do grupo E: HERVE. Na seqüência do BAC RP11-556O5 (parcialmente deletado) existe um grande HERVE de 7826pb, e no BAC RP11-481A20 (presente) existem dois blocos que contém HERVE, um de 2158pb e outro de 4508pb. Além de HERVE, o BAC RP11-481A20 
também apresenta seqüências de regiões de receptores olfativos (ORR) e defensinas (DEF). Entretanto, não há ORR e nem DEF na seqüência do BAC RP11-556O5.

Os HERV representam rastros de infecções retrovirais em células germinativas ancestrais, constituindo de 1 a $8 \%$ do genoma humano. Inserções e deleções de retrovírus podem mudar não só a estrutura dos genes e, conseqüentemente, de seus produtos, mas também sua regulação. Além disso, eles podem afetar a estabilidade do genoma pela introdução de hotspots recombinantes (revisão em Sverdlov, 2000; Hughes e Coffin, 2001). A alta homologia que detectamos entre as HERV que estão mapeadas nos pontos de quebra da deleção que estudamos sugere que essas seqüências tenham servido de substrato para recombinação, originando o rearranjo.

Levando em consideração o estudo de Floridia et al. (1996), em que é demonstrado que as inv $\operatorname{dup}(8 \mathrm{p})$ têm origem na meiose materna, Giglio et al. (2001) investigaram a inversão polimórfica em 8 p em oito mães de pacientes com inv dup(8p) e em uma mãe de paciente com $+\operatorname{der}(8 \mathrm{p})$. Foram realizadas FISH em cromossomos metafásicos de todas elas, com duas sondas (GS173o4 e GS257o3) que limitam as regiões dos blocos de repetição, demonstrando que a região estava invertida em um dos homólogos de todas elas. Entretanto, só puderam verificar a origem materna do rearranjo em um dos pacientes. A mesma inversão submicroscópica foi encontrada em heterozigose em 19 (26\%) de 72 indivíduos controle descendentes de europeus (freqüência alélica de 13\%). Os autores sugeriram que a inversão em heterozigose geraria susceptibilidade aos rearranjos em 8p.

Com a intenção de estimar a proporção da inversão polimórfica em 8p23 na população normal japonesa, Sugawara et al. (2003) realizaram FISH de dois clones localizados dentro da inversão, RP11-399J23 e RP11-589N15, em 50 pessoas, revelando 28 homozigotos quanto ao cromossomo 8 sem inversão, 17 heterozigotos e cinco homozigotos quanto à inversão. Assim, a freqüência do alelo invertido nessa amostra da população japonesa é de $27 \%$.

Nossa paciente herdou a deleção de seu pai e essa deleção se originou num cromossomo materno. Realizamos FISH de dois clones mapeados dentro da região de inversão, RP11-211C9 (distal) e RP11-80B8 (proximal), e detectamos a inversão em homozigose não somente na avó da paciente, mas também em seu avô e em um indivíduo controle; num segundo indivíduo controle, a inversão estava em heterozigose (Figura 26). 
Como o segmento invertido inclui os blocos de HERVE, a orientação entre eles não fica alterada. Pela análise in silico, não conseguimos visualizar o mecanismo pelo qual a inversão pudesse colocar os HERVE em mesmo sentido de orientação e levar à perda de quase $4 \mathrm{Mb}$ por recombinação não alélica entre eles. Os HERVE que participariam da recombinação continuam em sentidos opostos mesmo nos cromossomos com a inversão. Nossa análise também não identificou outras seqüências que indicassem que a homozigose quanto à inversão pudesse favorecer a ocorrência da deleção. Emanuel et al. (2001) propuseram um modelo para a formação de deleção que considera o pareamento de seqüências invertidas num mesmo cromossomo, formando uma alça de segmentos não pareados, que gera a perda do trecho contido nela. Esse pode ter sido o mecanismo de formação da deleção em nossa paciente, em que os HERV contidos nas sequiências dos pontos de quebra serviriam de substrato para o pareamento intracromossômico e a formação da alça correspondente ao segmento deletado.

O fato de termos analisado quatro indivíduos não consangüíneos, não japoneses e encontrado três homozigotos quanto à inversão e um heterozigoto nos chamou a atenção, pois a frequiência esperada de homozigotos na população descendente de europeus é de 1,7\% (Giglio et al., 2001). Apesar dos desvios que uma amostra pequena pode trazer, validamos esses resultados, usando outra combinação de clones: RP11-589N15 (proximal) e RP11-399J23 (distal), ambos contidos na região da deleção (Figura 27), confirmando os resultados anteriores. Achamos que é interessante aumentar o tamanho amostral para verificar se a tendência continua, como uma característica de nossa população. 

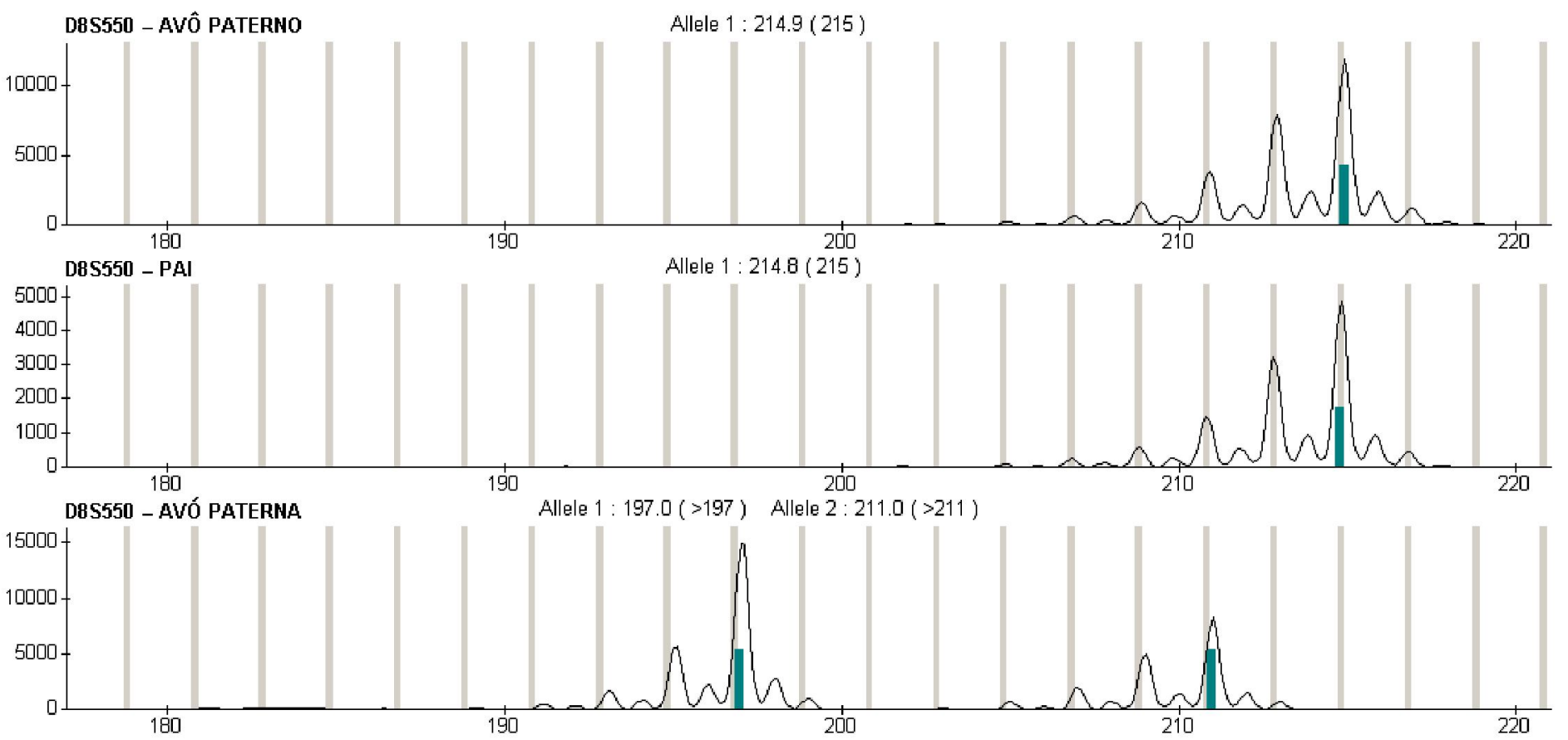

Figura 24. Determinação da origem materna da deleção por meio da análise do locus de microssatélite D8S550, mapeado no segmento deletado. O pai da paciente, também portador da deleção, possui um único alelo de 215 pb, herdado de seu pai, que tem cariótipo normal. 


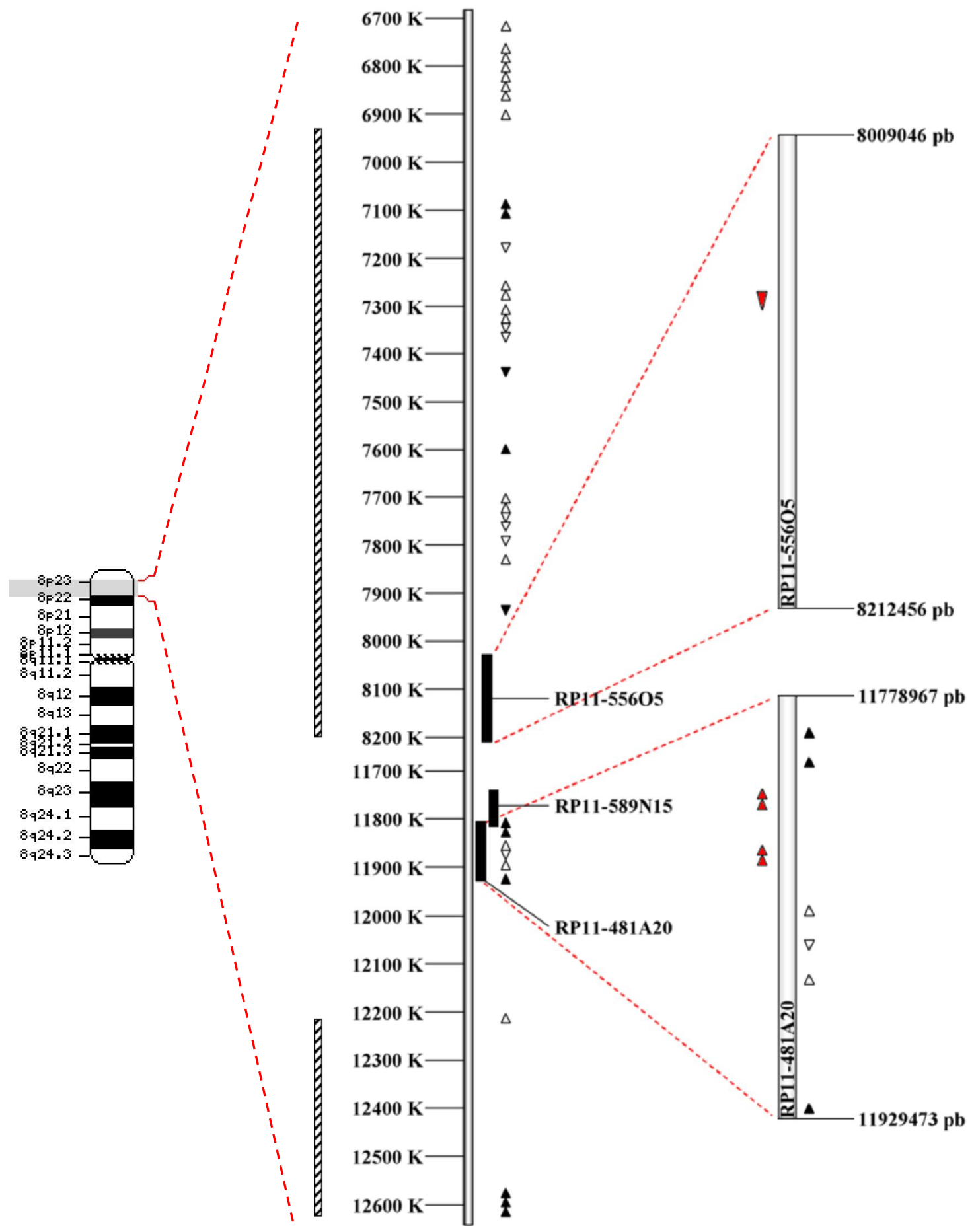

Figura 25. Mapa da região do cromossomo 8 em que estão mapeados os clones que contém os pontos de quebra da del(8) (RP11-556O5 e RP11-589N15/RP11-481A20). As cabeças de seta indicam a orientação das seqüências de receptores olfativos (pretas), de defensinas (brancas) e de HERVE (vermelhas). As barras verticais listradas representam as regiões definidas por Sugawara $e t$ al. (2003) como locais de quebra que originam a inversão polimórfica. A régua indica a distância em Kb (Ensembl, release 44). 


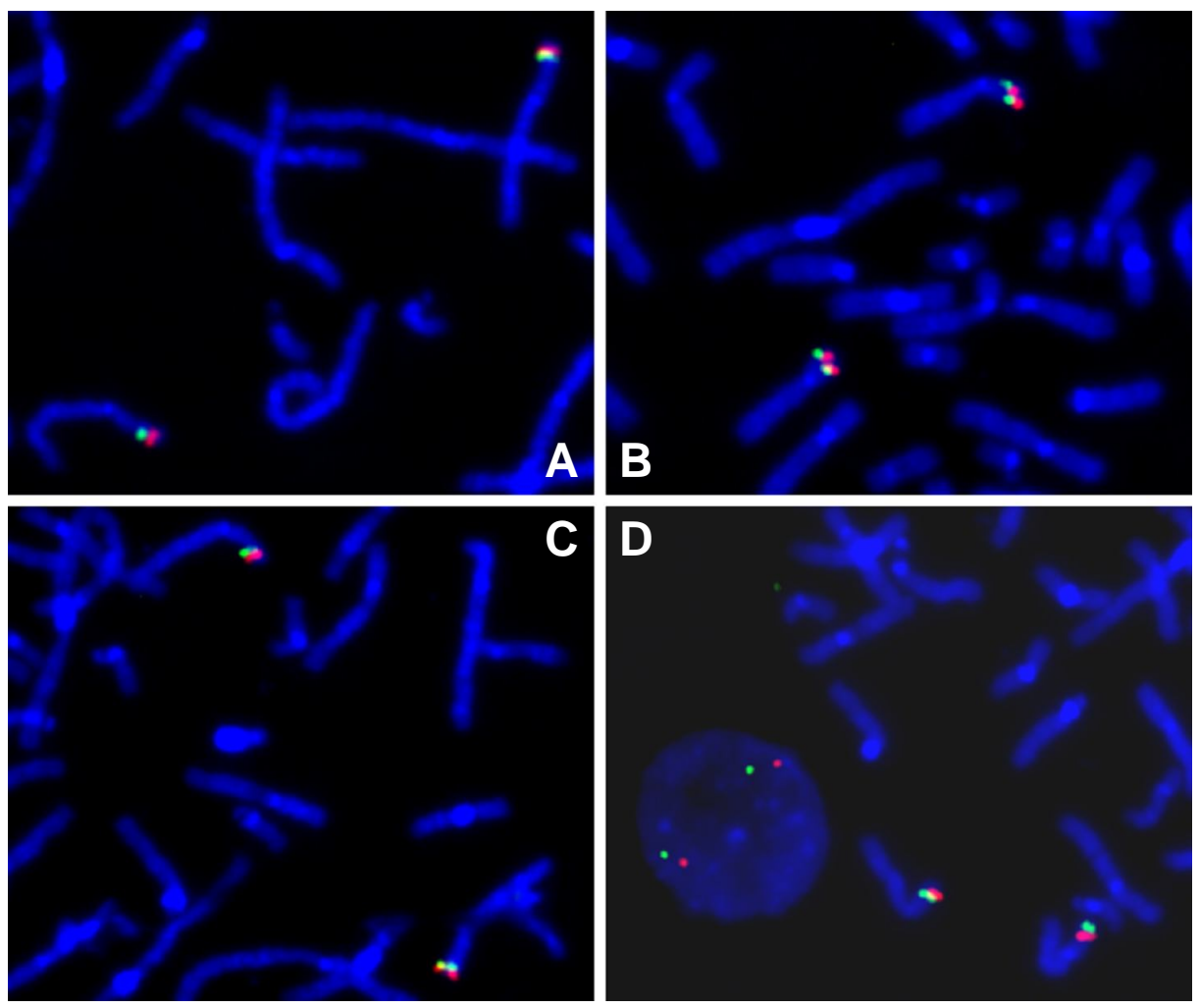

Figura 26. FISH das sondas RP11-80B8 (proximal; vermelha) e RP11- 211C9 (distal; verde) em metáfases (A) da avó paterna da Paciente 2, (B) do avô paterno, (C) do indivíduo Controle 1 e (D) do indivíduo Controle 2. Os resultados mostram que a inversão está em homozigose em A, B e C e em heterozigose em D.

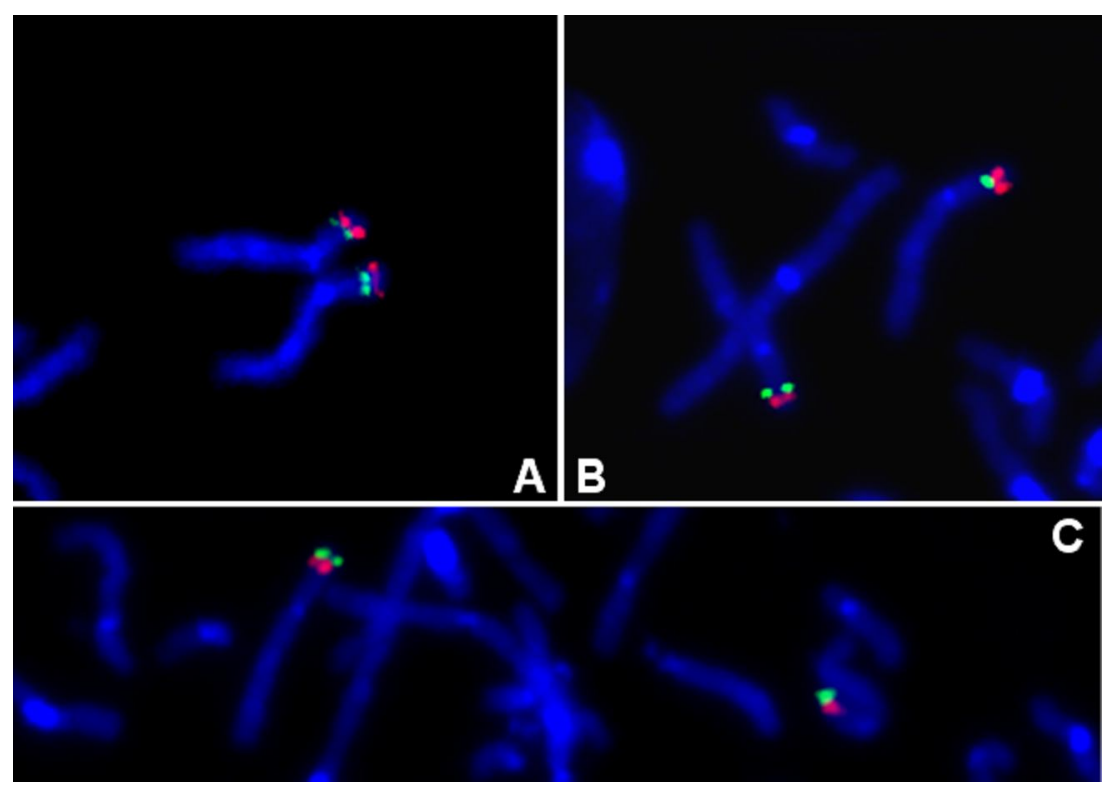

Figura 27. FISH das sondas RP11-589N15 (proximal; vermelha) e RP11-399J23 (distal; verde) em metáfases (A) da avó paterna da Paciente 2, (B) do avô paterno e (C) de um indivíduo controle não portador da inversão. Confirmamos a presença da inversão em homozigose nos avós paternos da Paciente 2. 


\section{IV.2.4. O QUADRO CLÍNICO DE DELEÇÕES DO BRAÇO CURTO DO CROMOSSOMO 8}

Anormalidades do braço curto do cromossomo 8 estão associadas a um quadro clínico de atraso de desenvolvimento e malformações congênitas (revisão em Engelen et al., 1995; Brooks et al., 1998; Yenamandra et al., 1999). A Tabela VI mostra as características clínicas de pacientes com deleções parciais do braço curto do cromossomo 8. O quadro caracteriza-se por retardo de crescimento, microcefalia, defeitos cardiovasculares, retardo mental leve, comprometimento importante da fala, hiperatividade e comportamento impulsivo. A gravidade da deficiência mental e a ocorrência de microcefalia parecem estar relacionadas à extensão da deleção.

O comportamento característico, com hiperatividade de manifestação precoce e comportamento impulsivo descritos por Fryns et al. (1989), Claeys et al. (1997) e Devriendt et al. (1999), também foi diagnosticado na Paciente 2. Nossa paciente, entretanto, nunca apresentou convulsões, uma característica descrita em alguns afetados pela síndrome de del(8p) relatada por esses autores.

Os defeitos cardíacos congênitos (CHD) mais freqüentes nos portadores da deleção são os de septo atrioventricular (AVSD), mas outros podem ser encontrados. A associação consistente de AVSD com a deleção distal de 8p indica que a região 8p23 contém gene(s) que está(ão) envolvido(s) no desenvolvimento cardíaco (revisão em Devriendt et al., 1999; Pierpont et al., 2000).

Uma revisão das anomalias cromossômicas em pacientes com CHD sugere que 8p23.1 é uma região crítica. Por meio de FISH e da análise de marcadores, a região crítica associada à AVSD foi localizada em um segmento de 5-cM flanqueado por D8S1706 e WI8327 distalmente e D8S1825 na região proximal. O gene GATA4, que codifica um fator de transcrição do tipo zinc finger, relacionado com desenvolvimento cardíaco, está localizado em 8p23.1. Tanto deleções quanto duplicações invertidas em 8p23.1 têm sido vistas em pacientes com defeitos cardíacos. Essas alterações incluem canal atrioventricular (AV), defeitos de septos atrial e ventricular (ASD, VSD), ventrículo direito com dupla saída (DORV - double outlet right ventricle), dextrocardia, estenose pulmonar (OS) e hipoplasia da parte esquerda do coração (revisão em Pehlivan et al., 1999; Pierpont et al., 2000). 
O estudo de Devriendt et al. (1999) abrangeu pacientes com del(8p), em que a extensão das deleções foi determinada pela combinação da citogenética clássica, FISH e análise de marcadores polimórficos de DNA. Com exceção de uma grande deleção terminal, todas as deleções eram intersticiais. Em cinco pacientes, uma mesma deleção de $\sim 6 \mathrm{Mb}$ foi encontrada. Um paciente sem defeito cardíaco ou microcefalia, mas com deficiência mental leve e comportamento característico tinha uma deleção menor, contida no intervalo de cerca de $6 \mathrm{Mb}$. Dois pacientes sem defeitos cardíacos tinham deleções intersticiais mais proximais, que não tinham sobreposição com a região de aproximadamente $6 \mathrm{Mb}$. Essas informações levaram os autores a definir regiões críticas para microcefalia e problemas cardíacos (HDCR8p), correspondendo ao segmento de $6 \mathrm{Mb}$. Os autores mostraram que o gene GATA4 estava deletado em todos os seus pacientes com defeito cardíaco e, conseqüentemente, era um candidato a estar relacionado com CHD. Interessantemente, o ortólogo do gene humano GATA4 está envolvido na morfogênese cardíaca no camundongo.

Pehlivan et al. (1999) investigaram a ocorrência de deleção GATA4 em cinco pacientes com deleção intersticial de 8p23.1, por meio de FISH. Quatro indivíduos que apresentavam CHD tinham deleção de GATA4 em heterozigose. O gene GATA4 não estava deletado em um quinto paciente que não tinha anomalias cardíacas. Por outro lado, análise por FISH de 48 indivíduos com CHD e cariótipos normais não detectou deleções crípticas de GATA4. Esses dados indicam que a deleção do gene GATA4 está relacionada com a presença de CHD nos portadores de deleções intersticiais em 8p23.1.

Garg et al. (2003) mostraram, em uma grande genealogia, ligação entre defeitos de septo cardíaco e a região 8p22-23. Uma mutação sem sentido (G296S) em GATA4 foi encontrada em heterozigose em todos afetados da família, mas não nos indivíduos controle. Essa mutação resulta na diminuição da afinidade de ligação ao DNA e da atividade transcricional de Gata4. Além disso, a mutação anulou uma interação física entre Gata4 e TBX5, uma proteína cuja alteração é responsável por um subconjunto de defeitos de septo cardíaco que aparecem associados a outros sinais clínicos. Em uma segunda família, Garg et al. (2003) identificaram uma mutação em GATA4 (E359del), que é inativa transcricionalmente e que segregou com defeitos de septo cardíaco. Esses resultados 
indicam a alteração de GATA4 como uma causa genética de defeitos de septo cardíaco humanos, talvez através da interação com TBX5.

Os dois pacientes do estudo de Devriendt et al. (1999) portadores de deleções menores de 8p23.1, mas contidas no intervalo de cerca de $6 \mathrm{Mb}$ que abrange a região crítica para microcefalia e problemas cardíacos, embora não apresentassem essas duas malformações, tinham o fenótipo comportamental. Essa observação sugere que as alterações comportamentais estejam associadas a uma sub-região desse segmento de $6 \mathrm{Mb}$, definida pelo paciente portador da menor deleção. Uma vez que esse paciente também tinha um discreto atraso de desenvolvimento, essa sub-região também pode conter um ou mais loci que contribuem para o desenvolvimento. Ainda não se sabe se o fenótipo comportamental e o atraso de desenvolvimento são causados pela haploinsuficiência do(s) mesmo(s) gene(s).

A deleção da Paciente 2, de cerca de $4 \mathrm{Mb}$, está contida no segmento de cerca de $6 \mathrm{Mb}$ descrito por Devriendt et al. (1999) como a região crítica associada a microcefalia e a defeito de septo átrio-ventricular (AVSD). Ela possui múltiplas anomalias congênitas que são características da síndrome de del(8p), como microcefalia, retardo mental e de crescimento, hiperatividade e malformação cardíaca. A haploinsuficiência do gene GATA4 deve ser responsável pela comunicação inter-atrial que apresentava e que foi corrigida cirurgicamente. O quadro clínico do genitor da paciente é claramente semelhante ao dela. Ele tem deficiência mental, não tendo conseguido alfabetizar-se e era hiperativo quando criança, segundo relato de sua genitora. Nele, entretanto, não foi diagnosticado defeito cardíaco, indicando a expressividade variável da deleção do gene GATA4. 
Tabela VI. Características clínicas dos pacientes com deleção em 8p.

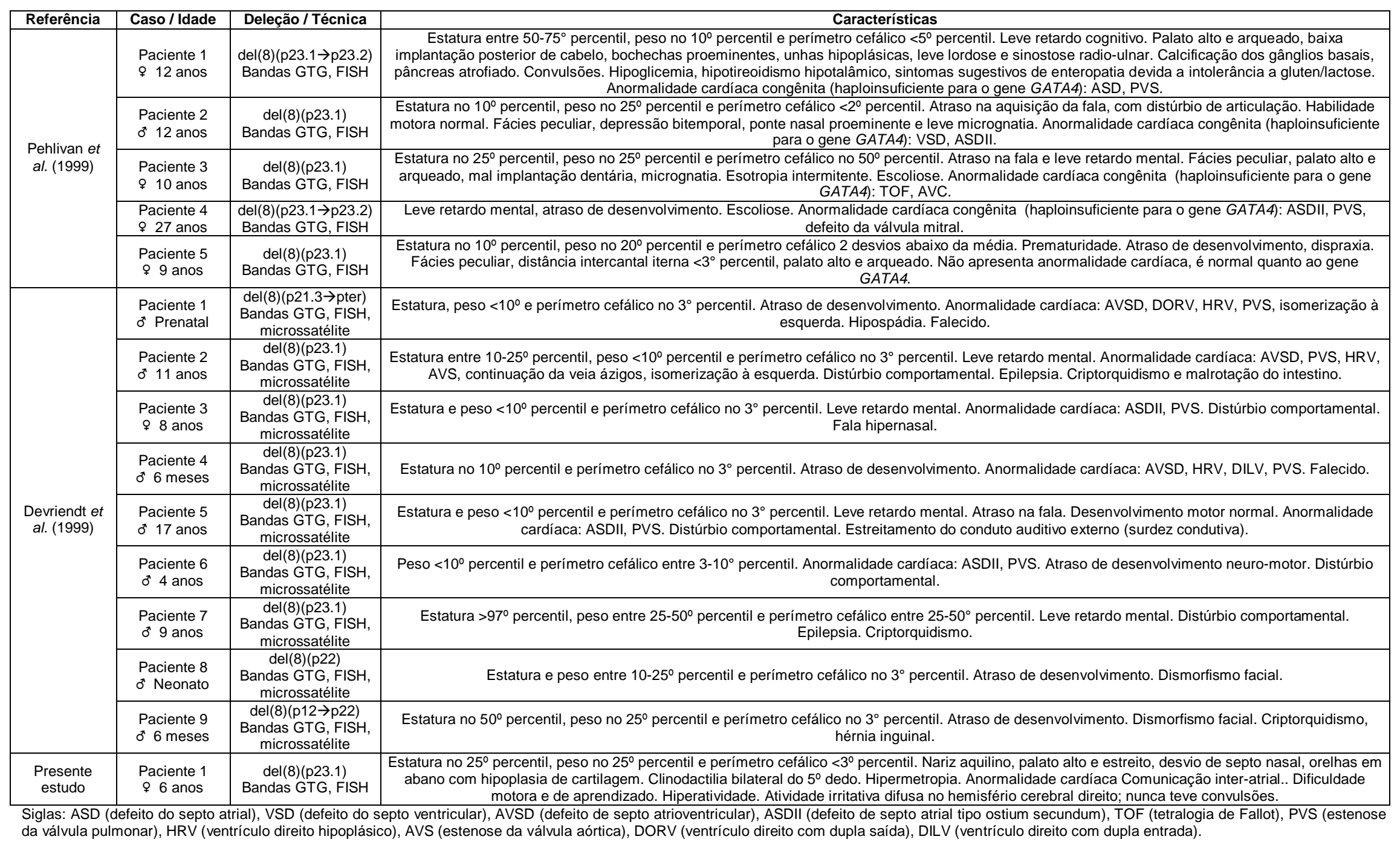




\section{SUMÁRIO E CONCLUSÕES}

As alterações cromossômicas estruturais associadas a fenótipos clínicos oferecem a oportunidade de identificação de genes cujas mutações possam estar determinando essas patologias, tendo em vista a possibilidade de que esses genes podem ter sido alterados pelas quebras ou ter o número de cópias modificado. Um número cada vez maior de evidências aponta para a participação de certas sequiências do genoma na formação de rearranjos cromossômicos recorrentes e não recorrentes. Neste trabalho, estudamos duas deleções cromossômicas detectadas em indivíduos com retardo mental associado a sinais clínicos. O objetivo foi determinar que mecanismos originaram esses rearranjos e como a perda ou quebra dos segmentos cromossômicos está relacionada com o fenótipo dos portadores. A caracterização das seqüências nos pontos de quebra e junção desses rearranjos é fundamental para a compreensão dos mecanismos de formação das alterações cromossômicas. A delimitação precisa dos segmentos deletados é necessária para a correlação com o quadro clínico. Para isso, este trabalho aliou o estudo cromossômico por hibridação in situ fluorescente (FISH) à análise do DNA.

\section{Deleção do braço curto do cromossomo $X$}

O Paciente 1, com quadro de deficiência mental sindrômica, tem uma deleção no braço curto do cromossomo X, não detectável no exame cromossômico após bandamento $\mathrm{G}$ (550 bandas). A del(X)(p11) foi diagnosticada pelo screening genômico por hibridação genômica comparativa (CGH-array). A deficiência mental está presente na família seguindo um padrão de herança ligada ao $\mathrm{X}$ recessiva. A deleção foi detectada num tio materno do paciente, portador de quadro clínico semelhante, e em heterozigose nas genitoras dos pacientes.

Delimitamos os pontos das quebras cromossômicas que originaram a deleção, por meio de FISH de segmentos clonados em BAC: situam-se em Xp11.23, na seqüência dos clones adjacentes RP1-54B20 e RP11-38O23, parcialmente deletados e que e se sobrepõem em apenas 100 pb. A genotipagem de microssatélites na região delimitada contribuiu para detalhar o mapeamento dos pontos de quebra da deleção. 
A análise in silico dos segmentos que contêm os pontos de quebra mostrou que nos dois clones (RP1-54B20 e RP11-38O23) há um segmento de $\sim 16 \mathrm{~Kb}$, com identidade superior a 95\%, distantes $106 \mathrm{~Kb}$ um do outro. No bloco A, região de $\sim 16 \mathrm{~Kb}$ da sequiência do clone RP1-54B20, há um único gene, o SPACA5. No bloco $\mathrm{B}$, região de $\sim 16 \mathrm{~Kb}$ da seqüência do clone RP11-38023, há um único gene, o SPACA5B.

Por meio de PCR, determinamos a presença do início do Bloco A e do final do Bloco B, além da ausência do final do Bloco A e do início do Bloco B. A análise de polimorfismos de um único nucleotídeo (SNP) característicos de cada bloco mostrou que o paciente apresenta todos os polimorfismos estudados do Bloco B e nenhum do A. O SNP mais distal estudado estava a 1189 pb do início dos blocos, no intron 1-2 de um dos transcritos do gene SPACA5, estando apenas a variante do Bloco B presente no paciente. Assim, o ponto de quebra proximal pôde ser localizado em um segmento de 1486 pb, enquanto que o ponto de quebra distal pôde ser localizado em um segmento de 1292 pb. Os segmentos delimitados para a quebra contêm 1189 pb dos blocos de repetição, com 99\% de identidade de seqüência no gene SPACA5 e na seqüência do bloco proximal que precede o gene $S P A C A 5 B$. A recombinação homóloga não alélica entre essas seqüências similares pode, portanto, ter sido o mecanismo que originou a deleção. Há quatro genes candidatos mapeados na região delimitada para a deleção: SSX6, SPACA5, ZNF182 e ZNF630. SSX6 não aparece com candidato para a deficiência mental, pois se expressa apenas em linhagens tumorais. É provável que o gene SPACA5 tenha sofrido recombinação não alélica com a seqüência que precede o gene $S P A C A 5 B$. Um efeito clínico de um novo produto gênico poderia ocorrer, mas desconhecendo-se a função desse gene e havendo a possibilidade de complementação funcional pelo produto do gene $S P A C A 5 B$ não nos é possível ir além de considerar sua participação no fenótipo como uma possibilidade. Estando ausentes o gene ZNF630 e parte do gene ZNF182 (afetando o transcrito ENST00000359880), ambos são candidatos, contribuindo para a deficiência mental, pois são expressos no cérebro e alguns representantes da família gênica já foram relacionados à deficiência mental.

No segmento em que a deleção está localizada, se conhecem variações de número de cópias em indivíduos clinicamente normais, o que torna complexa a relação dessa deleção com o fenótipo. Como em outras situações semelhantes, é possível que o fenótipo clínico dependa da associação da deleção com outra alteração genética. Uma associação 
casual não pode ser descartada. Diante disso, testamos a possibilidade de que a deficiência mental na família pudesse ser causada por mutação em gene não deletado co-segregando com a deleção: não detectamos alterações na região codificadora do gene ZNF81, já relacionado à deficiência mental e mapeado a $~ 32 \mathrm{~Kb}$ a 5' da deleção.

\section{Deleção do braço curto do cromossomo 8}

A Paciente 2 tem uma deleção no braço curto do cromossomo 8 [cariótipo 46,XX, $\operatorname{del}(8)(p 23)]$, que foi diagnosticada na análise cromossômica por bandamento GTG. Essa deleção está presente em seu pai, com quadro clínico semelhante. Os avós paternos da paciente têm cariótipos normais, sendo homozigóticos quanto a uma inversão de segmento que contém a deleção dos afetados e que é considerada polimórfica. Pela análise do locus de microssatélite D8S550 no pai e nos avós paternos da paciente, verificamos que a deleção ocorreu em um dos cromossomos 8 da avó. Os pontos das quebras cromossômicas que originaram a deleção foram mapeados usando-se FISH de segmentos clonados em BAC, delimitando-se um segmento deletado de cerca de 3,9 Mb, em 8p23.1. A análise in silico dos pontos de quebra mostrou a presença de sequiências de retrovírus endógenos humanos (HERV) do grupo E, com identidade de aproximadamente $90 \%$ nos segmentos dos pontos das quebras distal e proximal. Essas seqüências de identidade estão orientadas em sentidos opostos nas duas regiões dos pontos de quebra independentemente de estarem ou não em cromossomos portadores da inversão polimórfica. Nossa análise não identificou seqüências que indicassem que a homozigose quanto à inversão pudesse favorecer a ocorrência da deleção. A deleção pode ter sido gerada pelo pareamento intracromossômico entre duas dessas HERVE. 


\section{ABSTRACT}

Structural chromosomal alterations related to clinical phenotypes bring the opportunity to identify gene mutations determining the pathologies, because the causative genes may have been disrupted by the breaks or may have an altered number of copies. The delimitation of the segments involved in the chromosomal rearrangements is necessary for these genotype-phenotype correlations. The characterization of breakpoint and junction sequences in these chromosome alterations enables the identification of mechanisms originating them, and evidence has been produced pointing to the participation of particular genomic sequences in their formation. In this work, we studied two chromosomal deletions in patients with syndromic mental retardation, combining chromosomal analysis by fluorescent in situ hybridization (FISH) to DNA analysis. Our aim was to determine the mechanisms that originated these aberrations and how they were involved with the clinical phenotypes.

Patient 1, a boy with syndromic mental retardation, carried a microdeletion on the short arm of the $\mathrm{X}$ chromosome $[46, \mathrm{XY}, \operatorname{del}(\mathrm{X})(\mathrm{p} 11)]$ that was detected by comparative genome hybridization (CGH-array). Mental retardation in his family had an X-linked recessive pattern of inheritance. The deletion was detected in a maternal uncle of the propositus, who was similarly affected, and in heterozygosis in the patients' mothers. We delimited the deletion breakpoints by FISH of BAC clones: the deletion was mapped to adjacent BACs, which were partially deleted. Microsatellite genotyping contributed to refining breakpoint mapping. In silico analysis showed that the breakpoint-containing segments shared $\sim 16 \mathrm{~Kb}$ sequences with more than 95\% identity, which were $106 \mathrm{~Kb}$ apart from each other. With the collaboration of researchers from the Nijmegen Medical Centre, The Nederland, the presence and absence of segments from the two blocks could be further identified by SNPs. The proximal breakpoint could be mapped to a 1486 bp segment, and. the distal breakpoint to a 1292 bp segment, which shared 1189 bp of the repetition block, with $99 \%$ sequence identity. This segment includes the SPACA5 gene and the sequence immediately upstream of the $S P A C A 5 B$ gene. Non-allelic homologous recombination (NAHR) between these sequences could have given rise to the deletion. Four genes map to the deleted segment: SSX6, SPACA5, ZNF182 e ZNF630. However, this region has been 
described as including copy number variants, thus raising the possibility of a casual association of the deletion with the clinical phenotype. Alternatively a complex causative association may be present, as for example the dependence on another genetic alteration for the clinical manifestation.

Patient 2, a syndromic mentally retarded girl, carried a deletion on the short arm of chromosome 8 [46,XX, del(8)(p23)], which was diagnosed by GTG chromosome banding analysis. This deletion was inherited from her father, who presented with similar clinical features. Both paternal grandparents of the proposita had normal karyotypes, and microsatellite genotyping indicated that the deletion occurred on a grandmother's chromosome. The chromosomal breakpoints were mapped by FISH of BAC clones, which delimited the deleted segment to $\sim 3.9 \mathrm{Mb}$, in $8 \mathrm{p} 23.1$. Using a chromosome 8 tilepath microarray, the deletion was shown to be continuous. In silico analysis revealed the presence of human endogenous retrovirus (HERV) sequences of $E$ group, with 90\% identity in the proximal and distal breakpoint segments. These sequences were in opposite directions in the breakpoint regions, and their intrachromosomal pairing may have led to the deletion. By FISH analysis, the paternal grandparents were shown to be homozygous for a cryptic polymorphic inversion that included the deleted segment. We could not identify segments with high identity that had their direction changed by the inversion thus facilitating NAHR and the production of a $\sim 3.9 \mathrm{Mb}$ deletion. 


\section{REFERÊNCIAS BIBLIOGRÁFICAS}

Antonini, S.; Kim, C. H.; Sugayama, S. M.; Vianna-Morgante, A. M. - Delimitation of duplicated segments and identification of their parental origin in two partial chromosome $3 p$ duplications. Am J Med Genet 113(2): 144-150, 2002.

Bailey, J.A.; Yavor, A.M.; Massa, H.F.; Trask, B.J.; Eichler, E.E. - Segmental duplications: organization and impact within the current human genome project assembly. Genome Res 11(6): 1005-1017, 2001.

Bellefroid, E.J.; Poncelet, D.A.; Lecocq, P.J.; Revelant, O.; Martial, J.A. - The evolutionarily conserved Kruppel-associated box domain defines a subfamily of eukaryotic multifingered proteins. Proc Natl Acad Sci U S A. 88(9): 3608-12, 1991.

Bonnet, C.; Gregoire, M.J.; Brochet, K.; Raffo, E.; Leheup, B.; Jonveaux, P. - Pure de-novo 5 Mb duplication at Xp11.22-p11.23 in a male: phenotypic and molecular characterization. J Hum Genet.;51(9): 815-21, 2006.

Brooks, S.S.; Genovese, M.; Gu, H.; Duncan, C.J.; Shanske, A.; Jenkins, E.C. - Normal Adaptative Function With Learning Disability in Duplication 8p Including Band p22. Am J Med Genet 78(2): 114-117, 1998

Chen, Y.-T.; Iseli, C.; Venditti, C.A.; Old, L.J.; Simpson, A.J.G.; Jongeneel, C.V. - Identification of a new cancer/testis gene family, CT47, among expressed multicopy genes on the human X chromosome. Genes Chromosomes Cancer 45(4): 392-400, 2006.

Ciccone, R.; Giorda, R.; Gregato, G.; Guerrini, R.; Giglio, S.; Carrozzo, R.; Bonaglia, M.C.; Priolo, E.; Laganà, C.; Tenconi, R.; Rocchi, M.; Pramparo, T.; Zuffardi, O.; Rossi, E. - Reciprocal translocations: a trap for cytogenetists?. Hum Genet. 117(6): 571-82, 2005.

Ciccone, R.; Mattina, T.; Giorda, R.; Bonaglia, M.C.; Rocchi, M.; Pramparo, T.; Zuffardi, O. Inversion polymorphisms and non-contiguous terminal deletions: the cause and the (unpredicted) effect of our genome architecture. J Med Genet. 43(5):e19, 2006. 
Claeys, I.; Holvoet, M.; Eyskens, B.; Adriaensens, P.; Gewillig, M.; Fryns, J.P.; Devriendt, K. - A recognisable behavioural phenotype associated with terminal deletions of the short arm of chromosome 8. Am J Med Genet 74(5): 515-520, 1997.

de Vries, B.B.; Pfundt, R.; Leisink, M.; Koolen, D.A.; Vissers, L.E.; Janssen, I.M.; Reijmersdal, S.; Nillesen, W.M.; Huys, E.H.; Leeuw, N.; Smeets, D.; Sistermans, E.A.; Feuth, T.; van RavenswaaijArts, C.M.; van Kessel, A.G.; Schoenmakers, E.F.; Brunner, H.G.; Veltman, J.A. - Diagnostic genome profiling in mental retardation. Am J Hum Genet. 77(4): 606-16, 2005.

Devriendt, K.; Matthijs, G.; Van Dael, R.; Gewillig, M.; Eyskens, B.; Hjalgrim, H.; Dolmer, B.; McGaughran, J.; Bröndum-Nielsen, K.; Marynen, P.; Fryns, J.P.; Vermeesch, J.R. - Delineation of the Critical Deletion Region for Congenital Heart Defects, on Chromosome 8p23.1. Am J Hum Genet 64(4): 1119-1126, 1999.

Emanuel, B.S.; Shaikh, T.H. - Segmental duplications: an 'expanding' role in genomic instability and disease. Nat Rev Genet. 2(10): 791-800, 2001.

Endris, V.; Wogatzky, B.; Leimer, U.; Bartsch, D.; Zatyka, M.; Latif, F.; Maher, E.R.; Tariverdian, G.; Kirsch, S.; Karch, D.; Rappold, G.A. - The novel Rho-GTPase activating gene MEGAP/srGAP3 has a putative role in severe mental retardation. Proc Natl Acad Sci U S A. 99(18): 11754-11759, 2002.

Engelen, J.J.M.; de Die-Smulders, C.E.M.; Sijstermans, J.M.J.; Meers, L.E.C.; Albrechts, J.C.M.; Hamers, A.J.H. - Familial partial trisomy 8p without dysmorphic features and only mild mental retardation. J Med Genet 32(10): 792-795, 1995.

Floridia, G.; Piantanida, M.; Minelli, A.; Dellavecchia, C.; Bonaglia, C.; Rossi, E.; Gimelli, G.; Croci, G.; Franchi, F.; Gilgenkrantz, S.; Grammatico, P.; Dalpra, L.; Wood, S.; Danesino, C.; Zuffardi, O. - The same molecular mechanism at the maternal meiosis I produces mono- and dicentric 8p duplications. Am J Hum Genet. 58(4): 785-796, 1996.

Froyen, G.; Bauters, M.; Boyle, J.; Van Esch, H.; Govaerts, K.; van Bokhoven, H.; Ropers, H.H.; Moraine, C.; Chelly, J.; Fryns, J.P.; Marynen, P.; Gecz, J.; Turner, G. - Loss of SLC38A5 and 
FTSJ1 at Xp11.23 in three brothers with non-syndromic mental retardation due to a microdeletion in an unstable genomic region. Hum Genet. 121(5): 539-47, 2007.

Fryns, J.P.; Kleczkowska, A.; Vogels, A.; Van Den Berghe, H. - Normal phenotype and slight mental retardation in de novo distal 8p deletion (8pter $\rightarrow$ 8p23.1:). Ann Génét 32(3): 171-173, 1989.

Garg, V.; Kathiriya, I.S.; Barnes, R.; Schluterman, M.K.; King, I.N.; Butler, C.A.; Rothrock, C.R.; Eapen, R.S.; Hirayama-Yamada, K.; Joo, K.; Matsuoka, R.; Cohen, J.C.; Srivastava, D. - GATA4 mutations cause human congenital heart defects and reveal an interaction with TBX5. Nature 424(6947): 443-447, 2003.

Giglio, S.; Broman, K.W.; Matsumoto, N.; Calvari, V.; Gimelli, G.; Neumann, T.; Ohashi, H.; Voullaire, L.; Larissa, D.; Giorda, R.; Weber, J.L.; Ledbetter, D.H.; Zuffardi, O. - Olfactory receptor-gene clusters, genomic-inversion polymorphisms, and common chromosome rearrangements. Am J Hum Genet. 68(4): 874-83, 2001.

Gotter, A.L.; Nimmakayalu, M.A.; Jalali, G.R.; Hacker, A.M.; Vorstman, J.; Conforto Duffy, D.; Medne, L.; Emanuel, B.S. - A palindrome-driven complex rearrangement of 22q11.2 and 8q24.1 elucidated using novel technologies. Genome Res. 17(4): 470-81, 2007.

Gribble, S.M.; Prigmore, E.; Burford, D.C.; Porter, K.M.; Bee Ling Ng; Douglas, E.J.; Fiegler, H.; Carr, P.; Kalaitzopoulos, D.; Clegg, S.; Sandstrom, R.; Temple, I.K.; Youings, S.A.; Thomas, N.S.; Dennis, N.R.; Jacobs, P.A.; Crolla, J.A.; Carter, N.P.- The complex nature of constitutional de novo apparently balanced translocations in patients presenting with abnormal phenotypes. J Med Genet. 42(1): 8-16, 2005.

Güre, A.O.; Wei, I.J.; Old, L.J.; Chen, Y.T. - The SSX gene family: characterization of 9 complete genes. Int J Cancer. 101(5): 448-53, 2002.

Haber, J. E. - Partners and pathways repairing a double-strand break. Trends Genet.16(6): 259-64, 2000.

Hamel, B.C.J.; Smits, A.P.T.; van den Helm, B.; Smeets, D.F.C. M.; Knoers, N.V.A.M.; van Roosmalen, T.; Thoonen, G. H. J.; Assman-Hulsmans, C. F. C. H.; Ropers, H.-H.; Mariman, E. C. 
M.; Kremer, H. - Four families (MRX43, MRX44, MRX45, MRX52) with nonspecific X-linked mental retardation: clinical and psychometric data and results of linkage analysis. Am J Med Genet. 85(3): 290-304, 1999.

Hollox, E.J.; Armour, J.A.; Barber, J.C. - Extensive normal copy number variation of a betadefensin antimicrobial-gene cluster. Am J Hum Genet 73(3): 591-600, 2003.

Hughes, J.F.; Coffin, J.M. - Evidence for genomic rearrangements mediated by human endogenous retroviruses during primate evolution. Nat Genet 29(4): 487-489, 2001.

Jacobs, P.A.; Hassold, T.J. - Chromossome abnormalities: origin and etiology in abortions and livebirths. Human Genetics: Proceedings of the 7th International Congress: 234-244, 1986.

Kleefstra, T.; Yntema, H.G.; Oudakker, A.R.; Banning, M.J.G.; Kalscheuer, V.M.; Chelly, J.; Moraine, C.; Ropers, H.-H.; Fryns, J.-P.; Janssen, I.M.; Sistermans, E.A.; Nillesen, W.N.; de Vries, L.B.A.; Hamel, B.C.J.; van Bokhoven, H. - Zinc finger 81 (ZNF81) mutations associated with Xlinked mental retardation. (Letter) J. Med. Genet. 41(5): 394-399, 2004.

Klopocki, E.; Schulze, H.; Strauss, G.; Ott, C.E.; Hall, J.; Trotier, F.; Fleischhauer, S.; Greenhalgh, L.; Newbury-Ecob, R.A.; Neumann, L.M.; Habenicht, R.; König, R.; Seemanova, E.; Megarbane, A.; Ropers, H.H.; Ullmann, R.; Horn, D.; Mundlos, S. - Complex inheritance pattern resembling autosomal recessive inheritance involving a microdeletion in thrombocytopenia-absent radius syndrome. Am J Hum Genet. 80(2): 232-40, 2007.

Knijnenburg, J.; Szuhai, K.; Giltay, J.; Molenaar, L.; Sloos, W.; Poot, M.; Tanke, H.J.; Rosenberg, C. - Insights from genomic microarrays into structural chromosome rearrangements. Am J Med Genet 132A(1): 36-40, 2005.

Koolen, D.A.; Vissers, L.E.; Pfundt, R.; de Leeuw, N.; Knight, S.J.; Regan, R.; Kooy, R.F.; Reyniers, E.; Romano, C.; Fichera, M.; Schinzel, A.; Baumer, A.; Anderlid, B.M.; Schoumans, J.; Knoers, N.V.; van Kessel, A.G.; Sistermans, E.A.; Veltman, J.A.; Brunner, H.G.; de Vries, B.B. A new chromosome 17q21.31 microdeletion syndrome associated with a common inversion polymorphism. Nat Genet. 38(9): 999-1001, 2006. 
Krepischi-Santos, A.C.; Vianna-Morgante, A.M. - Disclosing the mechanisms of origin of de novo short-arm duplications of chromosome 9. Am J Med Genet A. 117(1): 41-6, 2003.

Krepischi-Santos, A.C.; Vianna-Morgante, A.M.; Jehee, F.S.; Passos-Bueno, M.R.; Knijnenburg, J.; Szuhai, K.; Sloos, W.; Mazzeu, J.F.; Kok, F.; Cheroki, C.; Otto, P.A.; Mingroni-Netto, R.C.; Varela, M.; Koiffmann, C.; Kim, C.A.; Bertola, D.R.; Pearson, P.L.; Rosenberg, C. - Wholegenome array-CGH screening in undiagnosed syndromic patients: old syndromes revisited and new alterations. Cytogenet Genome Res. 115(3-4): 254-61, 2006.

Lugtenberg, D, Yntema, H.G, Banning MJ, Oudakker AR, Firth HV, Willatt L, Raynaud M, Kleefstra T, Fryns JP, Ropers HH, Chelly J, Moraine C, Gecz J, Reeuwijk J, Nabuurs SB, de Vries BB, Hamel BC, de Brouwer AP, Bokhoven H. - ZNF674: A New Kruppel-Associated BoxContaining Zinc-Finger Gene Involved in Nonsyndromic X-Linked Mental Retardation. Am J Hum Genet. 78(2): 265-78, 2006.

Lukacsovich, T; Waldman, A.S. - Suppression of intrachromosomal gene conversion in mammalian cells by small degrees of sequence divergence. Genetics 151(4): 1559-1568, 1999.

Lupski, J.R. - Genome structural variation and sporadic disease traits. Nat Genet. 38(9): 974-6. 2006.

Lupski, J.R. - Genomic disorders: recombination-based disease resulting from genome architeture. Am J Hum Genet 72(2): 246-252, 2003.

Lupski, J.R. - Genomic disorders: structural features of the genome can lead to DNA rearrangements and human disease traits. Trends Genet 14(10): 417-422, 1998.

Moustacchi, E. - DNA damage and repair: consequences on dose-responses. Mutation Res. 464(1): 35-40, 2000.

Pehlivan, T.; Pober, B.R.; Brueckner, M.; Garrett, S.; Slaugh, R.; Rheeden, R.V.; Wilson, D.B.; Watson, M.S.; Hing, A. - GATA4 haploinsufficiency in patients with interstitial deletion of chromosome region 8p23.1 and congenital heart disease. Am J Hum Genet 83(3): 201-206, 1999. 
Petek, E.; Windpassinger, C.; Vincent, J.B.; Cheung, J.; Boright, A.P.; Scherer, S.W.; Kroisel, P.M.; Wagner, K. - Disruption of a novel gene $(I M M P 2 L)$ by a breakpoint in $7 \mathrm{q} 31$ associated with Tourette syndrome. Am J Hum Genet. 68(4): 848-858, 2001.

Pierpont, M.E.; Markwald, R.R.; Lin, A.E. - Genetic aspects of atrioventricular septal defects. Am J Med Genet 97(4): 289-296, 2000.

Redon, R.; Ishikawa, S.; Fitch, K.R.; Feuk, L.; Perry, G.H.; Andrews, T.D.; Fiegler, H.; Shapero, M.H.; Carson, A.R.; Chen, W.; Cho, E.K.; Dallaire, S.; Freeman, J.L.; Gonzalez, J.R.; Gratacos, M.; Huang, J.; Kalaitzopoulos, D.; Komura, D.; Macdonald, J.R.; Marshall, C.R.; Mei, R.; Montgomery, L.; Nishimura, K.; Okamura, K.; Shen, F.; Somerville, M.J.; Tchinda, J.; Valsesia, A.; Woodwark, C.; Yang, F.; Zhang, J.; Zerjal, T.; Zhang, J.; Armengol, L.; Conrad, D.F.; Estivill, X.; Tyler-Smith, C.; Carter, N.P.; Aburatani, H.; Lee, C.; Jones, K.W.; Scherer, S.W.; Hurles, M.E. Global variation in copy number in the human genome. Nature. 444(7118): 444-54, 2006.

Robinson, S.W.; Morris, C.D.; Goldmuntz, E.; Reller, M.D.; Jones, M.A.; Steiner, R.D.; Maslen, C.L. - Missense mutations in CRELD1 are associated with cardiac atrioventricular septal defects. Am J Hum Genet 72(4): 1047-1052, 2003.

Rosenberg, C.; Knijnenburg, J.; Bakker, E.; Vianna-Morgante, A.M.; Sloos, W.; Otto, P.A.; Kriek, M.; Hansson, K.; Krepischi-Santos, A.C.; Fiegler, H.; Carter, N.P.; Bijlsma, E.K.; van Haeringen, A.; Szuhai, K.; Tanke, H.J. - Array-CGH detection of micro rearrangements in mentally retarded individuals: clinical significance of imbalances present both in affected children and normal parents. J Med Genet. 43(2): 180-6, 2006.

Rosenberg, C.; Knijnenburg, J.; Clauffailla Mde, L.; Brunoni, D.; Catelani, A.L.; Sloos, W.; Szuhai, K.; Tanke, H.J. - Array CGH detection of a cryptic deletion in a complex chromosome rearrangement. Hum Genet. 116(5): 390-4, 2005.

Shaffer, L.G.; Lupski, J.R. - Molecular mechanisms for constitutional chromosomal rearrangements in humans. Annu Rev Genet. 34: 297-329, 2000. 
Shaikh, T.H.; Kurahashi, H.; Emanuel, B.S. - Evolutionarily conserved low copy repeats (LCRs) in 22q11 mediate deletions, duplications, translocations, and genomic instability: an update and literature review. Genet Med. 3(1): 6-13, 2001.

Sharp, A.J.; Hansen, S.; Selzer, R.R.; Cheng, Z.; Regan, R.; Hurst, J.A.; Stewart, H.; Price, S.M.; Blair, E.; Hennekam, R.C.; Fitzpatrick, C.A.; Segraves, R.; Richmond, T.A.; Guiver, C.; Albertson, D.G.; Pinkel, D.; Eis, P.S.; Schwartz, S.; Knight, S.J.; Eichler, E.E. - Discovery of previously unidentified genomic disorders from the duplication architecture of the human genome. Nat Genet. 38(9): 1038-42, 2006.

Sharp, A.J.; Locke, D.P.; McGrath, S.D.; Cheng, Z.; Bailey, J.A.; Vallente, R.U.; Pertz, L.M.; Clark, R.A.; Schwartz, S.; Segraves, R.; Oseroff, V.V.; Albertson, D.G.; Pinkel, D.; Eichler, E.E. Segmental duplications and copy-number variation in the human genome. Am J Hum Genet. 77(1): 78-88, 2005.

Shaw, C.J.; Lupski, J.R. - Implications of human genome architecture for rearrangement-based disorders: the genomic basis of disease. Hum Mol Genet. 13, Rev Issue 1: R57-64, 2004.

Shaw, C.J.; Withers, M.A.; Lupski, J.R. - Uncommon deletions of the Smith-Magenis syndrome region can be recurrent when alternate low-copy repeats act as homologous recombination substrates. Am J Hum Genet. 75(1): 75-81, 2004.

Shaw-Smith, C.; Pittman, A.M.; Willatt, L.; Martin, H.; Rickman, L.; Gribble, S.; Curley, R.; Cumming, S.; Dunn, C.; Kalaitzopoulos, D.; Porter, K.; Prigmore, E.; Krepischi-Santos, A.C.; Varela, M.C.; Koiffmann, C.P.; Lees, A.J.; Rosenberg, C.; Firth, H.V.; de Silva, R.; Carter, N.P. Microdeletion encompassing MAPT at chromosome 17q21.3 is associated with developmental delay and learning disability. Nat Genet. 38(9): 1032-7, 2006.

Stankiewicz, P.; Lupski, J.R. Genome Architecture, rearrangements and genomic disorders. Trends Genet 18(2): 74-82, 2002.

Stankiewicz, P.; Shaw, C.J.; Dapper, J.D.; Wakui, K.; Shaffer, L.G.; Withers, M.; Elizondo, L.; Park, S.S.; Lupski, J.R. - Genome architecture catalyzes nonrecurrent chromosomal rearrangements. Am J Hum Genet. 72(5): 1101-1116, 2003. 
Strout, M.P.; Marcucci, G.; Bloomfield, C.D.; Caligiuri, M.A. - The partial tandem duplication of ALL1 (MLL) is consistently generated by Alu-mediated homologous recombination in acute myeloid leukemia. Proc Natl Acad Sci U S A. 95(5): 2390-5, 1998.

Sugawara, H.; Harada, N.; Ida, T.; Ishida, T.; Ledbetter, D.H.; Yoshiura, K.; Ohta, T.; Kishino, T.; Niikawa, N.; Matsumoto, N. - Complex low-copy repeats associated with a common polymorphic inversion at human chromosome 8p23. Genomics. 82(2): 238-44, 2003.

Sverdlov, E.D. - Retroviruses and primate evolution. Bioessays. 22(2): 161-71. Review. 2000.

Ullmann, R.; Turner, G.; Kirchhoff, M.; Chen, W.; Tonge, B.; Rosenberg, C.; Field, M.; ViannaMorgante, A.M.; Christie, L.; Krepischi-Santos, A.C.; Banna, L.; Brereton, A.V.; Hill, A.; Bisgaard, A.M.; Müller, I.; Hultschig, C.; Erdogan, F.; Wieczorek, G.; Ropers, H.H. - Array CGH identifies reciprocal 16p13.1 duplications and deletions that predispose to autism and/or mental retardation. Hum Mutat. 28(7): 674-682, 2007.

van Bakel, I.; Holt, S.; Craig, I.; Boyd, Y. - Sequence analysis of the breakpoint regions of an X;5 translocation in a female with Duchenne muscular dystrophy. Am J Hum Genet. 57(2): 329-336, 1995.

Varela, M.C.; Krepischi-Santos, A.C.; Paz, J.A.; Knijnenburg, J.; Szuhai, K.; Rosenberg, C.; Koiffmann, C.P. - A 17q21.31 microdeletion encompassing the MAPT gene in a mentally impaired patient. Cytogenet Genome Res. 114(1): 89-92, 2006.

Vianna-Morgante, A.M.; Kerkis, I.E.; Krepischi-Santos, A.C.V. - Sequencing of the breakpoint junction fragments of an X;autosome translocation in a female with Duchenne muscular dystrophy. The American Society of Human Genetics. 54 ${ }^{\text {th }}$ Annual Meeting. Toronto, Canada. 947/W, 2004.

Wong, K.K.; deLeeuw, R.J.; Dosanjh, N.S.; Kimm, L.R.; Cheng, Z.; Horsman, D.E.; MacAulay, C.; Ng, R.T.; Brown, C.J.; Eichler, E.E.; Lam, W.L. - A comprehensive analysis of common copynumber variations in the human genome. Am J Hum Genet. 80(1): 91-104, 2007. 
Yenamandra, A.; Perrone, R.; McLaughlin, J.; Mehta, L. - Inverted Duplication/Deletion of Chromosome 8p: Mild Clinical Phenotype. Am J Med Genet 82(1): 91-93, 1999.

\section{BANCOS DE DADOS ELETRÔNICOS E OUTROS RECURSOS DA INTERNET}

CHORI (Children's Hospital Oakland Research Institute)

http://www.chori.org

Database of Genomic Variants (atualizado em 11 de outubro de 2006)

http://projects.tcag.ca/variation/

Ensembl

http://www.ensembl.org

GeneCard database

www.genecards.org

Genome Database (GDB)

http://gdbwww.gdb.org

IDT

http://www.idtdna.com/Home/Home.aspx

Mammalian Genotyping Service (The National Heart, Lung, and Blood Institute)

http://research.marshfieldclinic.org/genetics/home/index.asp

NCBI (National Center for Biotechnology Information)

http://www.ncbi.nlm.nih.gov

Primer3

http://frodo.wi.mit.edu/

The Centre for Applied Genomics (build 36, March 2006)

http://www.projects.tcag.ca/variation/

UCSC (University of California - Santa Cruz) Genome Browser - Mar. 2006 Assembly http://genome.ucsc.edu

UniProt

http://www.ebi.uniprot.org/index.shtml

Webcutter 2.0

http://rna.lundberg.gu.se/cutter2 